\title{
River Protection Project - Project Management Plan
}

Prepared for the U.S. Department of Energy

Assistant Secretary for Environmental Management

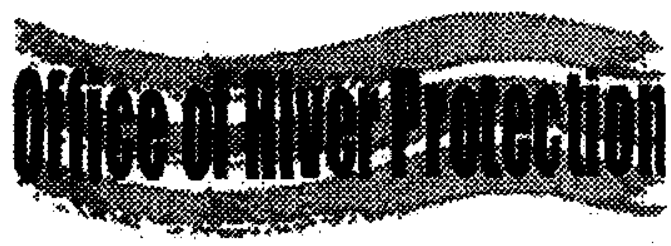

P.O. Box 450

Richland, Washington 99352 


\section{LEGAL DISCLAIMER}

This report was prepared as an account of work sponsored by an agency of the United States Government. Neither the United States Government nor any agency thereol, nor any of their employees, nor any of their contractors, subcontractors or their employees, makes any warranty, express or implied, or assumes any legal liability or responsibility for the accuracy, completeness, or any third party's use or the results of such use of any information, apparatus, product, or process disclosed, or represents that its use would not infringe privately owned rights. Reference herein to any specific commercial product, process, or service by trade name, trademark, manufacturer, or othenwise, does not necessarily constitute or imply its endorsement, recommendation, or favoring by the United States Government or any agency thereot or its contractors or subcontractors. The views and opinions of authors expressed herein do not necessarily state or reflect those of the United States Government or any agency thereof.

This report has been reproduced from the best available copy. 


\section{RELEASE AUTHORIZATION}

Document DOE/ORP-2000-06, Rev.0

Number:

Document Title: $\quad$ River Protection Project - Project Management Plan

\section{This document, reviewed in accordance with DOE Order 241.1, "Scientific and Technical Information Management," and DOE G 241.1-1, "Guide to the Management of Scientific and Technical lnformation," does not contain classified or sensitive unclassified information and is:}

\section{APPROVED FOR PUBLIC RELEASE}

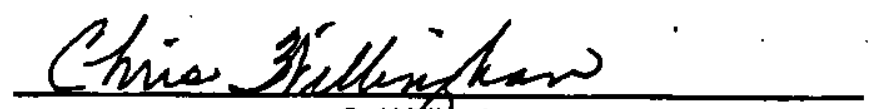

$4 / 20 / 00$

C. Whingham

Lockheed Martin Services, Inc.

Document Control/Information Clearance

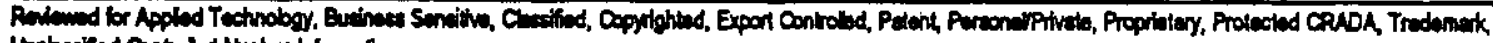

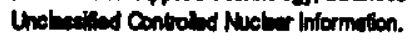

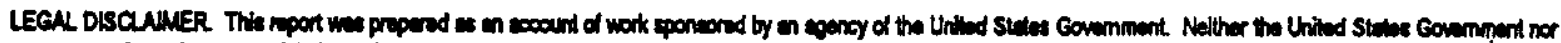

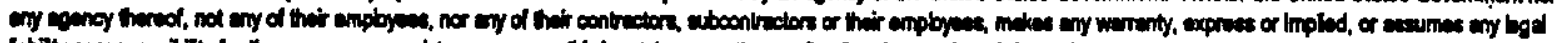

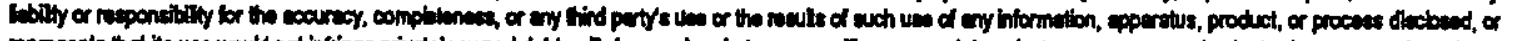

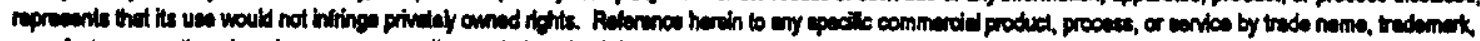

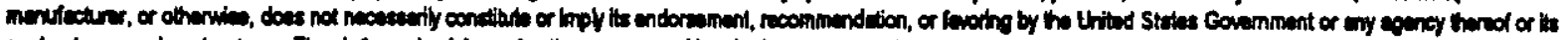

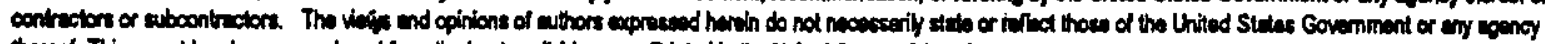

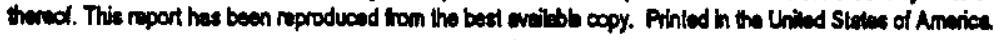




\section{INFORMATION CLEARANCE FORM}

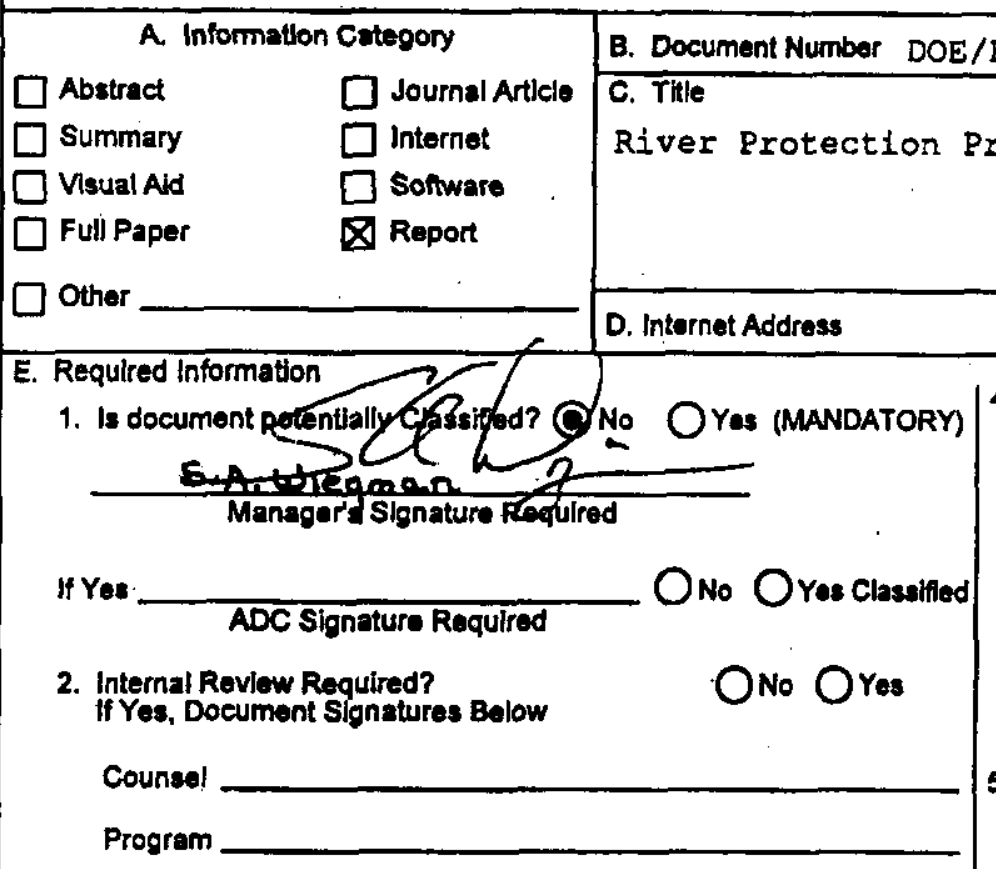

3. References in the Information are Applied Tochnology ONo OYes Export Controllod Information ONo OYes

4. Does Information Contain the Following: (MANDATORY)

a. New or Novel (Patentable) Subject Matter? ONo OYes If "Yes", Disclosure No.:

b. Information Recelved in Confidence, Such as Proprletary and/or Inventions? ONo OYes If "Yes", Affix Appropriate Legends/Nollces.
c. Copyrights? $\mathrm{ONo}$
OYes
If "Yes". Attech Permission.
d. Trademarks?
ONo
OYes
If "Yes", Identify in Document.

5. Is Information requiring submlssion to OST!? $\quad$ No $O$ Yes If Yes UCand $B \in R-$

\section{Release Level? $\bigcirc$ Public $\bigcirc$ Limited}

7. Charge Code

F. Complote for a Journal Article

1. Title of Journal

G. Complote for a Presentation

1. Title for Conference or Meeting

2. Group Sponsoring

3. Date of Conference

4. City/Stato

5. Will information be Publishegth Proceedings? $O$ No OYes

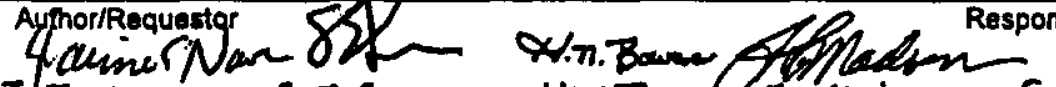

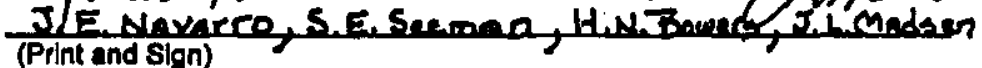

I. Reviewers Yes Print

General Counsel

$\square$

Office of External Affairs DOE-NLORP :

Other S.D. Stubblebine. L. E. Love Other S.A Wiegman S.A. Print and (Print ang 8 ign

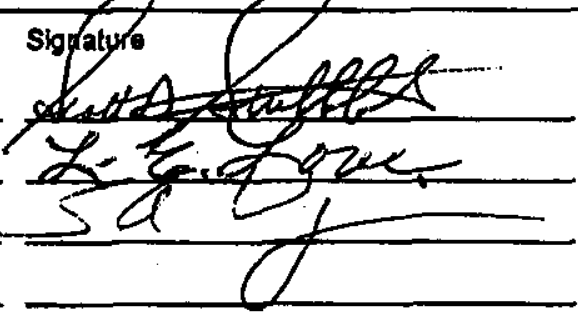

Public Y/N (If N, complete J)

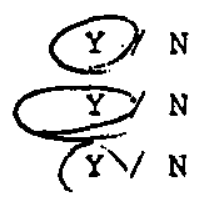

$Y / N$

$Y / N$

J. If Information Includes Sensitive Information and is not to be released to the Public indleate category below.
$\square$ Applied Technology .
$\square$ Protected CRADA
$\square$ Personaliprivate
$\square$ Export Controlled
$\square$ Proprietary
$\square$ Business-Sensitive
$\square$ Procurement-Sensitive
$\square$ Predecislonal
$\square$ Patentable
$\square$ UCNI
$\square$ Other (Specify)

K. If Additional Comments, Please Attach Separate Sheet 
DOE/ORP-2000-06

Revision 0

\section{River Protection Project - Project Management Plan}

Date Published

April 2000

Prepared for the U.S. Department of Energy Assistant Secretary for Environmental Management

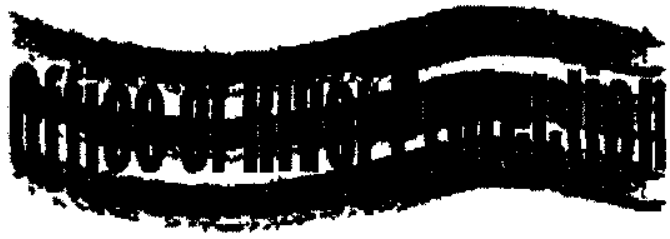

P.O. Box 450

Richland, Washington 99352 
DOE/ORP-2000-06

Rev. 0

This page intentionally left blank. 
DOE/ORP-2000-06

Rev. 0

RIVER PROTECTION PROJECT - PROJECT MANAGEMENT PLAN
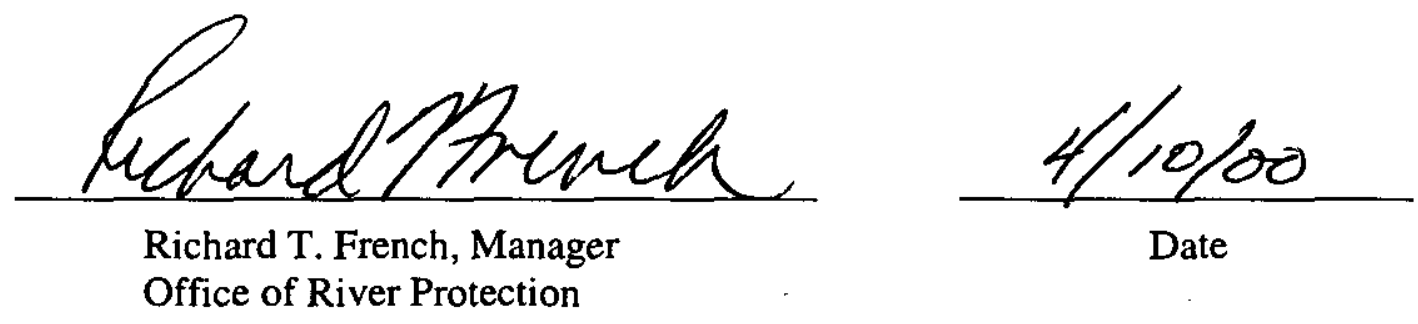

iii 
DOE/ORP-2000-06

Rev. 0

This page intentionally left blank. 


$$
8
$$


DOE/ORP-2000-06

Rev. 0

- It lays out the plan and tools to integrate government, contractors, and regulators into one integrated team.

- It provides an appropriate focus on quality and safety.

The PMP describes how the ORP and its contractors manage the RPP as an integrated project. The primary focus is on the ORP organization and management processes, but this PMP also references management documents of the current ORP Prime Contractors and the Hanford Site Management and Integration Contractor.

Management of the RPP is presented as the structure depicted in Figure ES-2. The RPP must address strategic management, baseline management, and work management. Shown above the management layers are the external drivers. Between baseline and work management are the contracts that define and control the work of the contractors.

Figure ES-2. River Protection Project Management Structure.

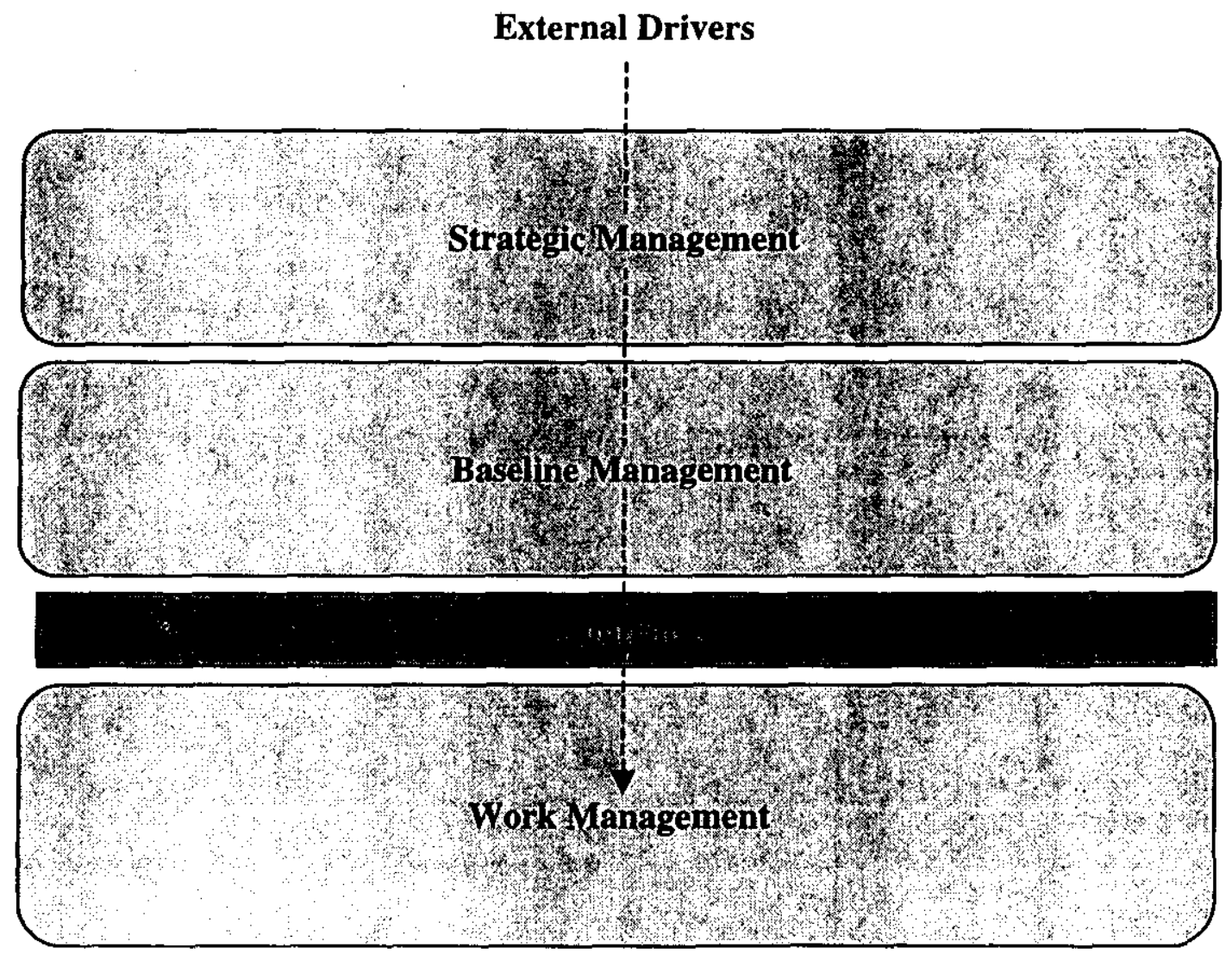


DOE/ORP-2000-06

Rev. 0

External drivers represent the ORP interfaces with external requirements and policy sources such as the U.S. Department of Energy-Headquarters and the regulatory agencies. The RPP is conducted in compliance with external requirements, such as laws, regulations, and U.S. Department of Energy Orders (e.g., DOE O 435.1, Radioactive Waste Management).

Strategic management is within the ORP, and is directly managed by the Manager, ORP. It receives the external drivers and develops the documents (e.g. DOE/ORP-2000-09, River Protection Project Strategic Plan and DOE/ORP-2000-10, River Protection Project Mission Analysis Report), policies, etc., that become requirements and guidance to lower management layers.

Baseline management is internal to the ORP, and "maintains the course" of the RPP. This includes planning, budgeting, control, and evaluation functions.

Contracts are the mechanisms with which the ORP manages its contractors. The contracts pass to the contractors the description of the work and the specifications and requirements for the work.

Work management is the responsibility of the RPP contractors and "accomplishes the work."

This PMP describes the project, its organization, baseline, and major processes used to manage the RPP. Management processes are described with respect to how they are implemented within the project management structure described above. Many of the subsections of the PMP use Figure ES-2 to describe the management process in more detail. The major drivers, how the process is accomplished, and resulting products are then placed onto the diagram as appropriate. This provides a process and document hierarchy for each of the management processes.

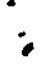


DOE/ORP-2000-06

Rev. 0

The PMP is organized into seven sections:

- Introduction provides an overview of the PMP.

- Project Description discusses the general background, mission, scope, and key planning assumptions of the RPP.

- Organization and Responsibilities portrays the organization, responsibilities, and organizational interfaces of the RPP.

- Project Baseline describes the integrated baseline, shows the work breakdown structure and overall logic of the project, and summarizes the baseline cost and schedule.

- Project Control describes the management systems used to control the RPP, including systems engineering, configuration management, baseline change control, contract management, performance measurement, information and reporting, interface management, work authorization, work management, risk management, construction project management, and communications and stakeholder/public involvement.

- Compliance describes how the Integrated Safety Management System is set up to ensure environmental management, occupational safety and health, nuclear safety, and radiological safety. It also describes the management of quality assurance, emergency management, and safeguards and security.

- References contains a reference listing of all documents called out in this PMP. 


\section{CONTENTS}

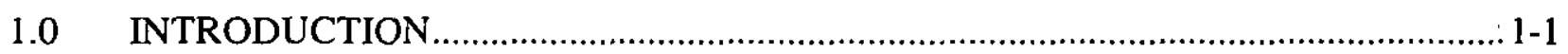

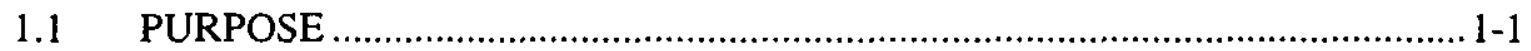

1.2 PROJECT MANAGEMENT STRUCTURE ……....................................1-2

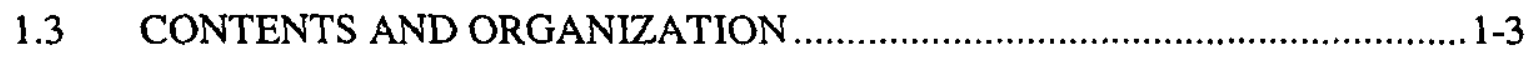

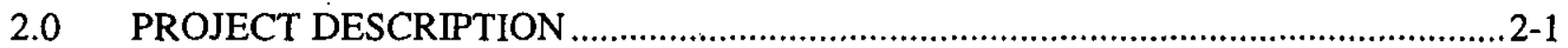

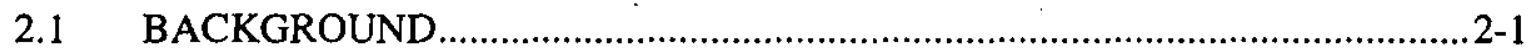

2.2 RIVER PROTECTION PROJECT MISSION AND SCOPE.............................2-1

2.3 KEY PLANNING ASSUMPTIONS ……….............................................2-4

3.0 ORGANIZATION AND RESPONSIBILITIES ........................................................

3.1 RIVER PROTECTION PROJECT ORGANIZATION AND RESPONSIBILITIES ...............................................................................

3.2 OFFICE OF RIVER PROTECTION ORGANIZATION AND

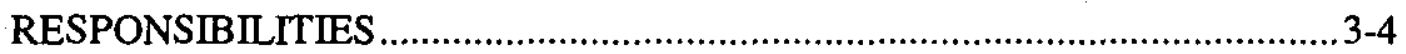

3.3 ORGANIZATIONAL INTERFACES .......................................................

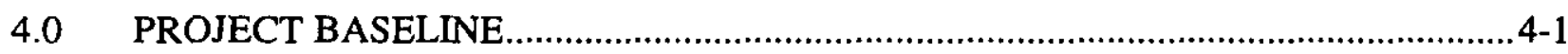

$4.1 \quad$ INTEGRATED BASELINE DEFINITION ...................................................

4.2 TECHNICAL BASELINE ......................................................................

4.3 DOCUMENT HIERARCHY ...................................................................

4.4 WORK BREAKDOWN STRUCTURE ..................................................

4.5 RIVER PROTECTION PROJECT LOGIC ................................................ 4-9

4.6 BASELINE SCHEDULE AND COST SUMMARY ........................................ 4-13

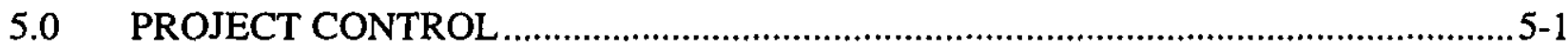

5.1 SYSTEMS ENGINEERING MANAGEMENT ..........................................5-1

5.2 CONFIGURATION MANAGEMENT ………............................................. 5-3

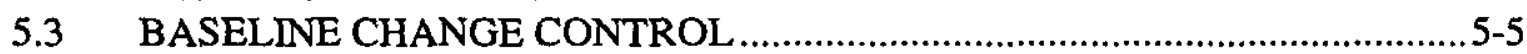

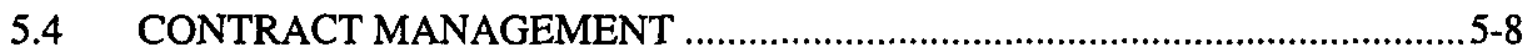

5.5 PERFORMANCE MEASUREMENT ……...........................................5-10

5.6 INFORMATION AND REPORTING ……….....................................

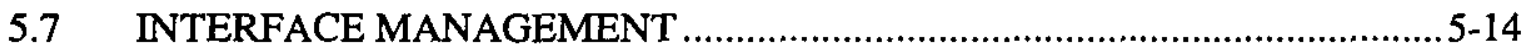

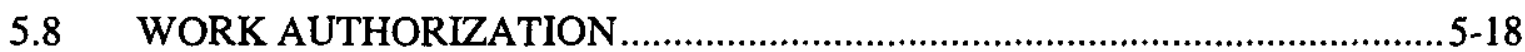

5.9 WORK MANAGEMENT ...................................................................... 5-19

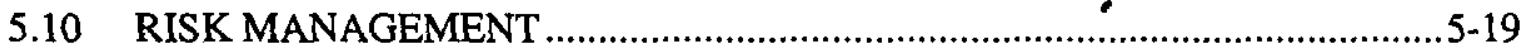

5.11 CONSTRUCTION PROJECT MANAGEMENT ……..................................5-21

5.11.1 Project Baseline and Contract Management ....................................5-21

5.11.2 Construction Project Work Management ..............................................5-22

5.12 COMMUNICATIONS AND STAKEHOLDER/PUBLIC

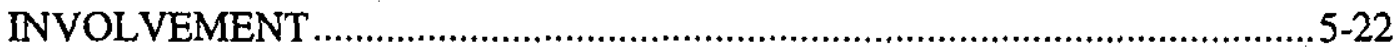

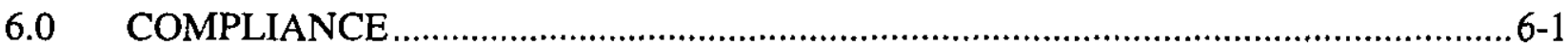

6.1 INTEGRATED SAFETY MANAGEMENT .............................................6-1 
DOE/ORP-2000-06

Rev. 0

6.1.1 Environmental Management ....................................................6-4

6.1.2 Occupational Safety and Health .....................................................6

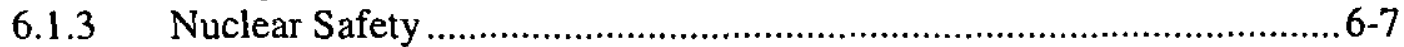

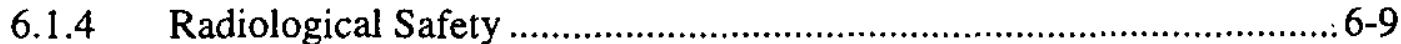

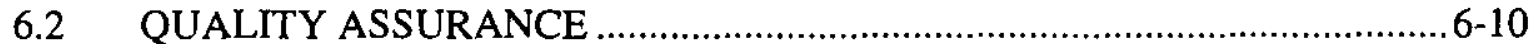

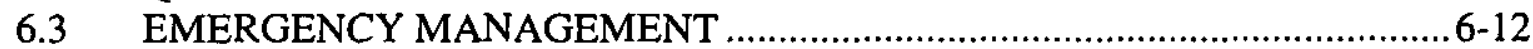

6.4 SAFEGUARDS AND SECURITY .................................................... 6-14

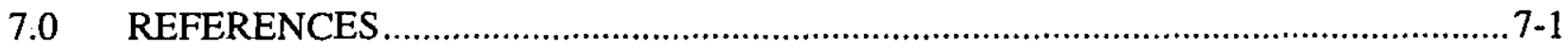

\section{LIST OF FIGURES}

Figure 1-1. The River Protection Project Team........................................................... 1-1

Figure 1-2. River Protection Project Management Structure ............................................ 1-2

Figure 2-1. River Protection Project Mission..............................................................2-2

Figure 3-1. Organizational Relationships for Office of River Protection............................. 3-1

Figure 3-2. Organization Chart for Office of River Protection............................................3-5

Figure 4-1. Integrated Baseline Development Document Hierarchy and Process....................4-2

Figure 4-2. Technical Baseline Document Hierarchy and Process...................................4-4

Figure 4-3. Office of River Protection Document Hierarchy...........................................4-6

Figure 4-4. River Protection Project Work Breakdown Structure. ........................................4-8

Figure 4-5. River Protection Project Mission Logic. .................................................. 4-11

Figure 4-6. Management Summary Schedule............................................................... 4-15

Figure 5-1. Systems Engineering Documents, Process, and Products....................................5-2

Figure 5-2. Configuration Management Document Hierarchy and Process............................5-4

Figure 5-3. Change Control Document Hierarchy and Frocess.......................................5-6

Figure 5-4. Contract Management Document Hierarchy and Process.................................. 5-9

Figure 5-5. Performance Measurement Process......................................................... 5-11

Figure 5-6. Information and Reporting Document Hierarchy and Process...........................5-13

Figure 5-7. Office of River Protection Interfaces. .................................................... $5-15$ 
DOE/ORP-2000-06

Rev. 0

Figure 5-8. Integrated Product/Process Teams.

Figure 5-9. Interface Control Documents.

Figure 5-10. Work Authorization Document Hierarchy and Process.

Figure 5-11. Risk Management Document Hierarchy and Process.

Figure 5-12. Communications Hierarchy.

Figure 6-1. Integrated Safety Management Document Hierarchy.

Figure 6-2. Environmental Document Hierarchy

Figure 6-3. Occupational Safety and Health Document Hierarchy. 6-6

Figure 6-4. Nuclear Safety Document Hierarchy. $6-8$

Figure 6-5. Radiological Safety Document Hierarchy. 6-10

Figure 6-6. Quality Assurance Document Hierarchy. 6-11

Figure 6-7. Emergency Management Document Hierarchy. 6-13

Figure 6-8. Safeguards and Security Document Hierarchy. 6-15

\section{LIST OF TABLES}

Table 4-1. Cost Summaries (dollars in millions). 4-14 
DOE/ORP-2000-06

Rev. 0

This page intentionally left blank. 


\section{LIST OF TERMS}

$\mathrm{AB}$

ACTR

AE Act

BCR

BNFL

CCB

$\mathrm{CFO}$

$\mathrm{CHG}$

$\mathrm{CM}$

CWC

D\&D

DEAR

DNFSB

DOE

DOE-EM

DOE-HQ

DOE-RW

DST

Ecology

EIS

EPA

ER

ES\&H

ESH\&Q

ETF

FRAM

FY

GAO

HLW

ICD

ID

IHLW

ILAW

IPABS

IPPD.

IPT

IRM

ISM

ISSTRS

LAW

MOA

MOU

MUST
Authorization Basis

acquire commercial technology for retrieval

Atomic Energy Act of 1954

Baseline Change Request

BNFL Inc.

Change Control Board

Chief Financial Officer

CH2M HILL Hanford Group, Inc.

configuration management

Central Waste Complex

decontaminate and decommission

Department of Energy Acquisition Regulation

Defense Nuclear Facilities Safety Board

U.S. Department of Energy

U.S. Department of Energy, Office of Environmental Management

U.S. Department of Energy-Headquarters

U.S. Department of Energy, Office of Civilian Radioactive Waste

Management

double-shell tank

Washington State Department of Ecology

Environmental Impact Statement

U.S. Environmental Protection Agency

Environmental Restoration

Environmental, Safety and Health

Environment, Safety, Health and Quality

Effluent Treatment Facility

Functions, Responsibilities, and Authorities Manual

fiscal year

General Accounting Office

high-level waste

interface control document

interface description

immobilized high-level waste

immobilized low-activity waste

Integrated Planning, Accountability, and Budgeting System

integrated product and process development

Integrated Product/Process Team

Information Resource Management

Integrated Safety Management

Initial Single-Shell Tank Retrieval System

low-activity waste

Memorandum of Agreement

Memorandum of Understanding

miscellaneous underground storage tank 
DOE/ORP-2000-06

Rev. 0

MYWP

NEPA

ORP

OSH

Pacific Northwest

PBS

PC

PER

PH

PHMC

PIO

PMP

QA

QAP

RCRA

RL

ROD

RPP

SAS

SE

SEMP

SRID

SSSTRS

SST

TEDF

TFC

TPA

TWRS

TWRS-P

USQ

WBS

WDD
Multi-Year Work Plan

National Environmental Policy Act of 1969

Office of River Protection

Occupational Safety and Health

Pacific Northwest National Laboratory

project baseline summary

Privatization Contractor

Environmental Permitting

Project Hanford

Project Hanford Management Contract

Project Integration Office

Project Management Plan

Quality Assurance

Quality Assurance Plan

Resource Conservation and Recovery Act of 1976

U.S. Department of Energy, Richland Operations Office

Record of Decision

River Protection Project

Safeguards and Security

systems engineering

Systems Engineering Management Plan

Standards/Requirements Identification Document

Subsequent Single-Shell Tank Retrieval System

single-shell tank

Treated Effluent Disposal Facility

Tank Farm Contractor

Tri-Party Agreement (Hanford Federal Facility Agreement and Consent Order)

Tank Waste Remediation System

Tank Waste Remediation System-Privatization

Unreviewed Safety Question

work breakdown structure

Waste Disposal Division 
DOE/ORP-2000-06

Rev. 0

\section{RIVER PROTECTION PROJECT - PROJECT MANAGEMENT PLAN}

\subsection{INTRODUCTION}

The U.S. Department of Energy (DOE), in accordance with the Strom Thurmond National Defense Authorization Act for Fiscal Year 1999, established the Office of River Protection (ORP) to successfully execute and manage the River Protection Project (RPP), formerly known as the Tank Waste Remediation System (TWRS). The mission of the RPP is to store, retrieve, treat, and dispose of the highly radioactive Hanford tank waste in an environmentally sound, safe, and cost-effective manner.

The team shown in Figure $1-1$ is accomplishing the project. The ORP is providing the management and integration of the project; the Tank Farm Contractor (TFC) is responsible for providing tank waste storage, retrieval, and disposal; and the Privatization Contractor (PC) is responsible for providing tank waste treatment.

Figure 1-1. The River Protection Project Team.

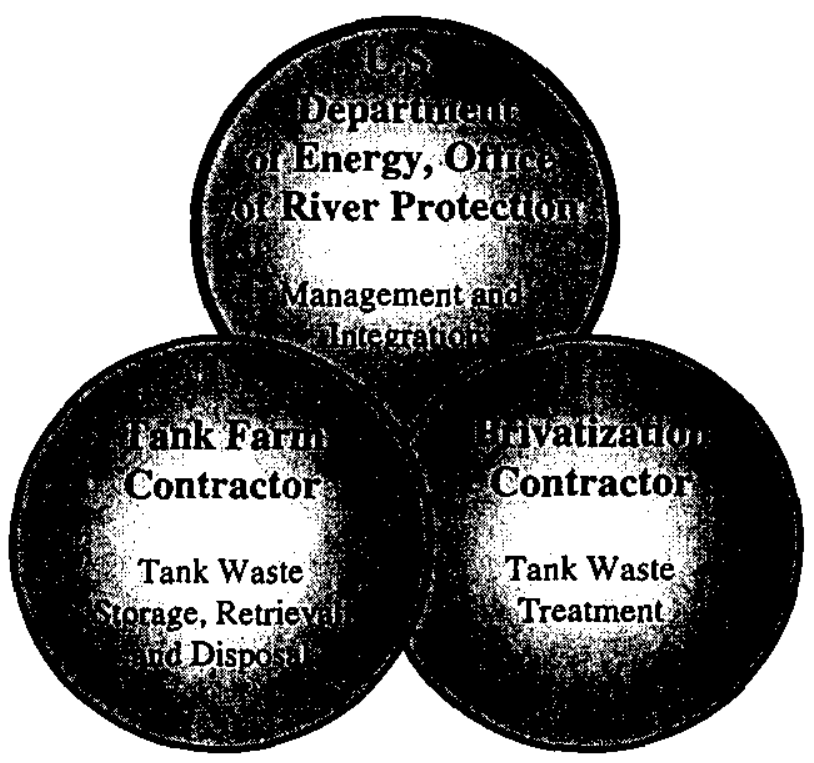

\subsection{PURPOSE}

This Project Management Plan (PMP) describes how the ORP and its contractors manage the RPP as an integrated project. The primary focus is on the ORP organization and management processes, but the PMP also references management documents of the ORP Prime Contractors (the TFC and the PC) and the Hanford Site Management and Integration Contractor. 


\section{DOE/ORP-2000-06 \\ Rev. 0}

The PMP is consistent with the guidance provided in DOE O 430.1A, Life Cycle Asset Management and associated Good Practice Guide GPG-FM-010, Project Execution and Engineering Management Planning. It also considers the guidance provided in the DOE EM Privatization Program Management Plan.

\subsection{PROJECT MANAGEMENT STRUCTURE}

Management of the RPP can be viewed as the structure depicted in Figure 1-2. The RPP must address three layers: strategic management, baseline management, and work management. Shown above the management layers are the external drivers. Between baseline and work management are the contracts that define and control the work of the contractors.

Figure 1-2. River Protection Project Management Structure.

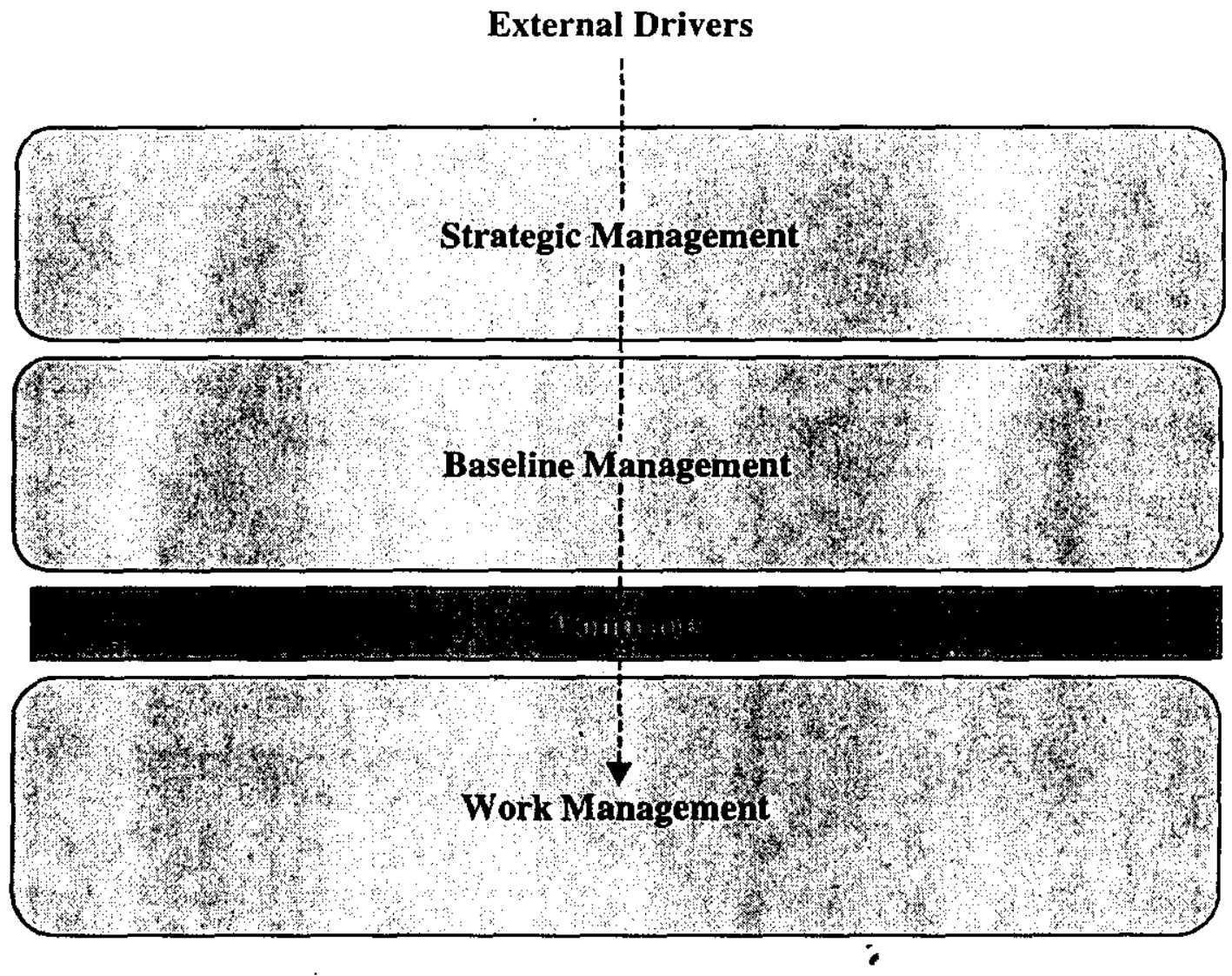

External drivers represent the ORP interfaces with external requirements and policy sources such as the U.S. Department of Energy-Headquarters (DOE-HQ) and the regulatory agencies. The RPP is conducted in compliance with external requirements, such as laws, regulations, and DOE Orders (e.g., DOE O 435.1, Radioactive Waste Management). 
Strategic management is within the ORP, and is directly managed by the Manager, ORP. It receives the external drivers and develops the documents (e.g., DOE/ORP-2000-09, River Protection Project Strategic Plan and DOE/ORP-2000-10, River Protection Project Mission Analysis Report), policies, etc., that become requirements and guidance to lower management layers. It includes the following tasks:

- Establish the RPP vision and strategy for accomplishing the mission.

- Establish strategic project milestones and decision points.

- Organize to achieve the strategy.

- Establish the overall RPP management processes.

- Assess RPP risk and effectiveness.

- Manage change during the RPP life-cycle process.

Baseline management is internal to the ORP, and "maintains the course" of the RPP. This includes planning, budgeting, control, and evaluation functions and the following tasks:

- Establish and maintain the integrated baseline to accomplish the mission.

- Establish and manage baseline change control.

- Integrate project management across organizations.

- Acquire and allocate resources.

- Establish and manage contracts and agreements.

- Provide administrative, business, and regulatory compliance management.

- Authorize work.

- Establish safety requirements.

- Monitor the status of work and incurred costs.

- Assess participant performance.

- Minimize and manage risks.

- Manage communications with the public and stakeholders.

Contracts are the mechanisms with which the ORP manages its contractors. The contracts pass to the contractors the description of, and the requirements and specifications for, the work.

Work management is the responsibility of the RPP contractors and "accomplishes the work." It includes, but is not limited to, the following tasks:

- Design and construct facilities and equipment.

- Perform operations and maintenance.

- Manage work interfaces.

- Perform operations and facility evaluations.

- Maintain configuration management (CM).

- Ensure work is performed safely and within regulatory requirements.

\subsection{CONTENTS AND ORGANIZATION}

The PMP describes the project, its organization, baseline, and major processes used to manage the RPP. Management processes are described with respect to how they are implemented within the project management structure described in Section 1.2. Many of the subsections use the 
DOE/ORP-2000-06

Rev. 0

diagram in Figure 1-2 to describe the management process in more detail. The major drivers, how the process is accomplished, and resulting products are then placed onto the diagram as appropriate. This provides a process and document hierarchy for each of the management processes. It should be emphasized that the ORP manages the contractors by way of their contracts. The documents and processes shown and discussed regarding the work management (contractor) layer are meant to be illustrative. Requirements on the contractors are as specified in their contracts.

The remainder of the PMP is organized into six sections:

- Section 2.0, Project Description, briefly discusses the background, mission, scope, and key planning assumptions of the RPP.

- Section 3.0, Organization and Responsibilities, portrays the organization, responsibilities, and organizational interfaces of the RPP.

- Section 4.0, Project Baseline, describes the integrated baseline, shows the work breakdown structure (WBS) and overall logic of the project, and summarizes the baseline cost and schedule.

- Section 5.0, Project Control, describes the management systems used to control the RPP, including systems engineering (SE), CM, baseline change control, contract management, performance measurement, information and reporting, interface management, work authorization, work management, risk management, construction project management, and communications and stakeholder/public involvement.

- Section 6.0, Compliance, describes how the Integrated Safety Management (ISM) System is set up to ensure environmental management, occupational safety and health, nuclear safety, and radiological safety. It also describes the management of quality assurance (QA), emergency management, and safeguards and security (SAS).

- Section 7.0, References, contains a reference listing of all documents called out in the PMP. 
DOE/ORP-2000-06

Rev. 0

\subsection{PROJECT DESCRIPTION}

\subsection{BACKGROUND}

Since 1944, highly radioactive waste from the chemical processing of irradiated reactor fuel has been stored in underground storage tanks at the Hanford Site. Approximately 204 million liters (54 million gallons) of caustic liquid, salt cake, and sludge wastes are currently stored in 177 tanks in 18 tank farms.

In 1986, regulators from the U.S. Environmental Protection Agency (EPA) and the Washington State Department of Ecology (Ecology) began to examine how best to bring the Hanford Site into compliance with the Resource Conservation and Recovery Act of 1976 (RCRA) and the Comprehensive Environmental Response, Compensation, and Liability Act of 1980. The regulators and the DOE agreed to develop one compliance agreement that established agreed-upon milestones for cleaning up hazardous substances. The three agencies concluded negotiations in late 1988, and signed the Hanford Federal Facility Agreement and Consent Order (known as the Tri-Party Agreement) on May 15, 1989. The Tri-Party Agreement is a primary driver of the RPP actions. During this time, the RPP was known as the TWRS.

In January 1994, the original Tri-Party Agreement milestones for TWRS were revised significantly because of rebaselining by the DOE. The DOE conducted this rebaselining through negotiations with the regulators and discussions with the public and stakeholders. In 1996, the agencies again changed the Tri-Party Agreement in response to a DOE initiative to use private industry to help remediate the tank waste. Currently, the agencies are negotiating changes to align waste retrieval and waste treatment milestones with the privatized Waste Treatment Plant contract.

In accordance with the National Environmental Policy Act of 1969, the DOE issued the "Record of Decision for the Tank Waste Remediation System, Hanford Site, Richland, WA" in 1997 (62 FR 8693). A phased approach to cleanup of the waste was chosen as the preferred alternative. Under this alternative, tank waste will be safely stored until retrieved for treatment and disposal. This will be done by implementing an initial phase (Phase 1) to verify that the treatment processes will function effectively, and then by implementing a full-scale production phase (Phase 2).

In 1998, as directed by Congress, the DOE established the ORP to manage all aspects of the RPP, including those portions under privatization contracts.

\subsection{RIVER PROTECTION PROJECT MISSION AND SCOPE}

"The mission of the RPP is to store, retrieve, treat, and dispose of the highly radioactive Hanford tank waste in an environmentally sound, safe, and cost-effective manner." (See DOE/ORP-2000-10, River Protection Project Mission Analysis Report.) The strategy to accomplish the mission is described in the RPP Strategic Plan and shown graphically in Figure 2-1. The RPP strategy integrates waste storage, waste retrieval, waste treatment, and 
DOE/ORP-2000-06

Rev. 0

immobilized waste storage and disposal. The high-level waste fraction will be vitrified and sealed in canisters that can be stored on the Hanford Site before final shipment to a geologic repository for disposal. The low-activity waste fraction will be immobilized and sealed in containers suitable for permanent, near-surface disposal on the Site.

Figure 2-1. River Protection Project Mission.
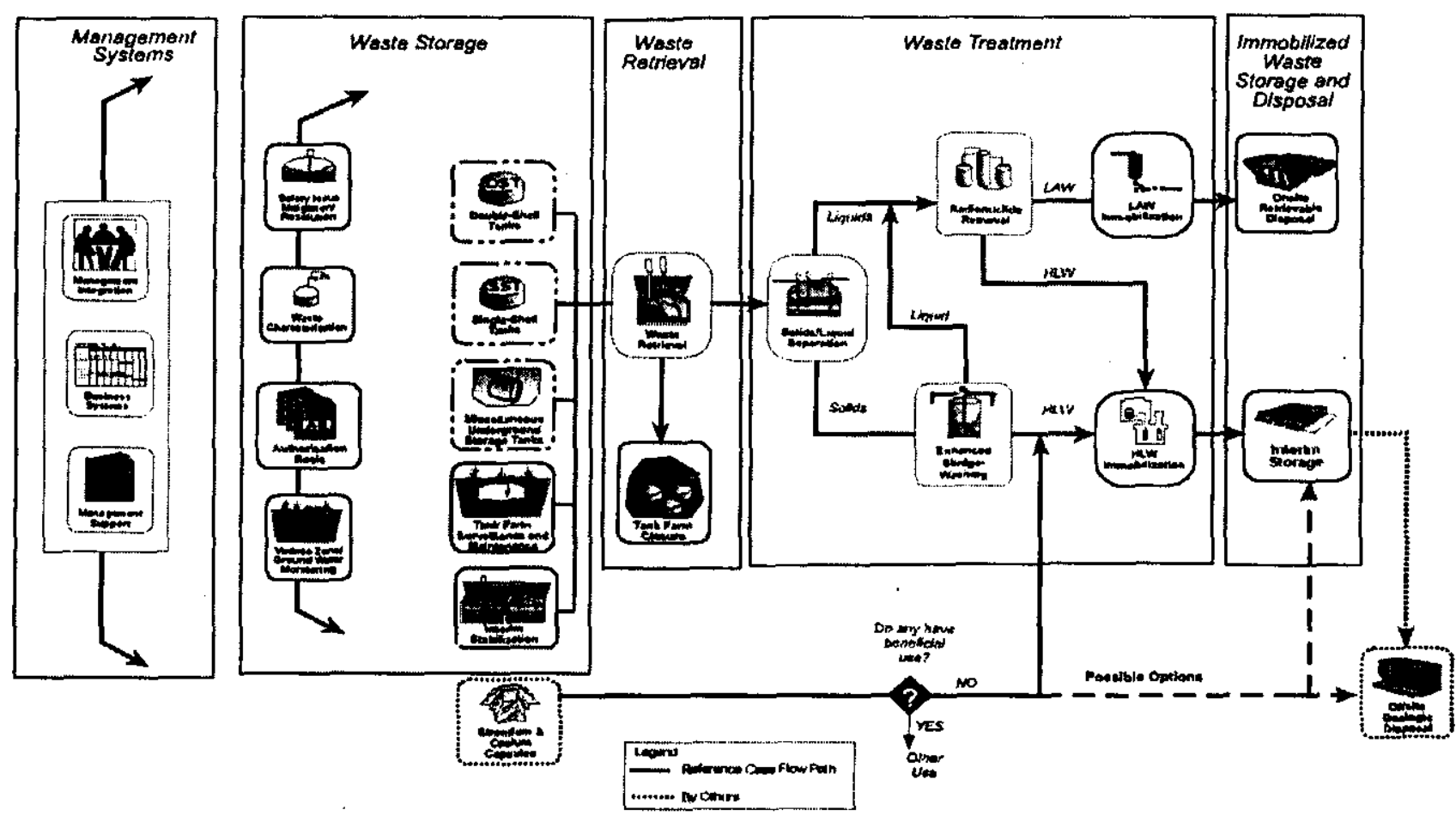

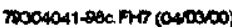

Specific elements of the RPP scope include the following:

- Provide resources and management systems necessary to manage, integrate, control, and support mission success.

- Safely store waste before and during retrieval.

- Resolve/mitigate safety issues.

- Provide an Authorization Basis for safe operation.

- Characterize waste.

- Monitor the vadose zone and groundwater.

- Safely store waste in single-shell, double-shell, and miscellaneous underground storage tanks. 
DOE/ORP-2000-06

Rev. 0

- Perform surveillance and maintenance of tanks and waste.

- Interim stabilize single-shell tanks to prevent leakage.

- Retrieve waste.

- Retrieve waste from all tanks in a safe and environmentally sound manner.

- Close the tank farms.

- Process waste.

- Separate solids from liquids.

- Provide enhanced sludge washing.

- Remove radionuclides.

- Immobilize low-activity waste.

- Immobilize high-level waste.

- Disposition strontium and cesium capsules.

- Store and dispose of immobilized waste.

- Dispose of immobilized low-activity waste onsite.

- Interim store high-level waste for eventual offsite geologic disposal.

- Decontaminate, decommission, and initiate post-closure monitoring of RPP facilities.

To accomplish this mission, the DOE developed a two-phased strategy involving procurement of waste treatment services (separations, sludge washing, radionuclide removal, and low-activity waste and high-level waste immobilization) with a privatized, fixed-price contract, and procurement of the remaining scope of services with a cost-plus-fee contract.

Phase 1 is divided into two parts: Part A and Part B. During Part A, two private contractor teams produced competing conceptual designs for waste treatment plants. After review, the DOE selected one contractor, BNFL Inc. (BNFL) to proceed to Part B. During the first portion of Part B (Part B-1), BNFL will complete additional design work for its Waste Treatment Plant, sufficient to establish firm fixed-unit prices and financial terms for providing waste treatment services. If the DOE authorizes BNFL to proceed to the second part of Part B (Part B-2), BNFL will complete the design, and construct and operate its Waste Treatment Plant to treat at least $10 \%$ of the tank waste mass and $25 \%$ of the included radioactivity by 2018 . 
The TFC provides the remaining scope of services for Phase 1 on a cost-plus-fee basis. This scope includes safe storage, retrieval, and storage and disposition of immobilized waste, and decontamination, decommissioning, and initiation of post-closure monitoring.

During Phase 2, the remaining tank waste will be processed. The RPP Mission Analysis Report provides details of the current planning.

\subsection{KEY PLANNING ASSUMPTIONS}

The ORP specifies key planning assumptions and associated issues for the RPP in RPP-5993, PIO Administration, Vol. II, Section 1, "River Protection Project Key Planning Assumptions." A summary follows:

\section{Phase 1}

- Budget/Financial - Funding will be constrained through 2001, and tied to full compliance requirements for 2002 and beyond.

- Permitting/Safety - Permits will be available and on time; the Authorization Basis will be amended to include double-shell tank waste retrieval activities, operations, and equipment; and ORP approval of the retrieval Authorization Basis amendment will authorize performing activities in flammable gas watch list tanks.

- Interfaces (Internal/External) - An integrated product and process development process will be used to manage all interfaces among ORP, the PC, and the TFC, and between the TFC and other onsite contractors. Key support facilities and personnel currently managed by non-ORP Hanford Site contractors (e.g., 242-A Evaporator) will be available to support the RPP mission.

- Waste Retrieval/Delivery/Receiving - The technical assumptions (e.g., tank waste inventory basis, feed delivery sequence and rates, key milestones, glass product parameters, chemical composition, and sampling) are defined and incorporated into interface documents and the project integrated schedule.

- Secondary Waste Treatment/Storage/Disposal - The PC liquid discharge and effluents will be within the permitted envelopes. Interface requirements will be managed with the integrated product and process development process.

- Immobilized Waste Storage/Disposal - Immobilized low-activity wáste will be disposed of onsite after performance assessments are completed, U.S. Nuclear Regulatory Commission criteria are confirmed, and DOE authorization is received. Immobilized high-level waste will be stored in the Canister Storage Building at the Hanford Site before transfer to a federal repository for final disposal. 
DOE/ORP-2000-06

Rev. 0

Phase 2

- Storage - Double-shell tanks will be used for feed accumulation and conditioning activities. Replacements will be constructed as necessary.

- Waste Feed Retrieval/Feed Delivery - All single-shell tanks will be retrieved to the $99 \%$ removal objective. Past-practice sluicing with appropriate barriers will be the assumed baseline. Alternative technologies will be developed, deployed, and evaluated.

Deployment of interim barriers to control vadose zone infiltration before retrieval will be considered.

- Waste Feed Treatment - Phase 2 treatment capacity is limited to two Phase 1 facilities. Proposed expansions are specified. Feed blending and oxide loadings will be optimized to minimize the number of immobilized high-level waste canisters transferred to the repository.

- Regulatory/Safety - Completion of the mission will comply with the Nuclear Waste Policy Act of 1982 and Washington State implementation of RCRA requirements. 
DOE/ORP-2000-06

Rev. 0

This page intentionally left blank. 
DOE/ORP-2000-06

Rev. 0

\subsection{ORGANIZATION AND RESPONSIBILITIES}

An integrated project management team has been established to carry out the RPP mission. The team consists of the ORP; U.S. Department of Energy, Richland Operations Office (RL) and DOE-HQ organizations; and supporting contractors. The PMP presents an overview of the RPP organization. The details of the ORP organizations and responsibilities are described in DOE/ORP M 411.1-1, Office of River Protection Functions, Responsibilities, and Authorities Manual (FRAM).

\subsection{RIVER PROTECTION PROJECT ORGANIZATION AND RESPONSIBILITIES}

The relationships between the ORP and other DOE organizations and contractors committed to accomplishing the ORP mission are shown in Figure 3-1. The ORP is located at the Hanford Site and reports directly to the Assistant Secretary, Environmental Management at DOE-HQ. The ORP is managed by a senior DOE official responsible for managing all aspects of the RPP, including the management of the $\mathrm{PC}$, which will design, build, and operate facilities for treating and immobilizing the waste, and the TFC, which is conducting the operations, maintenance, engineering, and construction activities in the 200 Area tank farms on the Hanford Site. The Manager, ORP coordinates with the Manager, RL who integrates ORP activities with other Hanford Site programs and provides administrative support to the ORP.

Figure 3-1. Organizational Relationships for Office of River Protection.

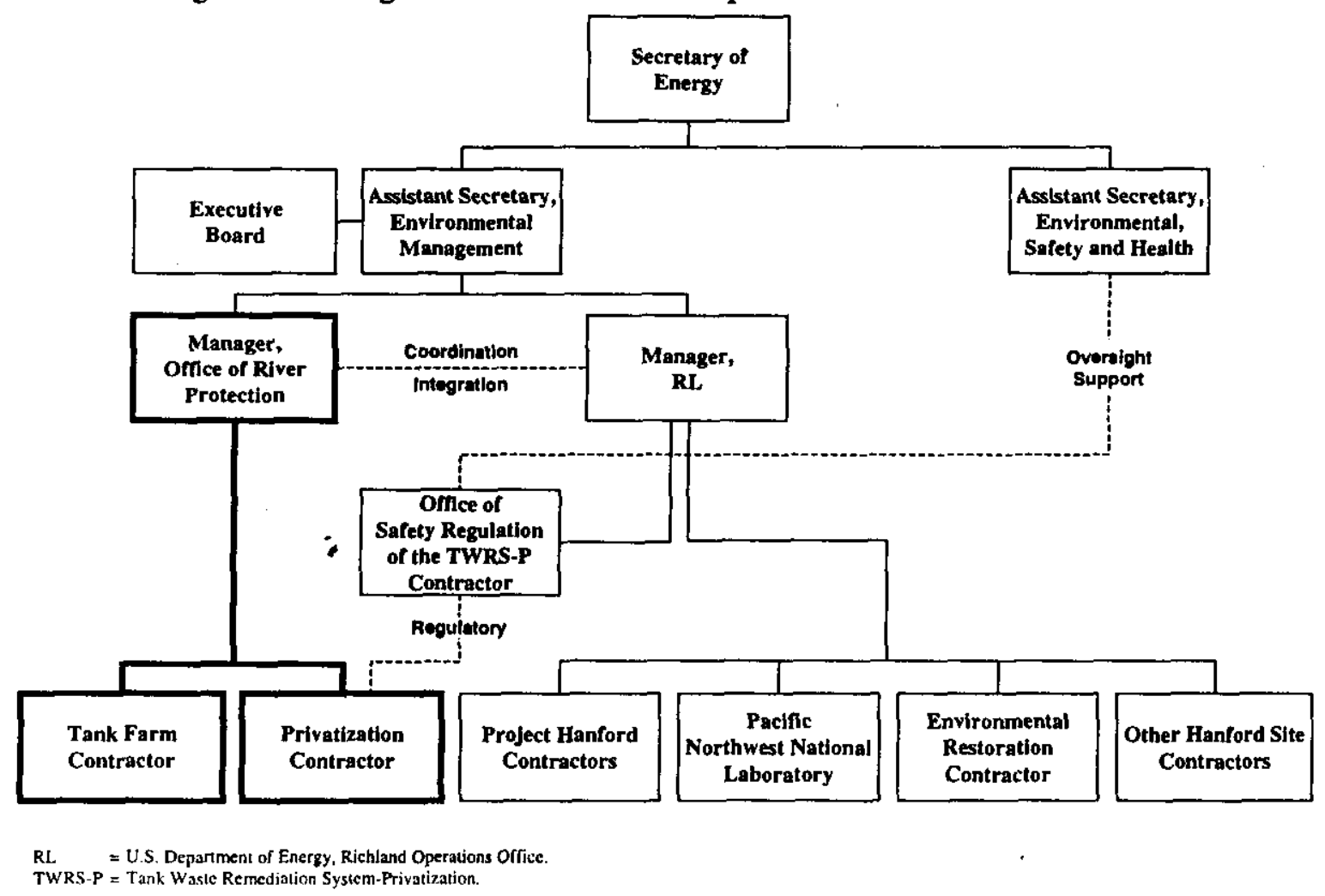


DOE/ORP-2000-06

Rev. 0

Three major organizations within the DOE (DOE-HQ, RL, and the ORP) have specific management roles and responsibilities for the RPP. The management tenets used to guide the assignment of roles and responsibilities include the following:

- RPP is a high priority within the U.S. Department of Energy, Office of Environmental Management (DOE-EM) Program.

- The Manager, ORP is responsible and accountable for successful execution of the RPP.

- The ORP reports programmatically to the Assistant Secretary, Environmental Management at DOE-HQ and coordinates Hanford Site activities with the Manager, RL.

These guiding tenets are embodied in the Memorandum of Agreement Among the Office of Environmental Management, the Richland Operations Office, and the Office of River Protection (MOA). The roles, responsibilities, and authorities for each organization are defined in the MOA and summarized as follows.

The Secretary of Energy is the Acquisition Executive for the RPP, which was designated a Strategic System in 1993. The Secretary uses the Energy Systems Acquisition Advisory Board to assist in approving all critical decisions.

The Assistant Secretary, Environmental Management has programmatic responsibility for the RPP and provides management oversight of the ORP. The Assistant Secretary chairs the ORP Executive Board and coordinates with Congress, other DOE-HQ offices, and other federal agencies. The Manager, ORP reports directly to the Assistant Secretary, providing a clear chain-of-command with accountability for management decisions.

The Assistant Secretary, Environmental, Safety and Health (ES\&H) provides technical support to regulate the PC and provides DOE-HQ oversight of ORP ES\&H functions.

The Office of Safety Regulation of the TWRS-Privatization Contractor is responsible for regulating nuclear, radiological, and process safety in privatized tank waste treatment and disposal facilities.

The Executive Board is chaired by the Assistant Secretary, Environmental Management. ORP Executive Board membership includes the ORP and RL Managers as well as senior DOE Managers from DOE-HQ organizations associated with the RPP. The ORP Executive Board works with the ORP to identify and help resolve critical issues related to the decision to proceed with construction and operation of the Waste Treatment Plant. The ORP Executive Board is kept informed of issues related to the entire project, including safe storage and retrieval functions, to support integrated decision-making. The ORP Executive Board reviews data, and reports to and assists the Assistant Secretary, Environmental Management with recommendations to the Secretary of Energy.

The Manager, ORP reports directly to the Assistant Secretary, Environmental Management, in coordination with the Manager, RL. The Manager, ORP is responsible for effectively managing all aspects of the ORP and RPP, including functions previously performed by the Assistant Manager of the TWRS organization. The Manager, ORP in partnership with the Manager, RL 
DOE/ORP-2000-06

Rev. 0

ensures effective integration between the ORP and other Hanford Site activities, coordinating activities to ensure mutual benefit to Sitewide operations for safe, effective operations and successful project execution.

The Manager, $R L$ in partnership with the Manager, ORP ensures effective integration between ORP and other Hanford Site activities. The Manager, RL is responsible for Hanford Site safety, security, and regulatory compliance and is a signatory on the Tri-Party Agreement and Sitewide permits and agreements. The Manager, RL provides administrative and technical support to the ORP, as requested by the Manager, ORP. Specifically, RL provides matrixed support for legal issues, landlord/support services, personnel, and real estate.

The DOE executes the work associated with the operation, maintenance, remediation, security, and environmental and energy research being conducted at the Hanford Site through contractors. All prime contracts needed to complete Phase 1 of the project are currently in place. The following paragraphs summarize the contractors and their roles on the project.

The TFC is responsible for tank waste storage, waste retrieval, interim storage of immobilized waste, and/or waste disposal. The Draft Project Execution Plan for the Tank Farm Contractor (RPP-6017) provides details of the TFC organization and management plan.

The PC is responsible for Phase 1 tank waste treatment. The contract scope includes designing, constructing, staffing, and operating the tank waste treatment facilities. The PC also is responsible for financing, acquiring permits and approvals for building and operating the facilities, and providing tank waste treatment services to the government at fixed-unit prices.

Details of the PC organizational structure, management plan, and procedures are provided in PL-W375-MG00001, River Protection Project - Waste Treatment Plant Project Management Plan. Under the privatization concept, the PC establishes and implements internal management procedures without significant involvement and direction by the DOE.

The Project Hanford contractors provide support to the ORP, the TFC, and the PC. The Project Hanford contractors are as specified in DOE contracts. Under the direction of the DOE, the Project Hanford contractors organize, plan, integrate, and manage most of the Hanford Site infrastructure and support services activities. Major support services that directly affect ORP mission objectives include the following:

- 242-A Evaporator operations for reducing waste volumes

- Liquid Effluent Retention Facility and Effluent Treatment Facility for managing liquid waste effluents

- 222-S Laboratory for characterizing tank waste

- Disposal of hazardous, low-level, radioactive, and mixed solid wastes.

Additional Hanford Site infrastructure and support services include engineering and construction management services, infrastructure services (e.g., providing computer systems, roads, electricity, and water), emergency management, and Site security. 
The Environmental Restoration Contractor conducts the Environmental Restoration Program at the Hanford Site. It plans, manages, and integrates activities associated with the vadose zone and groundwater beneath the tank farms. It also integrates vadose zone and groundwater activities conducted by the TFC, the Project Hanford contractors, and Pacific Northwest National Laboratory (Pacific Northwest).

Pacific Northwest supports the DOE's national security, environmental cleanup, and energy missions. Pacific Northwest provides technical and management services as part of the Waste Disposal Integration Team, including assistance in developing and managing the PC contract. Pacific Northwest also conducts research and technology development activities involving tank waste, vadose zone, and groundwater evaluations, and leads the Tank Focus Area, which is seeking solutions to tank waste technical problems at DOE sites across the nation.

Other Hanford Site contractors, including the Hanford Environmental Health Foundation and general support services contractors, support the ORP. The Hanford Environmental Health Foundation provides health risk management and occupational health services to maximize the health and safety of Hanford Site personnel.

Other federal and state agencies, not shown in Figure 3-1, provide regulation and oversight to the RPP. Federal and state agencies regulate the ORP in a manner similar to other activities on the Hanford Site. The external regulatory agencies and their specific roles include the following:

- EPA and Ecology regulate and administer all permits for treatment and storage operations under RCRA, the Washington State Hazardous Waste Management Act, and the Clean Air Act of 1955.

- The Washington State Department of Health regulates radioactive air emissions.

- EPA and Ecology regulate nonradioactive air emissions.

- EPA, Ecology, Washington State Department of Health, and/or local health agencies regulate liquid effluents. Most $P C$ liquid effluents will receive final treatment at other permitted Hanford Site facilities.

- Ecology and the U.S. Department of Transportation regulate offsite transport of radioactive waste and nonradioactive hazardous wastes.

\subsection{OFFICE OF RIVER PROTECTION ORGANIZATION AND RESPONSIBILITIES}

The Manager, ORP is supported by the ORP organization as depicted in Figure 3-2. 
DOE/ORP-2000-06

Rev. 0

Figure 3-2. Organization Chart for Office of River Protection.

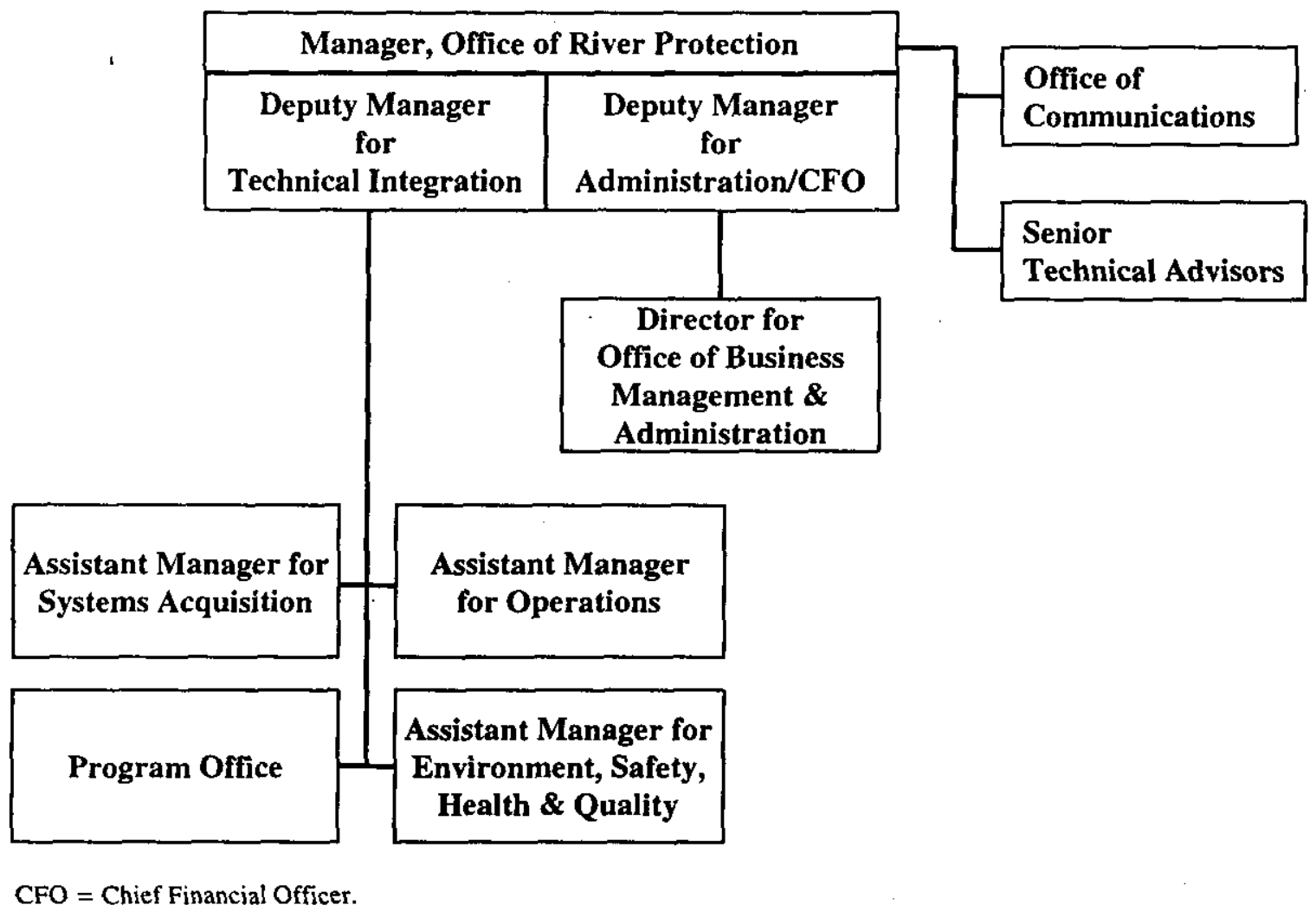

The roles, responsibilities, and authorities for each organization are summarized below (refer to the FRAM for details).

The Deputy Manager for Administration/Chief Financial Officer directs and manages finance and administration activities. The Deputy Manager provides management direction and guidance to the Director for Office of Business Management and Administration.

The Director for Office of Business Management and Administration develops and oversees crosscutting business and administrative functions, such as submitting and supporting the ORP budget, managing the budget and funds process, and maintaining the finance system. As the Contracting Officer for ORP's prime contracts, the Director performs procurement activities in accordance with federal regulations, administers the ORP contracts, oversees the contractors' financial and procurement systems, and acts as the focal point for coordination with RL Site infrastructure. The Director's Administration responsibilities include federal organization, staff training, and qualifications. 
The Deputy Manager for Technical Integration is responsible for developing and maintaining the integrated performance and technical baselines. In this role, the Deputy Manager provides management direction and safety oversight for the operations, systems acquisition, ES\&H, and Program Office functions. These functions are discharged through the following organizations:

- The Assistant Manager for Operations ensures the tank waste is safely stored and managed. In addition, the Assistant Manager for Operations ensures waste is maintained in a safe configuration until the processing facility is ready, ensures the waste is retrieved and pumped to the Waste Treatment Plant, and conducts immobilized waste retrieval and storage/disposal operations. The Assistant Manager for Operations has line management responsibility for operational safety, including ISM System implementation.

- The Assistant Manager for Systems Acquisition is responsible for safely delivering projects that retrieve, stage and transfer, treat, immobilize, store, and dispose of Hanford Site tank waste. In this role, the Assistant Manager for Systems Acquisition:

(1) provides direction to contractors responsible for the design, construction, and commissioning of projects; (2) defines project requirements; (3) evaluates contractor performance against project requirements; (4) manages and controls systems interfaces between individual projects and the contractors responsible for each project; and (5) optimizes projects to improve cost and schedule performance.

The Assistant Manager for Systems Acquisition has line management responsibility for the safety of operations and activities in the workscope described in this section except for the tank waste treatment-contracted facilities and activities of the PC. The safety responsibility for line management of the privatization contract resides with the RL Office of Safety Regulation of the TWRS-Privatization Contractor.

- The Program Office develops and manages the performance and technical baselines of the RPP and establishes strategic project and program planning that identifies and is responsive to performance metrics.

- The Assistant Manager for Environment, Safety, Health and Quality (ESH\&Q) ensures work is being performed safely, efficiently, and in compliance with applicable environmental permits and statues. The Assistant Manager for ESH\&Q also ensures that quality programs are in place and implemented, and manages the ORP Authorization Basis. In addition, the Assistant Manager for ESH\&Q ensures ORP is fully coordinating with the Regulatory Unit on ESH\&Q matters as they relate to the privatized Waste Treatment Plant. The Assistant Manager for ESH\&Q is also the point of contact for employee concerns and the Defense Nuclear Facilities Safety Board (DNFSB).

The Office of Communications provides support in the areas of government relations, public involvement, emergency response, regulatory affairs, and media relations. It interacts with Hanford Site personnel, DOE-HQ personnel, and stakeholders by providing press releases and conferences, media kits, tours/briefings, and issue papers. In addition, it prepares a monthly ORP Employee Newsletter and provides input to the Hanford Reach (the Hanford Site newspaper). 
Senior technical advisors provide advice on nuclear and radiological safety, strategic planning, technological and scientific issues, project management, and organizational effectiveness. The senior technical advisors may assist any part of the ORP organization, and report directly to the Manager, ORP.

\subsection{ORGANIZATIONAL INTERFACES}

Successful execution of the ORP mission requires clear communication of direction and feedback between the ORP and external regulators and stakeholders. The following paragraphs address the interfaces between the ORP and the DNFSB, federal and state regulatory entities, and DOE-EM and RL, and the interfaces between the RPP and other Hanford Site contractors.

\section{Interface Between the ORP and the DNFSB}

The interface between DOE organizations and the DNFSB is detailed in DOE M 140.1-1A, Interface with the Defense Nuclear Facilities Safety Board. In summary, the Secretary of Energy maintains an interface with the DNFSB through the Departmental Representative to the Board. The Departmental Representative advises the Secretary, Under Secretary, and the Secretarial Officers on DNFSB issues. An RL liaison develops requested interfaces between the ORP and the DNFSB.

\section{Interfaces Between ORP and Federal and State Environmental Regulatory Entities}

The DOE-EM policy for negotiating and approving environmental compliance and cleanup agreements is delineated in Review and Approval Guidance for Environmental Compliance and Cleanup Agreements for the Office of Environmental Management, signed by the Assistant Secretary, Environmental Management on June 6, 1997. The guidance states that the Field Office will take the lead in agreement negotiations and will establish a DOE negotiation team. A DOE-HQ negotiation support team consisting of the DOE-EM Program Office, Office of Environmental and Regulatory Analysis, and Office of the Assistant General Counsel for Environmental Representation is assigned to each agreement. The lead DOE-HQ Program Manager serves as the primary liaison between the Field Office and the other DOE-HQ negotiation support team members and ensures inclusion of other team members throughout the process.

The Assistant Secretary, Environmental Management approves all new agreements or significant modifications of existing agreements, with concurrence from appropriate DOE-HQ elements, unless other levels are agreed. The lead DOE-EM Program Manager consults with the other DOE-HQ support team members to develop a joint recommendation regarding the significance of a modification to an existing agreement. RL provides the primary RPP liaison with Ecology.

\section{Interface Among ORP, RL, and DOE-EM}

The MOA among the ORP, RL, and DOE-EM documents ORP organizational authorities, roles, and responsibilities and establishes a reporting structure. The primary interface role of RL with the ORP is to ensure effective integration between the ORP and other Hanford Site activities (including budget preparations). RL also provides activities, such as administrative and technical 
support, to the ORP upon request; maintains responsibility for Hanford Site safety, security, and regulatory compliance; and acts as the signatory authority for certain Sitewide permits and agreements.

To ensure communication between ORP management and the RL Office of Radiological, Nuclear and Process Safety, the Manager, ORP meets with the Manager, RL once per month, and the Assistant Manager for Systems Acquisition meets with the RL Office of Radiological, Nuclear and Process Safety Regulatory official. Additionally, a Liaison Officer resides with the Office of ESH\&Q to maintain frequent contact with the RL Office of Radiological, Nuclear and Process Safety.

\section{Interfaces Between RPP and other Hanford Site Contractors}

The TFC provides and receives services from other Hanford Site contractors through the use of MOAs. The RPP is encouraged to use the expertise of the Project Hanford contractors, Pacific Northwest, and the Environmental Restoration Contractor to accomplish its mission. 
DOE/ORP-2000-06

Rev. 0

\subsection{PROJECT BASELINE}

\subsection{INTEGRATED BASELINE DEFINITION}

An integrated cost, schedule, and technical baseline is established and maintained throughout the RPP life cycle (see Figure 4-1). The integrated baseline is used to perform the following:

- Manage the RPP as a single project with activities performed by several participants (ORP, the TFC, the PC, and support contractors).

- Provide the foundation for integrated planning, budgeting, and logic-driven, critical path scheduling of the entire RPP workscope.

- Establish approved project cost, schedule, and technical objectives.

- Aid in establishing interface agreements among project participants.

- Support development of meaningful performance measures and contract incentives.

- Monitor progress during project execution.

- Define the project and its components for approval and work authorization.

- Ensure accurate information on the configuration of the physical system.

- Identify key decision points.

The technical baseline represents the configuration as developed and described in Section 4.2. The programmatic baseline, which consists of the scope, cost, and schedule baseline, is derived from the workscopes described in the WBS and its associated dictionary (see Section 4.4). The cost baseline is the approved, projected, time-phased, life-cycle costs for acquiring, operating, and disposing of the physical system represented by the technical baseline. The schedule baseline is the approved timeline for acquiring, operating, and disposing of the physical system. The baseline is integrated where the time-phased cost baseline is consistent with the schedule baseline, and the costs are related to acquiring, operating, and disposing of the physical system represented by the technical baseline.

The RPP integrated baseline schedule is constructed and maintained using a schedule : specification mutually agreed to by the ORP, the PC, and the TFC (see RPP-5993, PIO Administration, Vol. VI, Section II, "PIO Master Schedule Integration Specification"). 
Figure 4-1. Integrated Baseline Development Document Hierarchy and Process.

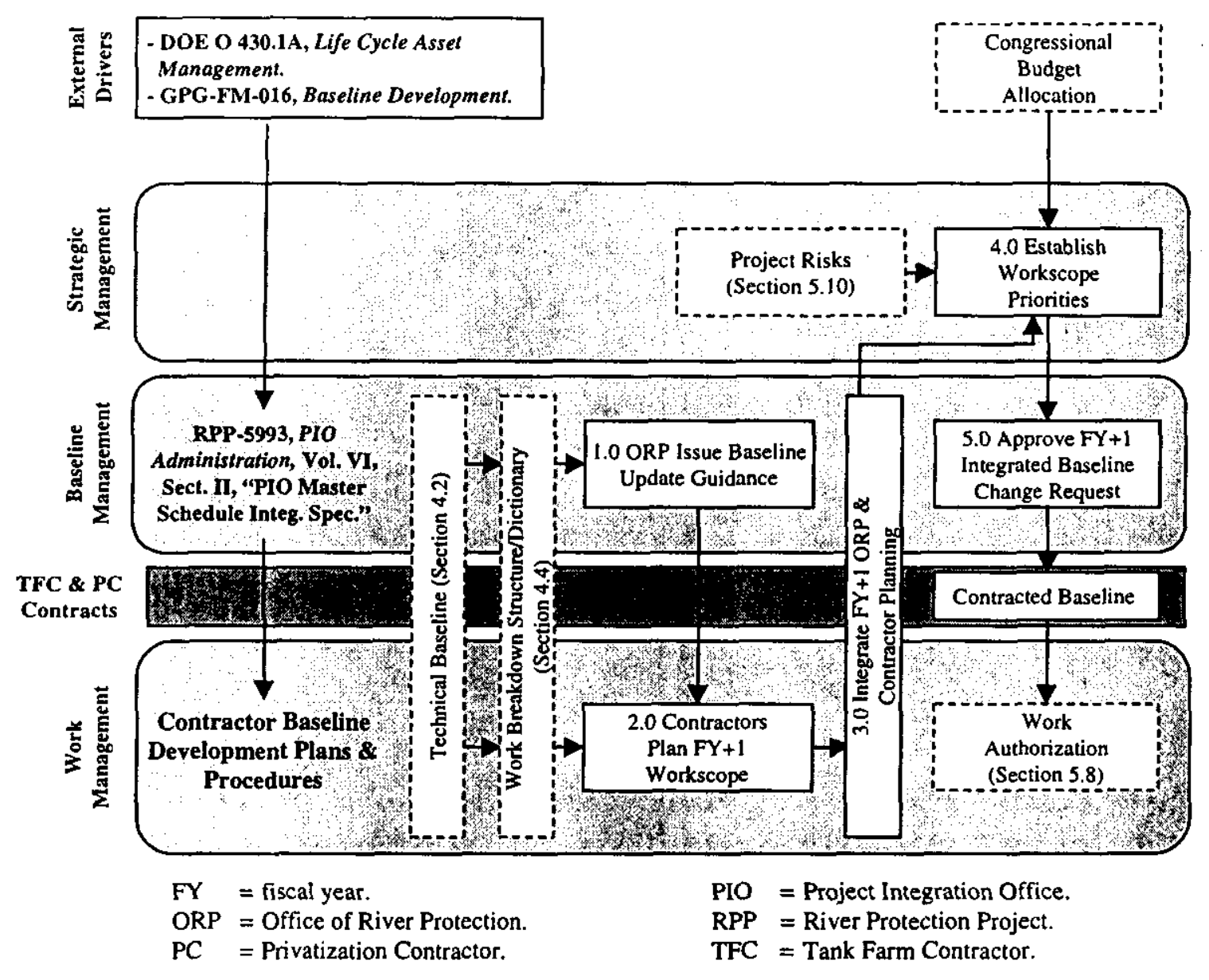

General Process - The general process is shown in Figure 4-1. The RPP integrated baseline currently exists, and covers the life of the RPP. This life-cycle baseline can be changed as often as necessary, but typically is updated annually, based on the Congressional budget cycle. Planning by ORP is done only to the extent that assumptions/guidance have changed from the previous year.

1.0 ORP Issue Baseline Update Guidance. Two years before the date that work is to be executed, ORP submits its proposed (fiscal year $[\mathrm{FY}]+2$ ), budget to DOE-HQ. One year later, upon DOE-HQ submittal of its FY+1 budget to the Office of Management and Budget, the ORP issues FY+1 baseline update guidance to its contractors. This guidance is based on an anticipated appropriation by Congress. It includes updated technical requirements (technical specification) and key assumptions as a basis for $F Y+1$ baseline update planning. As a part of this process, the ORP, the PC, and the TFC mutually agree on key assumptions for the RPP work. 
2.0 Contractors Plan FY+1 Workscope. Using the baseline update guidance and key assumptions, the Prime Contractors decompose the FY+1 workscope into work activities, organize the activities into a logical sequence for performing the work, and estimate activity durations and resources required to perform the activities. The product is a logic-driven, critical path, resource-loaded schedule. The amount of work performed for this step depends mainly on the amount of changes in the planning assumptions from the previous year.

3.0 Integrate FY+1 ORP and Contractor Planning. The ORP and contractors identify. activity interface points and relationships among the contractor activities. The schedules are merged, resource loaded and leveled, and iterated to resolve schedule and cost impacts.

Section 4.6 provides the RPP management summary schedule.

4.0 Establish Workscope Priorities. Upon Congressional appropriation of funds and DOE-HQ allocation of the funds to the RPP, the FY+1 workscope is prioritized to enable authorization of the FY+1 work that should be performed with available funds. The ORP determines prioritization criteria based on schedule and risk conditions. The product of this activity is a Project Priority List.

5.0 Approve $F Y+1$ Integrated Baseline Change Request $(B C R)$. The ORP, through the baseline change control process (see Section 5.3), reviews and approves the realigned integrated baseline for work authorization. Changes to the ORP direct contracts authorize the execution of the integrated baseline at the contractor level.

\subsection{TECHNICAL BASELINE}

The technical baseline is defined as the set of equipment, facilities, materials, staff qualifications, and enabling documentation needed to start up and complete mission objectives. The RPP technical baseline consists of the following parts: requirements baseline, design baseline, and operations baseline. It contains the physical system configuration in terms of functional, physical, operational, and performance requirements and their implementing architectures. The requirements portion of the technical baseline is generated and verified using SE processes (see Section 5.1), and controlled using CM and change control processes (see Sections 5.2 and 5.3). The design and operations portions of the technical baseline are generated and controlled using. traditional engineering and operations methods.

The technical baseline represents, and includes, the physical system that will achieve the technical goals and objectives for the RPP as established in the RPP Strategic Plan and RPP Mission Analysis Report. Figure 4-2 shows this technical baseline hierarchy. Note that the technical baseline hierarchy starts with the requirements baseline and progresses down in more detail, becoming the design baseline (engineering drawings). The figure does not show the operations baseline, which consists of equipment, operating, and maintenance procedures; system descriptions; etc. 
DOE/ORP-2000-06

Rev. 0

Figure 4-2. Technical Baseline Document Hierarchy and Process.

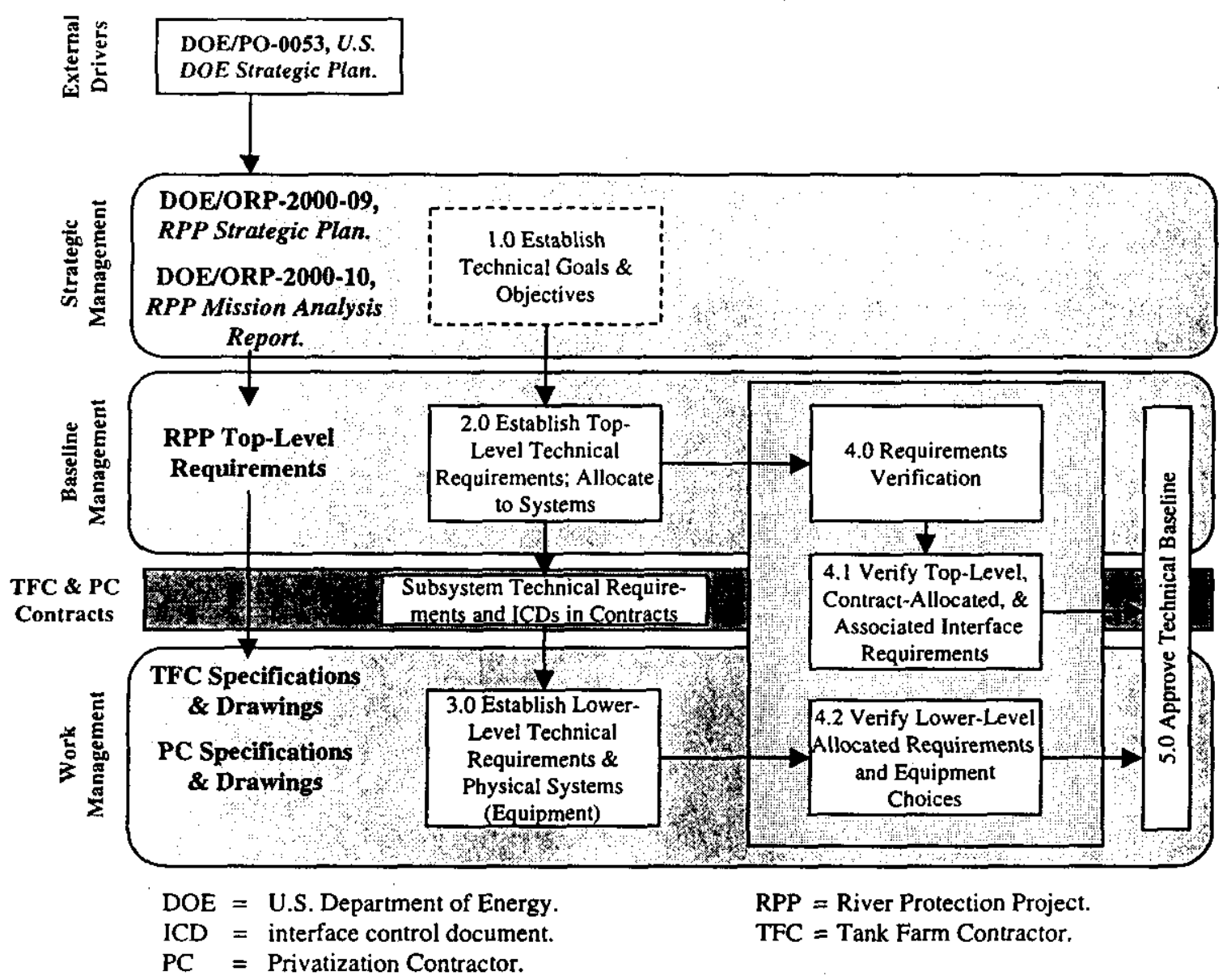

General Process - The structure and general process for developing the technical baseline are shown in Figure 4-2 and described as follows:

1.0 Establish Technical Goals and Objectives. The RPP Strategic Plan and RPP Mission Analysis Report include a description of the technical goals and objectives. The goals and objectives contained in these documents provide the departure point for developing the top-level technical requirements contained in the requirements portion of the RPP technical baseline.

\subsection{Establish Top-Level Technical Requirements; Allocate to Systems. SE processes} (functional and requirements analyses, etc.) develop the top-level functional, operational, and performance requirements (including regulatory requirements) that must be met to achieve the technical goals and objectives contained in the RPP Strategic Plan and RPP Mission Analysis Report. These top-level requirements are allocated to systems (major facilities) that are assigned to contractors, and invoked in their respective contracts, for further development and architectural implementation. Interface control documents (ICD) define the interfaces among the contracted subsystems to ensure the delineation and assignment of interfaces are clearly 
understood. External interfaces also exist between the RPP and its waste generators and receivers (e.g., federal waste repository). ICDs are part of the technical baseline.

The existing Tank Farm System will be able to perform parts of the Tank Waste Storage and Retrieval elements of the RPP scope. The existing system and associated requirements are documented as part of the technical baseline. Furthermore, the inventory of waste within the scope of the RPP is documented and maintained as the inventory changes.

\subsection{Establish Lower-Level Technical Requirements and Physical Systems (Equipment).}

The contractors further decompose and allocate requirements to lower-level subsystems and components, and design the equipment to implement those requirements. The design portion of the technical baseline includes items such as specifications and drawings. The various specifications include system specifications, subsystem specifications, component specifications, procurement specifications, and construction specifications. The equipment and any other documentation that describes the equipment, facilities, processes, materials, and staff qualifications necessary to perform the RPP mission are the operations portion of the technical baseline.

4.0 Requirements Verification. Requirements are verified to ensure correctness and internal consistency, and to ensure the equipment meets requirements, before becoming part of the technical baseline. Verification is performed by analyses, tests, demonstration, inspection, and operational performance.

4.1 Verify Top-Level, Contract-Allocated, and Associated Interface Requirements. The scope of verification for the ORP pertains to the overall top-level requirements, the contract-invoked subsystem technical requirements, and the external and contract-level interface requirements.

4.2 Verify Lower-Level Allocated Requirements and Equipment Choices. The contractors verify the lower-level requirements and equipment choices. Verification includes traceability of top-level requirements to their lower-level implementing requirements and equipment.

5.0 Approve Technical Baseline. Upon verification, the requirements and equipment are formally approved as part of the technical baseline. As the design and operations baselines are verified, they also are formally approved as a part of the technical baseline.

\subsection{DOCUMENT HIERARCHY}

Figure 4-3 shows the summary document hierarchy for the RPP. The document hierarchy is organized around the same management levels described in Section 1.2. The purpose of the document hierarchy is to show the hierarchical relationships among documents and the major categories into which the documents can be classified for management purposes. Hierarchical 
relationships provide a mechanism for traceability of requirements and summarization of detail cost, schedule, and technical entities for varying levels of management control.

Figure 4-3. Office of River Protection Document Hierarchy.

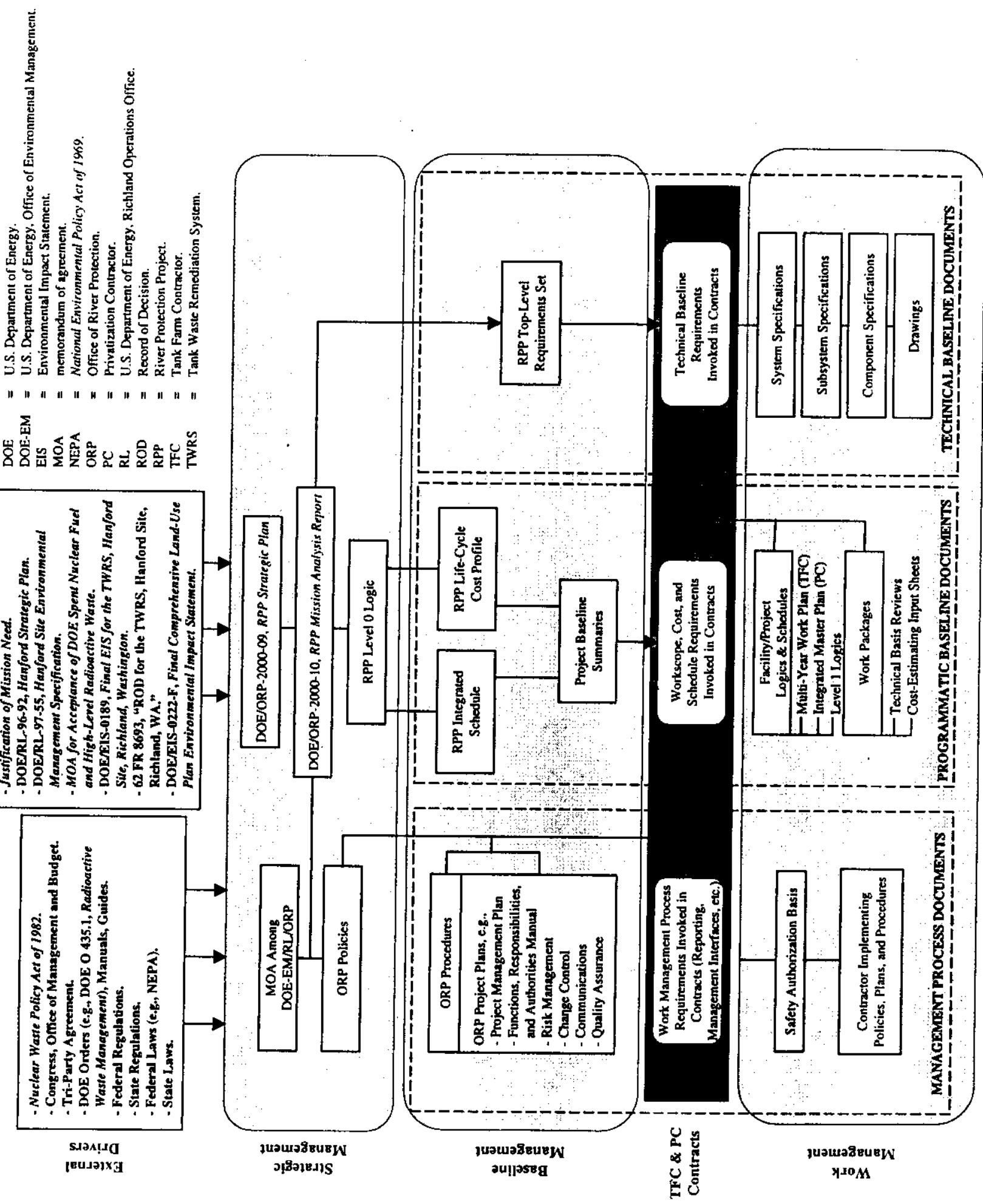


Rev. 0

External drivers. These documents include the legal, regulatory, management, and technical requirements from sources outside of the RPP that are implemented in the RPP management systems and applicable management and technical documents. Note that the drivers listed are primary examples, but there are numerous others, especially regulatory.

Strategic management. These documents contain the interpretation of the external drivers in the form of ORP management policies and the RPP strategy and mission documents. They provide top-level management and technical requirements and guidance that will be implemented through the lower-level documents.

Baseline management. These documents establish the ORP integrated management processes and the integrated baseline the ORP uses to manage the RPP. This level also contains the toplevel RPP requirements, which are kept in a database system.

Contracts. This level indicates a significant work authorization level where the work planned and described at the baseline level is performed under contract to the ORP. The contracts, including directives from the Contracting Officers, are the management control mechanisms that the ORP uses to pass to the contractors the description of, and the requirements and specifications for, the work.

Work management. These documents describe and control the work processes at the contractor level and expand the baseline cost, schedule, and technical requirements to the lowest control level. This layer also includes the Safety Authorization Bases for the contractors.

The document hierarchy is further organized by categories of documents: management process, programmatic baseline, and technical baseline.

Management process documents. These documents contain the policies and processes the ORP and its contractors use to manage the RPP. The execution of the policies and processes results in the programmatic and technical baselines and the products reflected in these baselines. Several examples of plans are provided at the baseline management level.

Programmatic baseline documents. These documents contain the workscope, cost estimates, and schedules for performing that work. The documents also provide a mechanism for authorizing the performance of the described work at the lowest level.

Technical baseline documents. These documents contain the requirements and description of the physical configuration of the facilities, process systems, and components that are required to accomplish the objectives of the RPP.

\subsection{WORK BREAKDOWN STRUCTURE}

The RPP WBS provides a common framework for work planning, scope, definition, and integration of the baseline for all levels and components of the project. The RPP WBS consists of ten major elements as shown in Figure 4-4. The ORP further defines these elements and provides them to the TFC and the PC for further decomposition. 
DOE/ORP-2000-06

Rev. 0

Figure 4-4. River Protection Project Work Breakdown Structure.

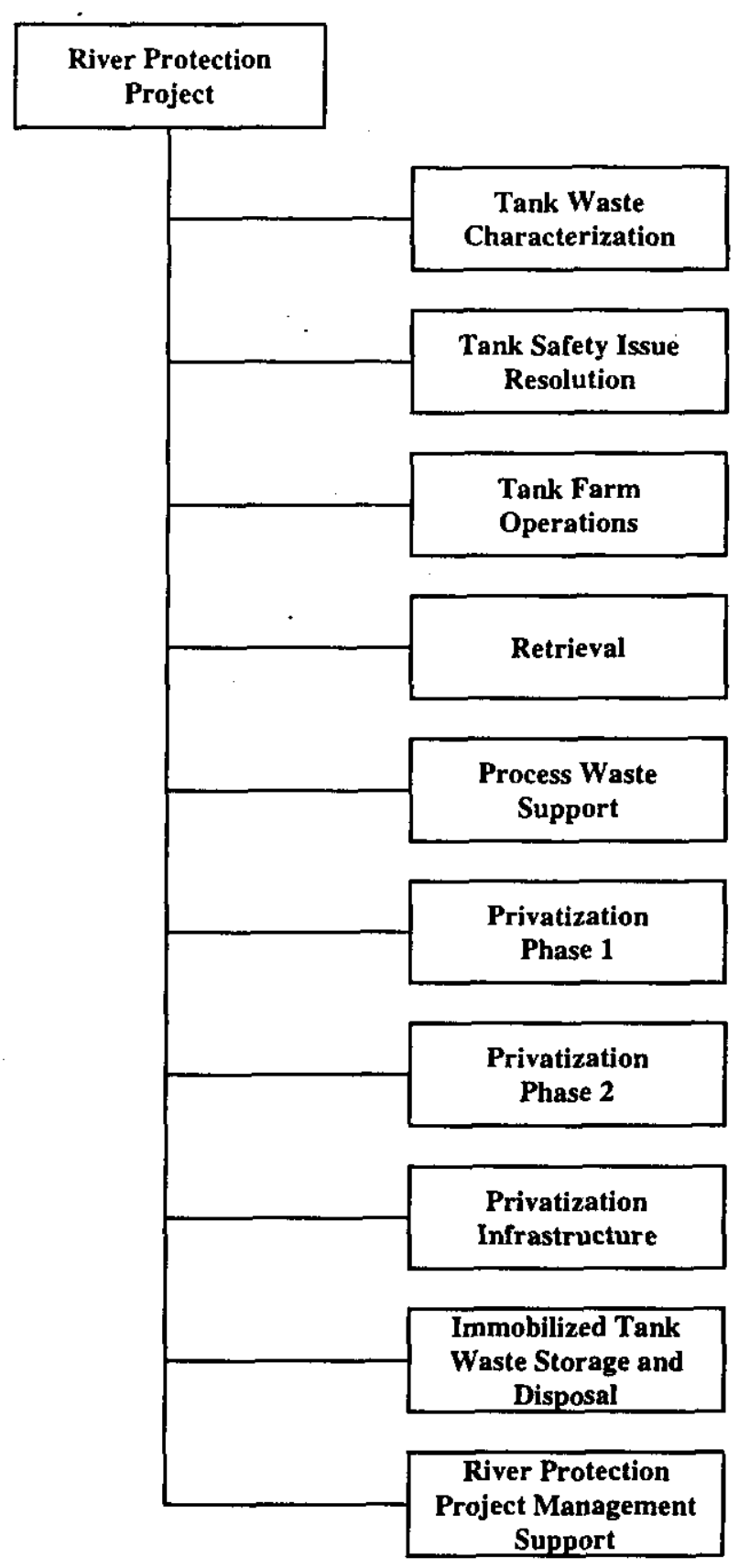


DOE/ORP-2000-06

Rev. 0

The PC is responsible for the WBS element "Privatization Phase 1" involving the Waste Treatment Plant. The PC has further decomposed this element into the following lower-level elements (see PL-W375-MG00001, River Protection Project - Waste Treatment Plant Project Management Plan):

- Management

- High-level waste

- Low-activity waste

- Pretreatment.

The WBS element "Privatization Phase 2" will hold all work descriptions for the Phase 2 portion of RPP. This WBS element will be developed by the contractor(s) chosen to implement that phase of the work.

The remainder of the WBS elements represent work that is being conducted by the TFC. The TFC has further defined its work into multiple lower-level elements (see RPP-5044, River Protection Project FY 2000 Multi-Year Work Plan [called the TFC MYWP in this PMP]).

The approved WBS and associated WBS data dictionary are part of the integrated RPP baseline and are subject to baseline change control as defined in Section 5.3.

\subsection{RIVER PROTECTION PROJECT LOGIC}

RPP Level-0 Logic Diagram TWR-2086 (see Figure 4-5) is a tool for translating the RPP mission requirements identified in the RPP Mission Analysis Report into a sequence of activities necessary to achieve the mission objectives. Figure 4-5 illustrates the major work that the RPP must perform to accomplish its mission, including safe storage, waste immobilization (Phase 1), waste immobilization and disposal completion (Phase 2), and closure. A diagonal line through the task box indicates tasks that have been completed. The logic also illustrates how PC activities integrate with the other contractor activities by way of the interface control shown in the linkages to the PC in Phase 1. Included in the logic are reevaluation points for Phase 1 and Phase 2 as committed to in 62 FR 8693, "Record of Decision for the Tank Waste Remediation System, Hanford Site, Richland WA."

Further decomposition of the RPP Level 0 logic activities generates a set of detailed activities that form the basis for all schedule and cost planning for the RPP. This process is further described in Section 4.1. 
DOE/ORP-2000-06

Rev. 0

This page intentionally left blank. 


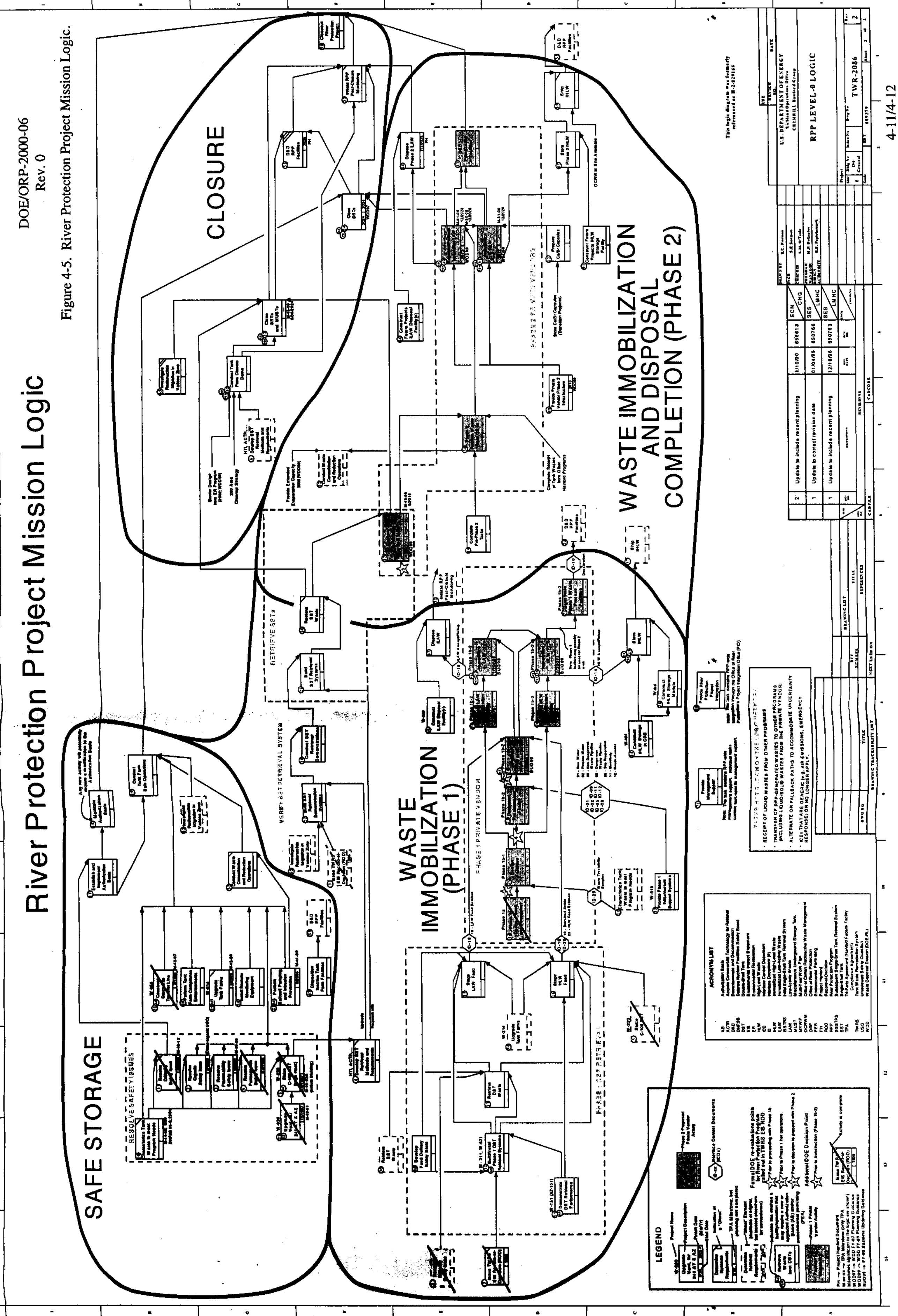


DOE/ORP-2000-06

Rev. 0

\subsection{BASELINE SCHEDULE AND COST SUMMARY}

The integrated schedule and cost for the RPP are summarized in Figure 4-6. This figure shows the scope, schedule, and cost necessary to perform the RPP mission. It is a product of the process described in Section 4.1. The management summary schedule defines the following eight major elements of the RPP integrated baseline scope:

- Safe Storage

- Phase 1 Infrastructure

- Phase 1 PC Facilities

- Phase 1 Waste Retrieval

- Immobilized Waste Storage and Disposal

- Phase 2 Waste Retrieval/Pretreatment/Vitrification

- Tank Farm Vadose Zone/Tank Closure

- Management Support.

The management summary schedule also identifies Waste Management and Laboratory Support as Project Hanford Management Contract (PHMC) (DE-AC06-96RL13200) scope required to support the RPP mission.

The RPP integrated schedule baseline is defined on the management summary schedule by external constraints and the associated dates, milestones, and identification of the RPP critical path. The RPP integrated cost baseline is defined on the management summary schedule by major element by year with annual totals (with and without PHMC costs) identified. Table 4-1 further summarizes these costs. The costs are broken out by tasks shown in Figure 4-6, and are totaled by previous years (FY 1996 to FY 1999), from FY 2000 to FY 2028 (completion of retrieval and waste treatment), and from FY 2029 to the year in which they occur. Note that all projected costs are escalated to the year in which they occur.

The management summary schedule is a summary representation of an automated, logic-driven, critical path, resource-loaded, life-cycle RPP integrated baseline schedule. The Program Office maintains the RPP integrated baseline schedule, which defines the project scope, schedule, and cost baseline at a detailed level. The RPP integrated baseline schedule was constructed and is maintained using a schedule specification mutually agreed to, and planning information provided by, the ORP, the PC, and the TFC. Changes occur based on authorized funding levels, completion strategies, technology, development, and refinements in estimates. 
DOE/ORP-2000-06

Rev. 0

Table 4-1. Cost Summaries (dollars in millions).

\begin{tabular}{|l|r|r|r|r|}
\hline \multicolumn{1}{|c|}{ Tasks } & $\begin{array}{r}\text { FY 1996 - } \\
\text { FY 1999 costs }\end{array}$ & $\begin{array}{c}\text { Projected } \\
\text { FY00 - FY28 } \\
\text { costs }\end{array}$ & $\begin{array}{c}\text { Projected } \\
\text { FY29 - FY48 } \\
\text { costs }\end{array}$ & $\begin{array}{c}\text { Projected } \\
\text { total project } \\
\text { costs }\end{array}$ \\
\hline Safe Storage & 613 & 4,228 & 850 & 5,691 \\
\hline Phase 1 Infrastructure & 18 & 378 & 0 & 396 \\
\hline Phase 1 Privatization Contractor Facilities & 385 & 10,096 & 0 & 10,481 \\
\hline Phase 1 Waste Retrieval & 223 & 3,062 & 0 & 3,285 \\
\hline Immobilized Waste Storage and Disposal & 21 & 4,667 & 465 & 5,163 \\
\hline $\begin{array}{l}\text { Phase 2 Waste Retrieval/Pretreatment/ } \\
\text { Vitrification }\end{array}$ & 0 & 26,721 & 36 & 26,757 \\
\hline Tank Farm Vadose Zone/Tank Closure & 0 & 384 & 301 & 685 \\
\hline Management Support & 107 & 1,140 & 275 & 1,522 \\
\hline \multicolumn{1}{|c|}{ Total RPP } & 1,367 & 50,686 & 1,927 & 53,980 \\
\hline $\begin{array}{l}\text { Waste Management And Laboratory Support } \\
\text { - Project Hanford Management Contract }\end{array}$ & 39 & 3,454 & 1,089 & 4,582 \\
\hline \multicolumn{1}{|c|}{ Overall total } & 1,406 & 54,140 & 3,016 & $58,562 *$ \\
\hline
\end{tabular}

NOTE: Projected costs are in Budget Authority dollars, and are escalated to the year in which the cost occurs.

*Unescalated total is $\$ 48,739$ in 2000 dollars.

FY = fiscal year.

RPP $=$ River Protection Project. 


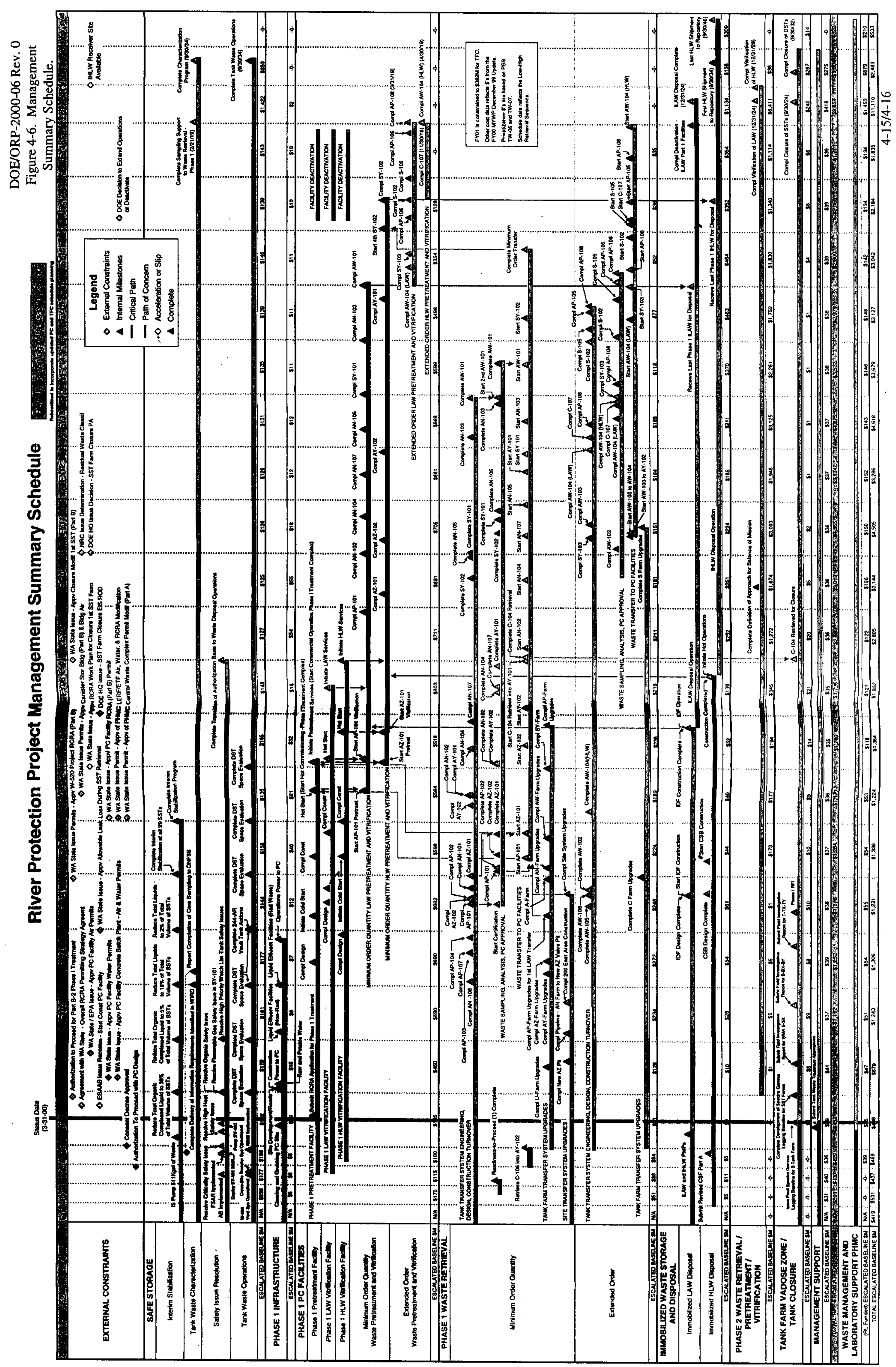


DOE/ORP-2000-06

Rev. 0

\subsection{PROJECT CONTROL}

This section describes the primary management processes that the ORP uses to maintain control of the RPP during each phase of its life cycle. These processes are integrated with each other such that management information flows seamlessly across the process boundaries. The processes are defined and implemented through the policies, procedures, and manuals that are referenced in their respective descriptions and associated diagrams. The management processes contained in this section are as follows:

- Systems Engineering Management

- Configuration Management

- Baseline Change Control

- Contract Management

- Performance Measurement

- Information and Reporting

- Interface Management

- Work Authorization

- Work Management

- Risk Management

- Construction Project Management

- Communications and Stakeholder/Public Involvement.

Each section contains a general process flow diagram containing a reference to the applicable requirements documents and blocks showing the major process functions. In some cases, a function is enclosed in a dashed block that indicates an interfacing function that is described in another section.

\subsection{SYSTEMS ENGINEERING MANAGEMENT}

The RPP uses SE principles across the entire life cycle of the project (i.e., design, construction, test, operation, and decontamination and decommissioning). The contract requires all RPP contractors to define and apply SE methods that are consistent with commercial processes for engineering a system (e.g., ANSI/EIA-632, Processes for Engineering a System) to define and control the technical basis for their work. A graded approach guides their application of SE. As shown in Figure 5-1, the external demand for an SE approach comes from DOE O 430.1A, Life Cycle Asset Management, as described in Good Practice Guide GPG-FM-010, Project Execution and Engineering Management Planning. Requirements in this Order are interpreted and pasised on to the RPP contractors via the RPP Strategic Plan and DOE/ORP-2000-12, Office of River Protection Life-Cycle Asset Management Policy.

Planning and execution for SE in the TFC, as required by contract, are through HNF-SD-WM-SEMP-002, Systems Engineering Management Plan for the Tank Farm Contractor (SEMP). The requirements in the SEMP are implemented through application of SE procedures in HNF-IP-0842, RPP Administration. Planning and execution for SE in the PC are through PL-W375-PP00001, Project Engineering Execution Plan. 
Figure 5-1 shows the major SE products. For the purposes of the PMP, SE has the primary function of defining the RPP physical system through preconceptual and conceptual definition, preliminary design, detailed design, and evaluation. Other functions classically within SE, such as risk management, $\mathrm{CM}$, and interface management, are described in separate sections.

Externally, the technical requirements for the RPP are defined in DOE/RL-97-55, Hanford Site Environmental Management Specification. The RPP Mission Analysis Report, congruent with the Site Specification, further defines the RPP. The top-level requirements are defined at the ORP level. At the contractor level, system specifications, subsystem specifications, component specifications, drawings, procurement specifications, and construction specifications complete the specification hierarchy.

Figure 5-1. Systems Engineering Documents, Process, and Products.

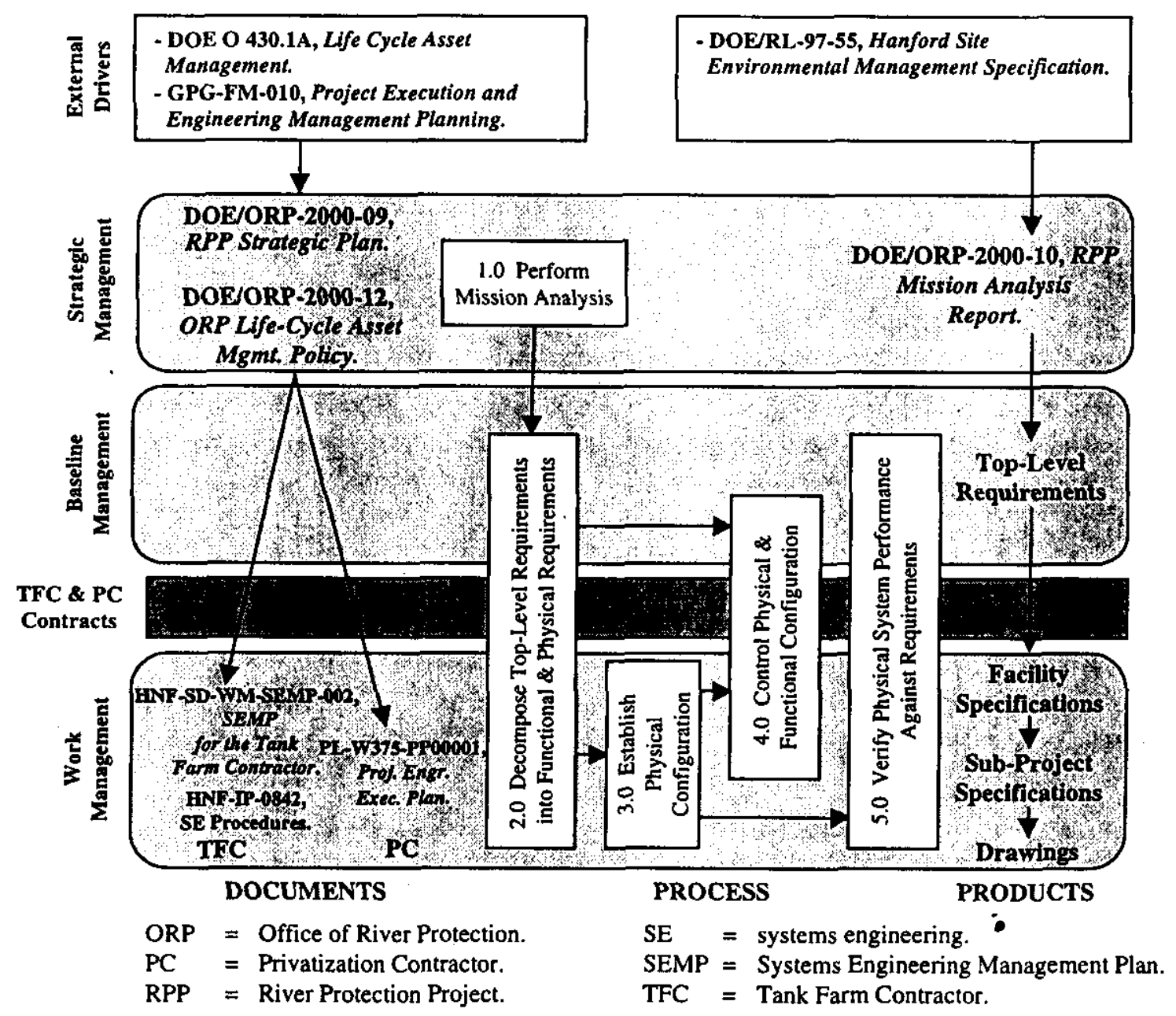

General Process - The following process is a general implementation of the SE process used to develop the technical baseline (see similarities with Section 4.2).

1.0 Perform Mission Analysis. An RPP mission analysis is performed and maintained to transform the strategic goals delineated in the RPP Strategic Plan into a set of 
top-level technical requirement which, when fully implemented in a physical system, will accomplish the strategic goals and objectives (see Section 4.2).

2.0 Decompose Top-Level Technical Requirements into Functional and Physical Requirements. The top-level technical requirements are decomposed and allocated into sets of functional and physical requirements for the physical system. Performance, reliability, maintainability, human factors, supportability, and other engineering specialties are integrated into the requirements development effort. Refer to Section 4.2 for the technical products that contain the requirements, form, fit, and function of the physical configuration.

3.0 Establish Physical Configuration. The SE process of top-down iterative functional analysis, synthesis, requirements development and allocation, optimization, and design of physical configuration that will satisfy the requirements is applied (see Section 4.2).

4.0 Control Physical and Functional Configuration. The configuration of requirements, form, fit, function, and technical interfaces among subsystems and components is controlled to ensure the overall system operates in a single, coordinated manner (see Section 5.2). The presence of an SE capability on Baseline Change Control Boards (CCB) is established to properly evaluate the technical impact of changes (see Sections 5.2 and 5.3).

5.0 Verify Physical System Performance Against Requirements. System performance is verified against requirements through analysis or test and evaluation (see Section 4.2).

\subsection{CONFIGURATION MANAGEMENT}

$\mathrm{CM}$ is the system for establishing and maintaining consistency of a product's performance, functional, and physical attributes with its corresponding requirements, design, and operational information throughout its life. The configuration of the RPP structures, systems, components, products, and processes must be managed throughout the life cycle of the project. CM is required to ensure the physical systems are properly identified and linked to their respective requirements, and the evolving design and operational form, fit, and function of the systems and facilities, as well as the acquired and installed configuration items, are known and controlled on a rigorous, real-time basis. The $\mathrm{CM}$ discipline is integrated with the SE and baseline change control functions to ensure the integrity of the technical baseline and changes to that baseline are controlled.

ICDs play an important role in CM to effectively communicate among the RPP contractors. The ICDs are the primary technical interface control tools that the ORP uses to formally establish and control the physical and functional interfaces between the two ORP Prime Contractors, i.e., the TFC and the PC.

CM is imposed through DOE O 430.1A, Life Cycle Asset Management and DOE/ORP-2000-12, Office of River Protection Life-Cycle Asset Management Policy. The RPP uses GPG-FM-012, 
Configuration and Data Management and ANSVEIA-649, National Consensus Standard for Configuration Management as guidance for the CM system.

Figure 5-2 shows the document hierarchy and process for CM.

Figure 5-2. Configuration Management Document Hierarchy and Process.

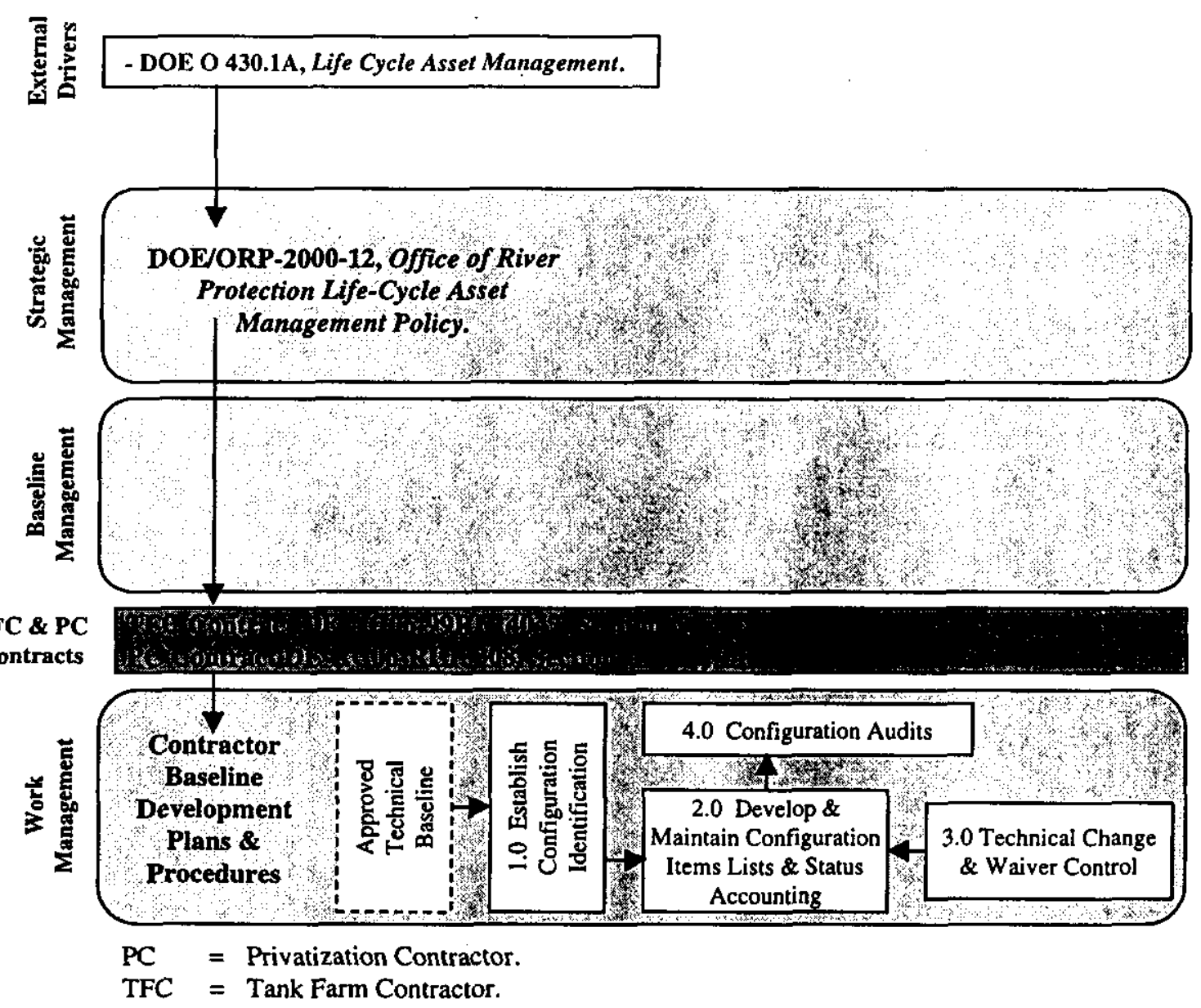

General Process - The general process is shown in Figure 5-2 and described as follows:

1.0 Establish Configuration Identification. The physical structures, systems, components, products, and processes (configuration items) are uniquely identified using a graded approach. Unique configuration identification relates the configuration of the items to technical baseline documentation, actual item configuration as acquired, and associated attributes. Proper identification and documentation relationships provide a known configuration of the operational systems to ensure safe operation and maintenance. In addition, configuration item identification is used to control the evolving design, procurement, and installation/startup of the physical systems and components. The RPP CM functions establish the configuration item identification criteria. The criteria enable CM early in the requirements development and design phases of the project. 
A feature of RPP CM is that the waste inventory (i.e., products) and the treatment process streams (i.e., production processes) are also subject to configuration management. These items include inventory of tank waste; residual waste contained in processing systems; and waste inventory that has leaked into, or been intentionally placed in, the soils in the tank farm areas. The waste is in a relatively dynamic condition with respect to volumes and chemical and physical characteristics. The waste inventory is characterized and documented in the "Best Basis Inventory" contained in the Tank Waste Information Network System database. The waste inventory is maintained under CM because these characteristics influence the waste processing operating sequence, process chemistry, and physical system design and safe operation.

2.0 Develop and Maintain Configuration Items Lists and Status Accounting. The configuration items lists and associated status accounting are an essential part of the RPP CM system and represent the life-cycle repository for the configuration items and their relationships. Immediately following approval, the configuration item entries are systematically captured (i.e., as configuration items are acquired or characterized during the life cycle of RPP) in their respective list or database along with related technical document information. Technical information includes, but is not limited to, documentation (e.g., drawings, design calculations, specifications), part numbers and serial numbers, operating and maintenance procedures, and change tracking. The lists are available to RPP participants who need to know the technical information to ensure integrity in the design evolution and provide for safe operations.

3.0 Technical Change and Waiver Control. The RPP CM system shares a common baseline change control process with RPP change control (see Section 5.3). The ICDs are central to maintaining control of changing technical interfaces between the ORP Prime Contractors. MOAs are central to maintaining control of interfaces between the RPP and other Hanford Site contractors. Section 5.7 describes interface management using ICDs, MOAs, and Integrated Product/Process Teams (IPT).

The RPP CM system maintains visibility of waivers (temporary changes to the approved baseline configuration) to the systems and components where adjustments to operating conditions may be necessary to ensure safe operation and maintenance.

4.0 Configuration Audits. The configuration established in configuration items lists and status accounting system is periodically audited against the technical baseline and actual configuration as installed. The CM process is also audited as part of the RPP QA function. The configuration audit ensures consistency among the requirements, installed configuration, and associated technical documentation to support the safe, efficient, and environmentally sound mission objectives of the RPP.

\subsection{BASELINE CHANGE CONTROL}

Changes to the approved RPP life-cycle baseline (i.e., technical, workscope, schedule, and cost) are managed through the baseline change control process. This process ensures all work being 
performed meets baseline requirements in accordance with established procedures and that impacts throughout the baseline are considered before actions are taken (see Figure 5-3).

Figure 5-3. Change Control Document Hierarchy and Process.

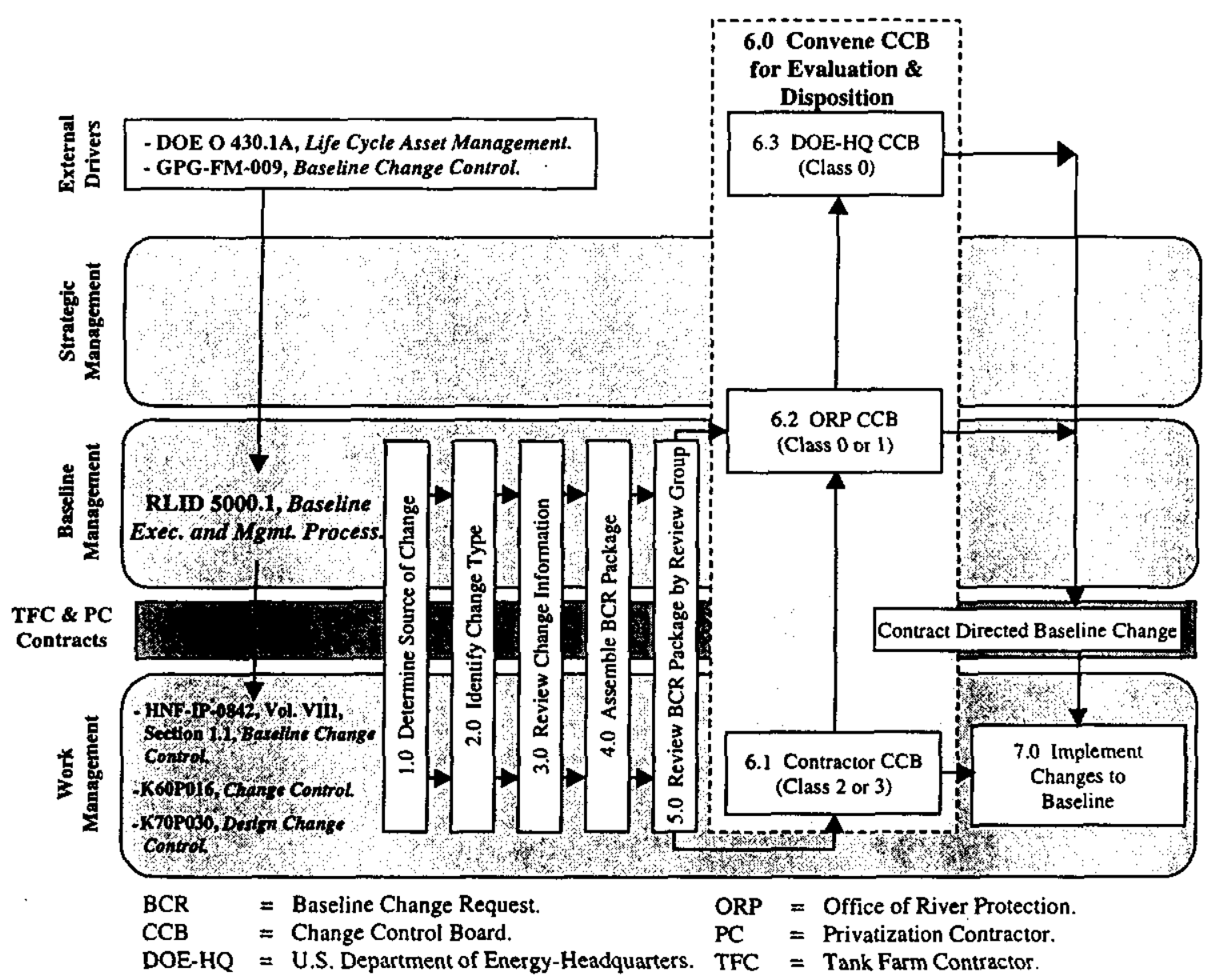

Baseline changes are processed and approved in accordance with the classification assigned to each change. There are four classifications of changes: Class 0 changes requiring DOE-HQ approval for major programmatic changes, Class 1 changes requiring ORP approval for major project changes, Class 2 changes requiring contractor approval for minor project changes, and Class 3 changes requiring management approval for administrative changes. An essential feature of the change control process is the existence of formal CCBs.

General Process - The basic process for controlling change follows. This applies to all TFC-managed work activities as defined in the TFC MYWP, and PC changes to ICDs. Other PC work activities follow the PC contract provisions for change control (see the PC contract [DE-AC06-RL13308]).

1.0 Determine Source of Change. The initiator of a change must determine the source of the change. Sources of change include change in technical, scope, schedule, or cost. 
Changes may be directed by DOE-HQ or the ORP. A change initiator may be DOE-HQ, the ORP, or the Prime Contractors.

2.0 Identify Change Type - Technical, Scope, Schedule, or Cost. The initiator of a change must make an initial assessment of the relevant changes to the technical, scope, schedule, and cost baseline via the WBS/project baseline summary (PBS) resulting from the proposed change. This assessment phase provides the initial screening of technical, scope, schedule, and cost impacts. If the change is technical, this also will invoke the CM process (see Section 5.2).

3.0 Review Change Information. The manager(s) responsible for the work affected by the change reviews the change information for the scope of the requested change, overall impact of the requested change, the justification of the change, and whether the change is an emergency.

4.0 Assemble BCR Package. The affected contractor (the TFC or the PC) assembles a $\mathrm{BCR}$ package. The $\mathrm{BCR}$ package consists of a determination of the change classification, the performance of an impact analysis, the completion of required information onto a BCR form, and the completion of supporting documentation.

5.0 Review BCR Package by Review Group. After the BCR package is assembled, a Joint Group and/or a Management Team review and evaluate it for thoroughness and procedural compliance.

5.1 For Class 1, 2, or 3 changes, a Joint Group, consisting of the affected Prime Contractors (the TFC or the PC) and ORP personnel, reviews and evaluates all changes before submittal to the appropriate CCB.

5.2 For Class 3 changes, a Management Team, consisting of the affected contractor personnel, reviews and evaluates the changes before submittal to the appropriate CCB.

6.0 Convene CCB for Evaluation and Disposition. The CCB to which the change is submitted reviews the change and determines the disposition of the change, i.e., approved, approved with comment, or not approved.

- 6.1 Contractor $C C B$. The Contractor $\mathrm{CCB}$ reviews and dispositions changes that are Class 2 and Class 3 . If the change submitted to the Contractor CCB is Class 0 or 1 , the Contractor CCB provides a recommended disposition and submits the change to the ORP CCB for further consideration.

6.2 ORP CCB. The ORP CCB reviews and dispositions Class 0 and 1 changes. If the change is Class 0 , the change package is submitted to DOE-EM for approval of the ORP disposition. If a change is Class 1, the ORP change control administrator prepares a transmittal letter notifying the affected contractor(s) of the CCB's decision. 
DOE/ORP-2000-06

Rev. 0

6.3 DOE-HQ CCB. The DOE-HQ CCB, run by DOE-EM, evaluates Class 0 changes and approves or disapproves the ORP CCB disposition.

7.0 Implement Changes to Baseline. The ORP authorizes implementation of approved Class 0 and 1 changes to the RPP life-cycle baseline. The implementation includes preparing and processing the necessary contract changes, if applicable. The affected contractor(s) implement the changes to their approved baseline. For the TFC, the approved MYWP is changed and for the PC, the Integrated Master Plan (PL-W375-G00002) is changed.

\subsection{CONTRACT MANAGEMENT}

The objectives and requirements of DOE O 435.1, Radioactive Waste Management, are implemented through DOE contractors. The ORP has direct responsibility for negotiating and managing all ORP prime contracts. Figure 5-4 shows this document hierarchy.

Management of these contracts involves the following:

- Specifying the products and product characteristics to be produced by the contractors

- Integrating and monitoring the performance of the contractors through Contracting Officers, Contracting Officer Representatives, and IPTs (see Section 5.7)

- Inspecting and accepting the products produced by the contractors and, where required, the production processes

- Authorizing payment for accepted products and performance.

The PC contract (DE-AC06-RL13308) is a fixed-price contract for privatized waste treatment facilities and services. Low-activity waste and high-level waste feed are provided by the DOE through the TFC to the PC for processing. The PC treats and immobilizes this waste in accordance with DOE specifications. The PC is paid for the immobilized waste products upon verification that the product meets DOE specifications. Administration of this contract is described in DOE/ORP-99-06, BNFL Contract Administration Plan.

The TFC contract (DE-AC06-RL13308) is a cost-plus-performance-based fee contract. In addition to requirements stated in the contract, the statement of work and performance agreements for this contract are described in the TFC MYWP. The MYWP is updated annually by the TFC and approved by the DOE. The performance agreements are negotiated annually to tie the fee to specific work requirements outlined in the MYWP. Upon approval of work completion, payment for costs incurred is authorized. Upon achievement of performance expectations, incentive fees are approved and the fee is authorized. 
DOE/ORP-2000-06

Rev. 0

Figure 5-4. Contract Management Document Hierarchy and Process.

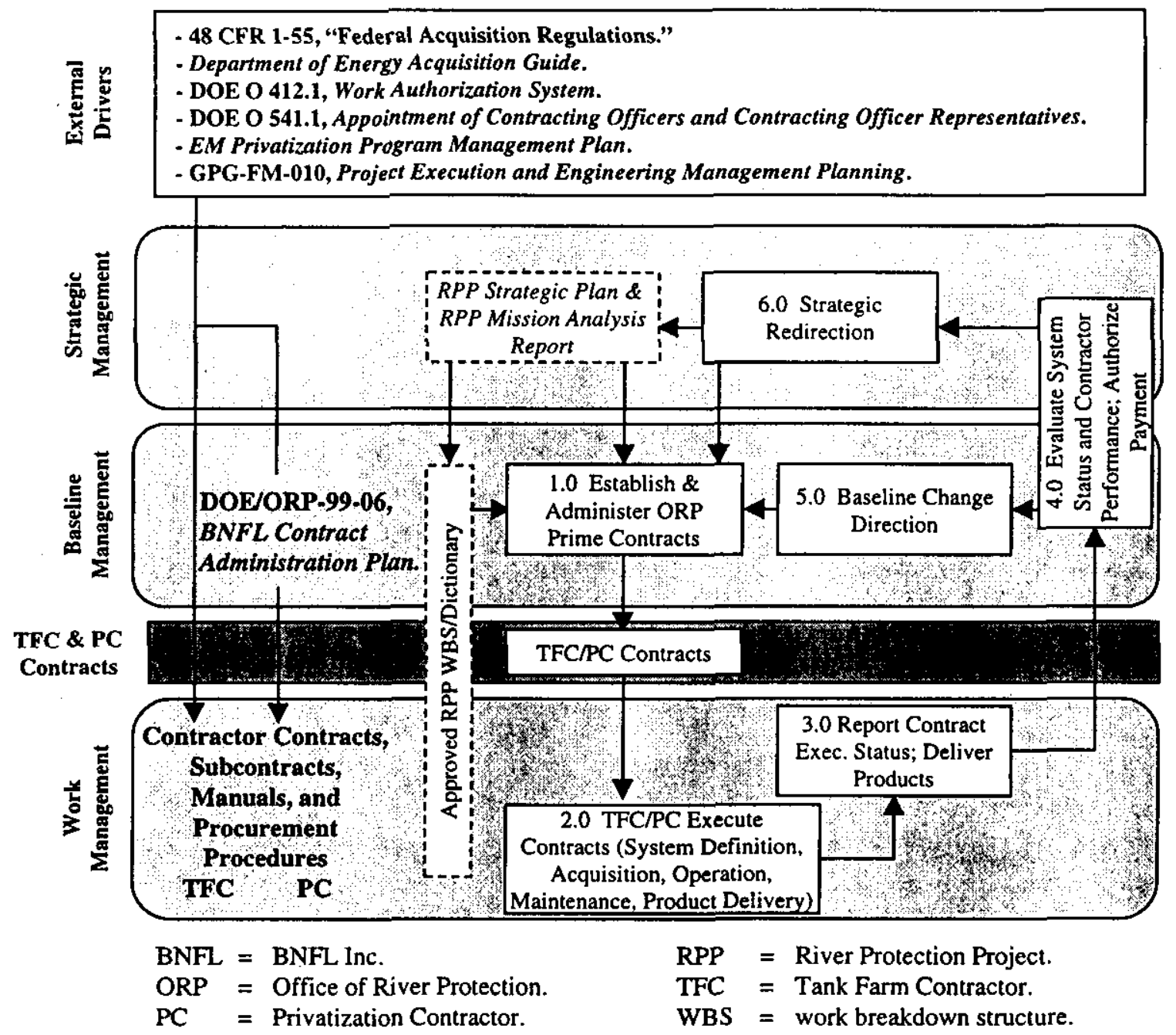

General Process - The general process is shown in Figure 5-4 and described as follows:

1.0 Establish and Administer ORP Prime Contracts. The ORP Prime Contractors and types of contracts are identified and negotiated in accordance with the direction described in the RPP Mission Analysis Report and DOE O 430.1A, Life Cycle Asset Management. The WBS and its dictionary contain the workscope for these contracts. Administration includes processing changes, to these contracts.

2.0 TFC/PC Execute Contracts. The TFC and PC contracts are currently in place and work is authorized and being performed. Other Site support work to these contractors is obtained under the MOA among ORP, RL, and DOE-EM.

3.0 Report Contract Execution Status; Deliver Products. Periodically (monthly, quarterly, and annually), baseline execution status and contractor performance of the contracted work are reported to the ORP (see Sections 5.5 and 5.6). Contractors deliver products (contract deliverables) as specified in the contracts. 
4.0 Evaluate System Status and Contractor Performance; Authorize Payment. The reported baseline status, contractor performance, and deliverables are analyzed and evaluated by the ORP Contracting Officer and Contracting Officer Representatives. Variances to the integrated baseline and contracted performance are identified and corrective action decisions made that have contracting implications. Upon verification of work and deliverables performance, contract payment is authorized.

5.0 Baseline Change Direction. Annually, a baseline update is processed to revise the baseline work to match Congressional funding levels (see Section 4.1). In some cases, it may be necessary to revise the contracts to direct corrective actions, e.g., revise work priorities or reassign workscope.

6.0 Strategic Redirection. In some cases, it may be necessary to revise contracts to implement changes in the RPP strategy because of technical considerations, major changes in funds availability forecasts, identification of a more effective contracting strategy, or stakeholder and ES\&H priority issues.

\subsection{PERFORMANCE MEASUREMENT}

The management and operating effectiveness of the RPP is measured through an ORP performance measurement system. The system requires quantitative measurement of progress toward results-oriented goals.

Performance measurement supports the total project goals and objectives established in the $R P P$ Strategic Plan and the fiscal year objectives established in the fiscal year project plans, i.e., the TFC MYWP and the PC Integrated Master Plan. Management control is exercised by evaluating the measured variance between planned and actual performance, identifying the root causes of adverse variances, and directing corrective actions to achieve the goals and objectives.

The ORP performance measurement system levies a consistent set of performance measurement goals on the TFC and the PC by way of their contracts. Figure 5-5 shows this document hierarchy. 
DOE/ORP-2000-06

Rev. 0

Figure 5-5. Performance Measurement Process.

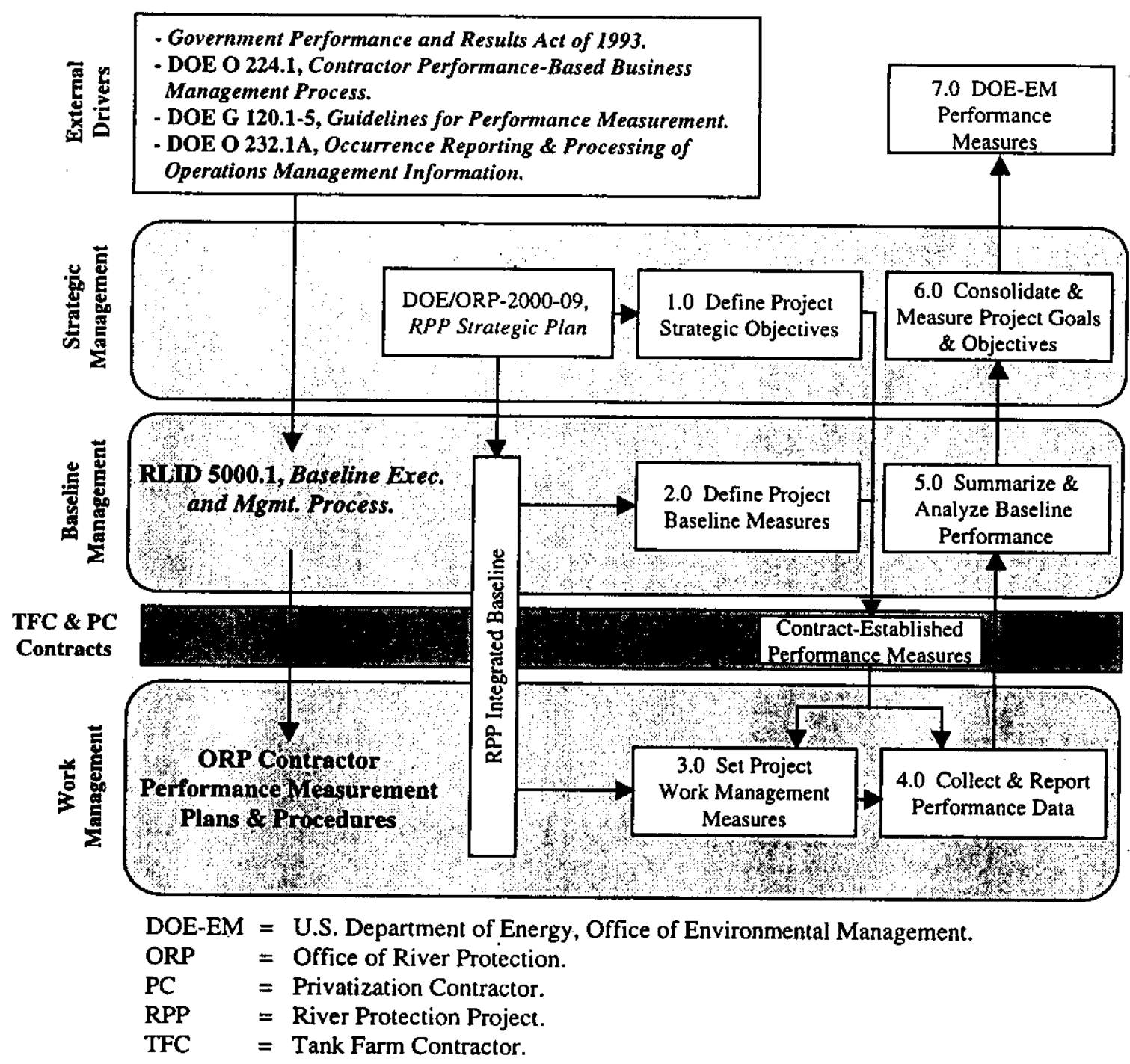

General Process - The general process is shown in Figure 5.5 and described as follows:

1.0 Define Project Strategic Objectives. Performance measures are established to measure cost, schedule, technical, operating, and ES\&H performance goals and objectives in the RPP Strategic Plan. Contractor efforts that substantially contribute to achieving these goals and objectives are developed into performance measures that become part of the performance-based contracts.

2.0 Define Project Baseline Measures. Quantitative performance measures are established to measure cost, schedule, and technical progress against the RPP integrated baseline. All contracts invoke the necessary reporting elements for measurement of these factors by the ORP. 
3.0 Set Project Work Management Measures. The ORP Prime Contractors establish internal performance measures as appropriate for good management practice in accordance with the intent of DOE O 430.1A.

4.0 Collect and Report Performance Data. Performance data are acquired at the detail work level, transformed as necessary, and summed through the WBS and organization levels for analysis. The Prime Contractors periodically submit the baseline and strategic performance reporting elements to the ORP for summarization, analysis, and further reporting.

5.0 Summarize and Analyze Baseline Performance. The cost, schedule, and technical status is measured against baseline requirements and reported monthly.

6.0 Consolidate and Measure Project Goals and Objectives. The ORP consolidates the measures into a monthly performance report with respect to the strategic goals and objectives. The report is submitted to DOE-HQ and stakeholders.

7.0 DOE-EM Performance Measures. Specific RPP indexes of project performance are developed and submitted to DOE-EM for inclusion in the DOE-HQ consolidated performance reports. The reports are submitted to the Secretary of Energy and Congress in accordance with the requirements of the Integrated Planning, Accountability, and Budgeting System (see DOE's Integrated Planning, Accountability, and Budgeting System Handbook).

\subsection{INFORMATION AND REPORTING}

Information management is a fundamental element in the ORP and contractor team management structure. It provides a basis for reliable and accurate information used to make appropriate decisions about the project.

The Information Resource Management (IRM) function within the ORP provides overall IRM planning and policy functions in accordance with the law, and provides high-level technical direction and integration of ORP IRM components. The function emphasizes development and implementation of information management standards and systems that facilitate disciplined management of project activities. For a complete understanding of the IRM responsibilities, see DOE/ORP-2000-13, Office of River Protection/Information Resource Management Policy.

The RPP requires, the collection and reporting of many types of data. These data must be consolidated and transformed into meaningful information for management purposes and to meet several legal requirements. These data have been broadly classified into management, regulatory, and technical data. The technical and management data and information requirements are discussed in Sections 4.0 and 5.0. The regulatory data and information are discussed in Section 6.0.

The gathered data are controlled and deposited in various hard copy and electronic repositories. Depending on the type and detail level of the data, contractors maintain the data in the 
repositories in accordance with DOE/ORP-2000-13. Figure 5-6 shows the hierarchy of documents for data management.

Figure 5-6. Information and Reporting Document Hierarchy and Process.

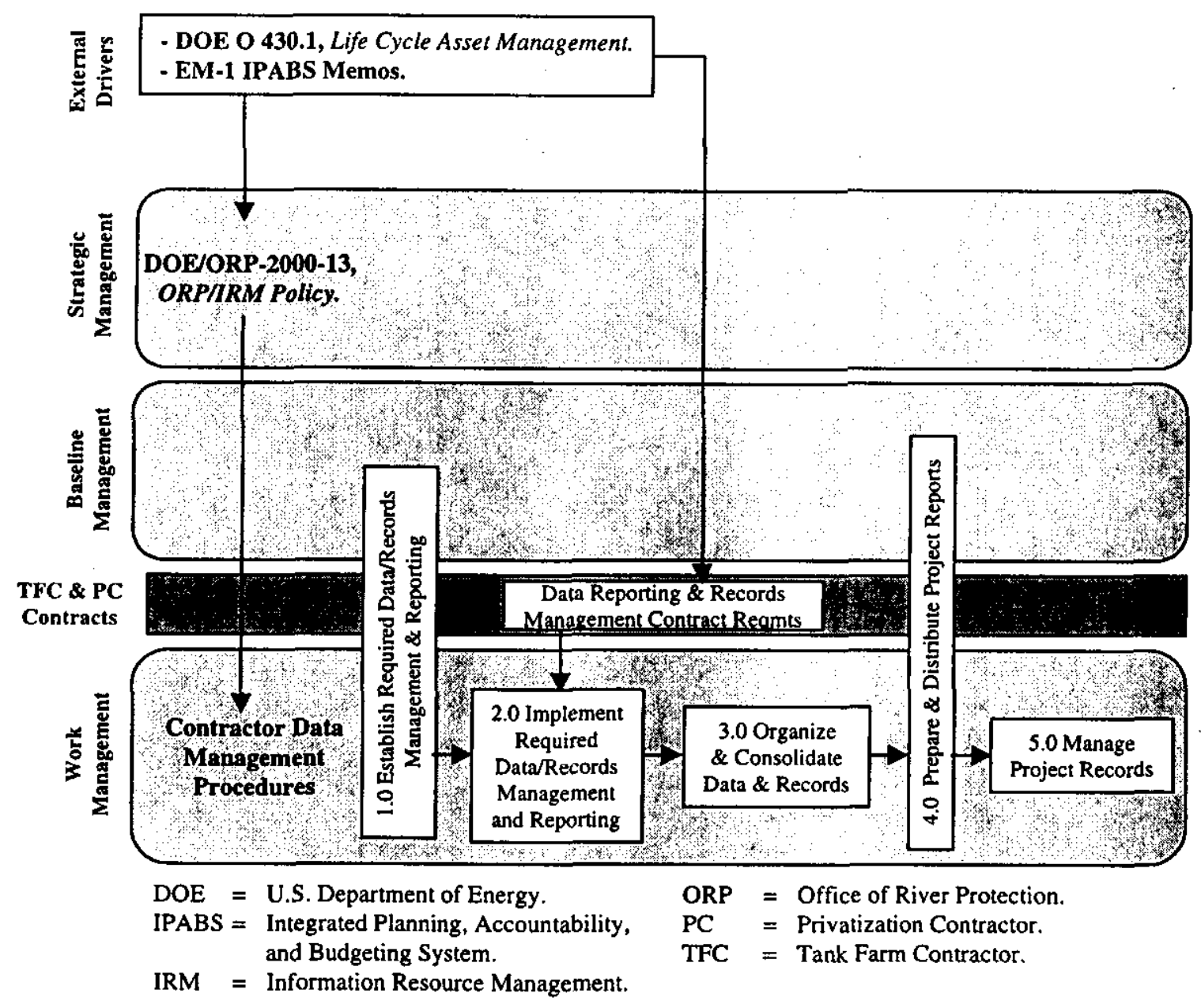

General Process - The general process is shown in Figure 5-6 and described as follows:

1.0 Establish Required Data/Records Management and Reporting. The ORP, in conjunction with the TFC and the PC, defines and describes the project data and records management and information reporting requirements based on legal, DOE-HQ, and project needs. The applicable requirements are invoked in the TFC and the PC contracts. The ORP directs development and maintenance of an information architecture that maintains and controls information and data requirements, including the RPP web pages for electronic access to the data.

2.0 Implement Required Data/Records Management and Reporting. The information architecture development process is described in contractor information management procedures. Drivers from DOE-HQ, contract requirements, and contractor procedures describe the data, reports, source for information requirements, 
originator, recipients, repository, update frequency, and other essential elements associated with the data and records that must be managed and reported to the ORP. These also identify and describe reports that the ORP produces.

3.0 Organize and Consolidate Data and Records. Upon production of the data, the contractor organizes and consolidates the data for ORP and contractor reporting. The data used by the ORP are generally extracted directly from the contractors' repositories. Project records are transferred to the appropriate secured repository where necessary. This activity interfaces, and operates in conjunction, with the technical, management, and regulatory processes described in Sections 4.0, 5.0, and 6.0 .

4.0 Prepare and Distribute Project Reports. Using the collected data, the contractors and the ORP prepare and distribute technical, management, and regulatory reports in accordance with the requirements specified in the drivers and contracts.

5.0 Manage Project Records. Project records have special management requirements pertaining to security, access, and retention period. The ORP contractors manage these records in accordance with the contract requirements. The ORP conducts periodic surveillance and audits of the contractors' Records Management Systems and records.

\subsection{INTERFACE MANAGEMENT}

The interface management function ensures that interfaces to and within the RPP are recognized, established, and controlled, and optimal solutions across interfaces are provided. These interfaces include those involving the following:

- Other federal entities (e.g., between the ORP and Congress, DOE-HQ, RL, DNFSB, and the national geologic repository)

- Regulatory agencies and Boards (e.g., between ORP and Ecology, Washington State Department of Health, EPA, and the U.S. Nuclear Regulatory Commission)

- Major contractors (e.g., between ORP and the PC and the TFC)

- Other contractors (e.g., between the TFC and Project Hanford contractors)

- Stakeholders (e.g., between ORP and the Hanford Advisory Board, local and state governments, business and financial organizations, labor representatives, Tribal Nations, and special-interest groups).

Management of the RPP interfaces, including roles and responsibilities, is described in detail in an RPP interface management plan; an overview is presented here.

The interface management function evaluates the interfaces to ensure that management control exists for the interfaces and that the controls are appropriate. The ORP may use any of several 
vehicles to ensure that interfaces are managed. These interface management vehicles can include, but are not limited to, contracts, laws, court agreements, codes and standards, MOAs, Memoranda of Understanding (MOU), ICDs, or letters. Figure 5-7 identifies the various interfaces to the ORP. The RPP will continue to evaluate these interfaces to ensure that control mechanisms exist and that the controls are effective. Section 3.3 further describes these interfaces.

Figure 5-7. Office of River Protection Interfaces.

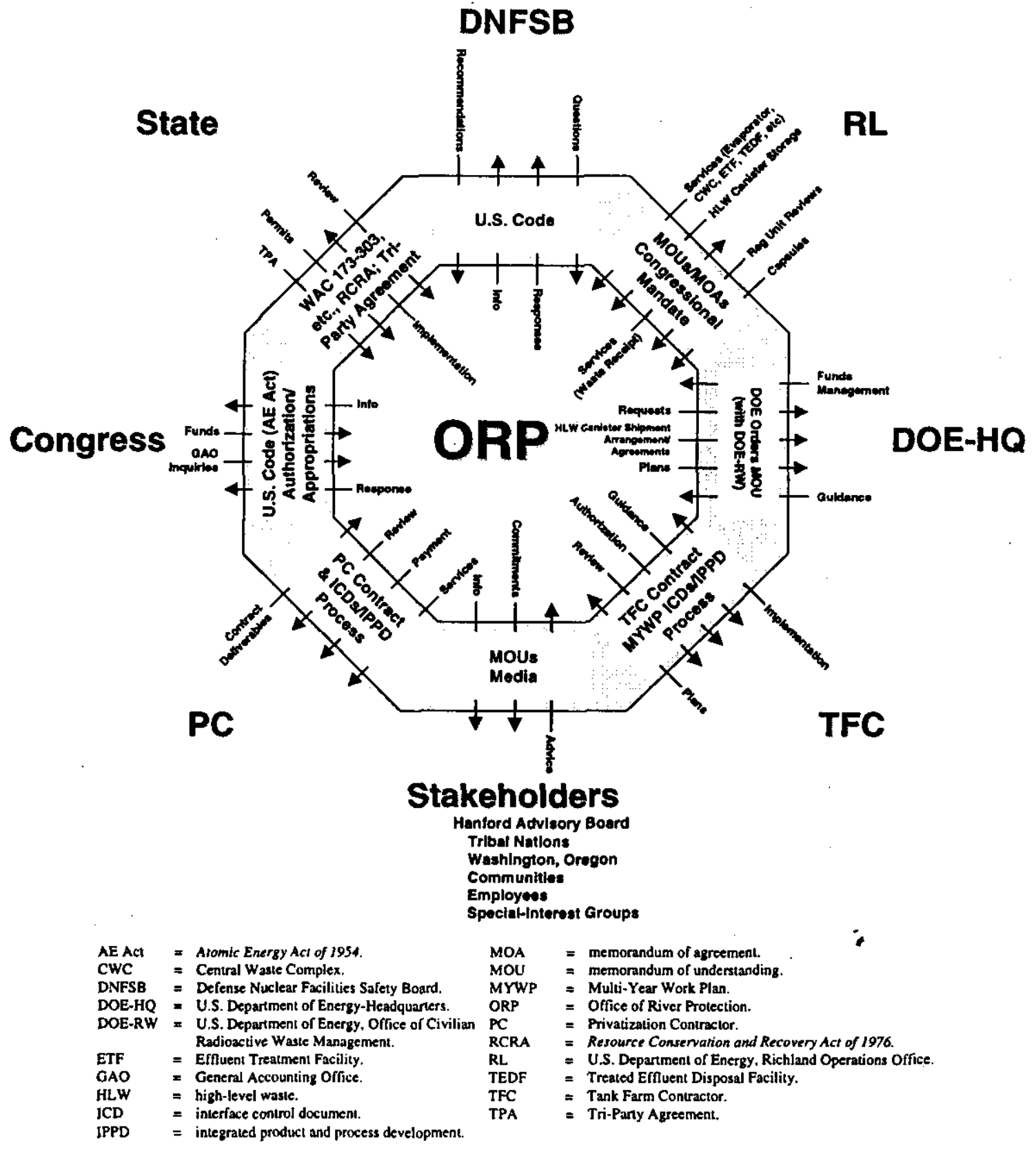


The ORP uses several tools to manage its interfaces with those contractors performing the work. The three major tools include IPTs, ICDs, and MOUs/MOAs.

IPTs - Each IPT consists of ORP, the TFC, and the PC representatives having expertise in the interface subject matter. Five major IPTs have been established for interactions with the PC and the TFC. They include the subject areas of Project Management; Interface; Business and Finance; Technical; and Safety, Health and Environment. Figure 5-8 depicts the relationships of these IPTs. The IPTs are managed to provide optimal solutions across the interfaces; promote contractor innovation and accountability for deliverables and services; minimize formal reporting and other administrative requirements; provide for integration of contractors' activities by linking interfaces; and provide contractors with focused, timely access to information and organizations required to meet their performance obligations. The process will be extended to other interfaces.

Figure 5-8. Integrated Product/Process Teams.

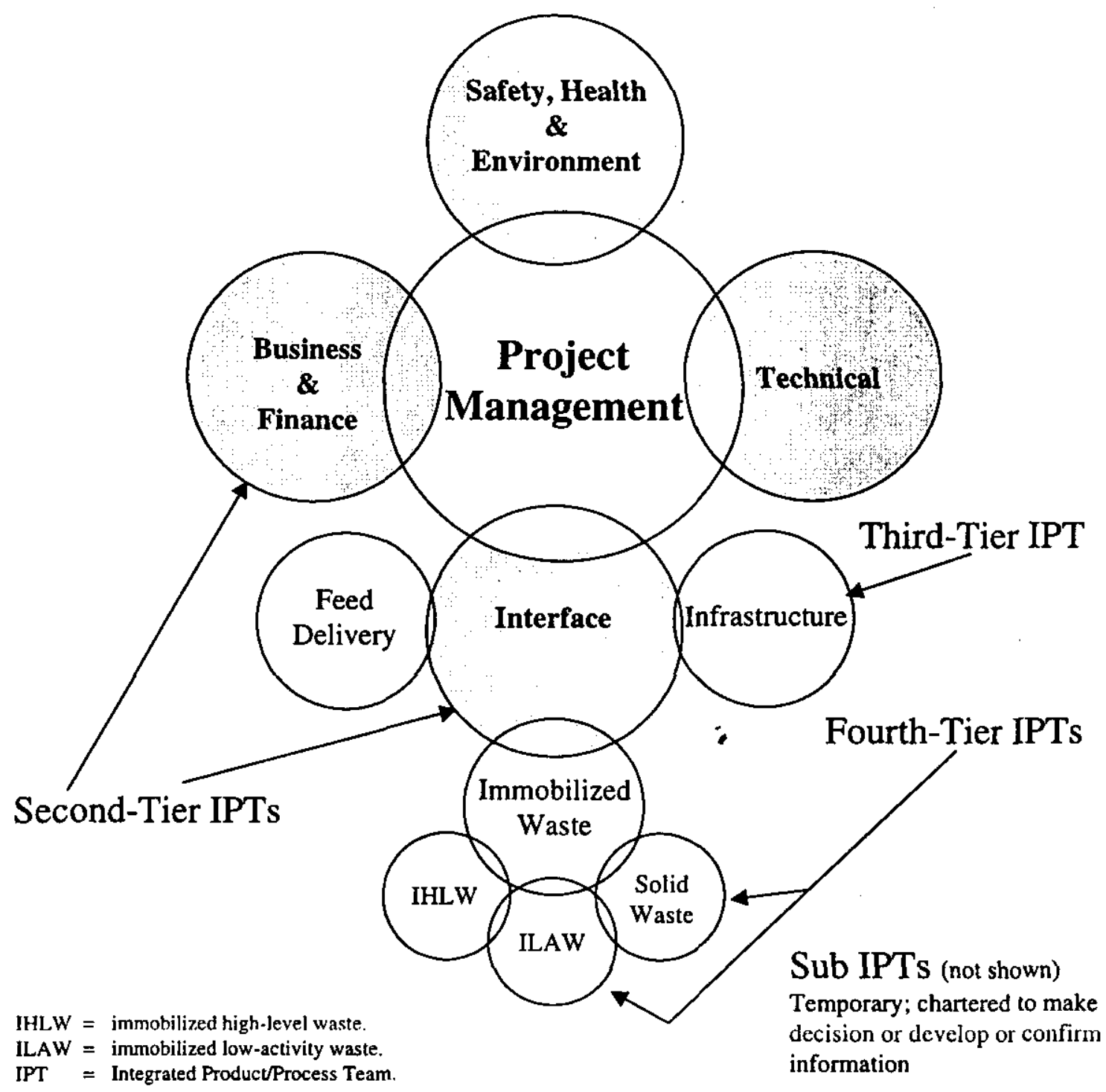


ICDs - The ICD is one of the key methods for integrating and managing the multiple interfaces that exist among the PC, the TFC, and the DOE at the Hanford Site. The ICDs are a component of the PC contract and the RPP's technical baseline. ICDs are approved and signed by the DOE and the PC. Twenty-three ICDs have been written to define the technical details of the interfaces among the ORP and its contractors, and are documented in the PC contract. Figure 5-9 depicts these interfaces. Other interface control mechanisms include bridge schedules, issues lists, and configuration controls. Additional ICDs will be established for other interfaces as needed.

Figure 5-9. Interface Control Documents.

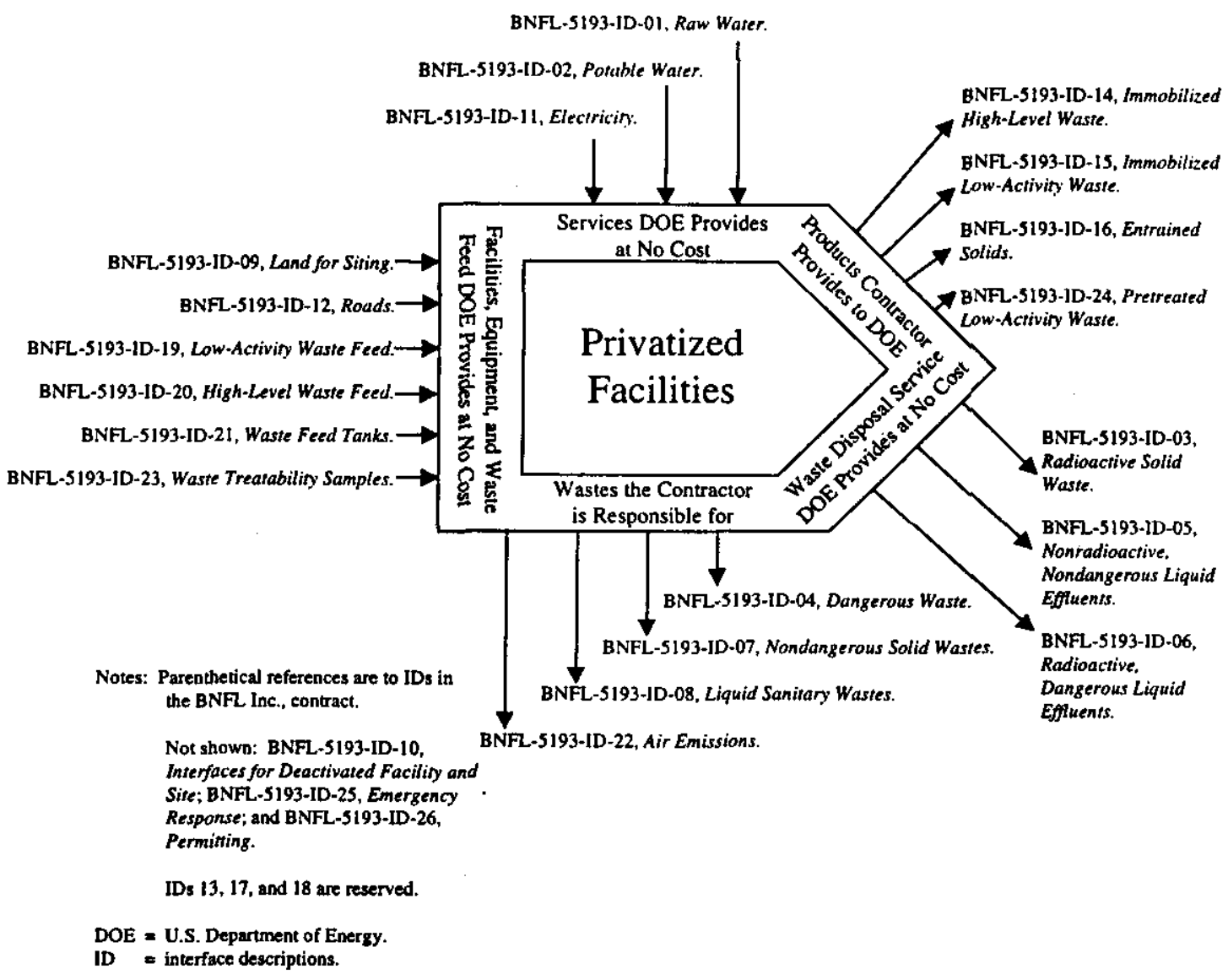

MOUs/MOAs - MOUs and MOAs define the working relationships, obligations/commitments, and roles/responsibilities and authorities/accóuntabilities of key RL, ORP, and DOE-HQ organizations supporting the mission. Generally, MOUs or MOAs are established and monitored with organizations responsible for delivering a service or product to the project. Points of contact within these organizations are identified and work with designated RPP staff in developing and monitoring the MOU or MOA. Monitoring occurs through regularly scheduled meetings of the points of contact. 


\subsection{WORK AUTHORIZATION}

Work Authorization authorizes the commitment of resources and execution of the work described in the approved RPP integrated baseline for the specified time, usually a fiscal year. Formal work authorization is required under DOE O 412.1, Work Authorization System and is implemented in the ORP using the guidelines established by RLID 5000.1, Baseline Execution and Management Process. The ORP and the contractor sign the Work Authorization. Figure 5-10 shows the document hierarchy.

Figure 5-10. Work Authorization Document Hierarchy and Process.

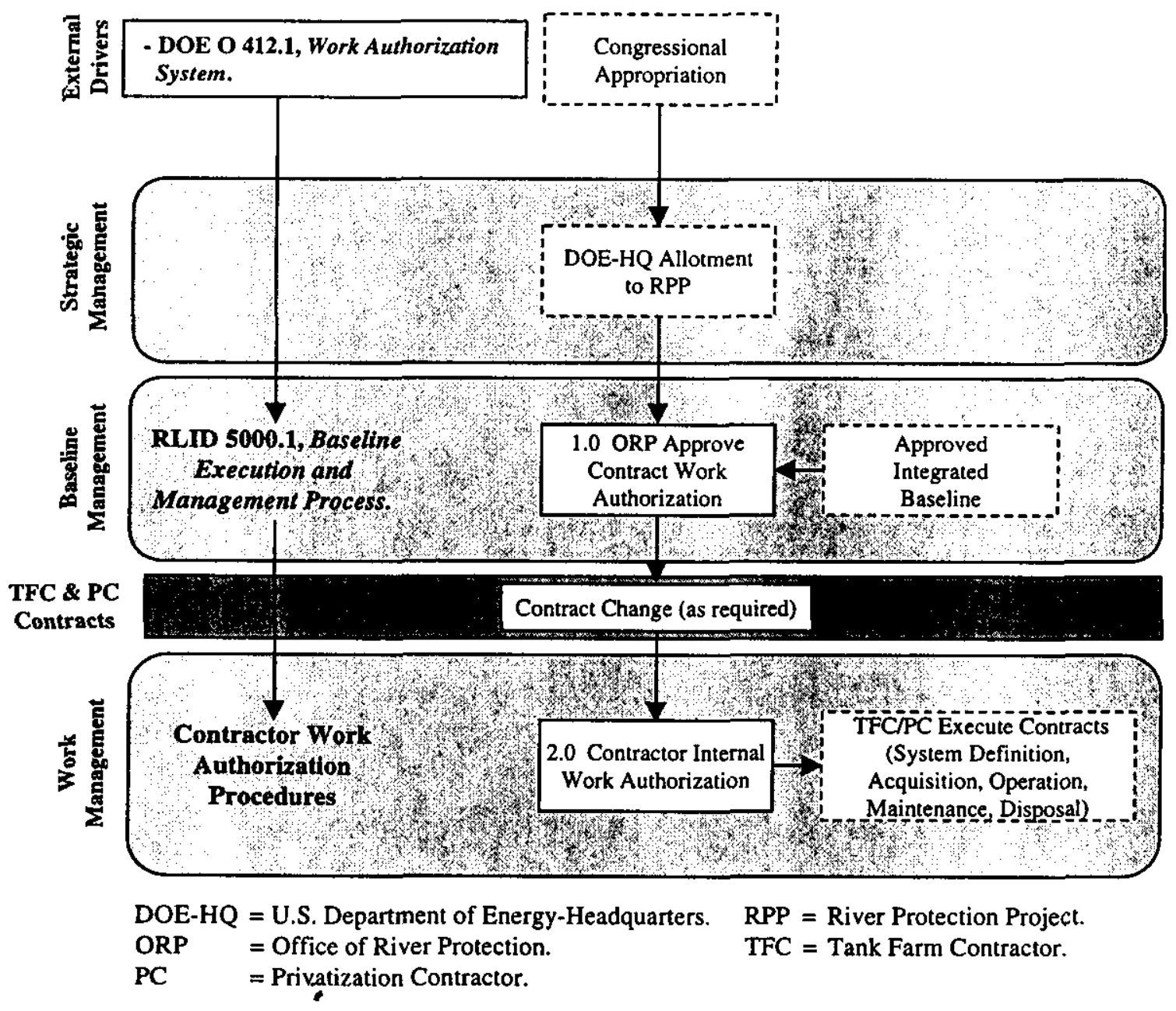

General Process - The general process for work authorization is shown in Figure 5-10 and described as follows:

1.0 ORP Approve Contract Work Authorization. Upon notification from DOE-HQ that funding has been allocated to the RPP, the ORP authorizes work initiation based on an approved integrated baseline. The integrated baseline is approved by the ORP through the TFC MYWP and the PC Integrated Master Plan. Work is authorized at the PBS level for expense-funded activities. The PBS level is at Level 3 of the WBS 
contained in the approved integrated baseline. Each capital line item is authorized separately within the applicable PBS. The ORP prime contracts are updated in accordance with the approved workscope and signed by the contractors.

2.0 Contractor Internal Work Authorization. Upon mutual approval of the contracted workscope for the approved funding period, the contractors authorize performance of the work using their internal work authorization processes.

\subsection{WORK MANAGEMENT}

Work management, in the context of this PMP, pertains to managing at the work performance level by the ORP Prime Contractors. While the ORP does not manage the work at this level, the contractor procedures incorporate the work management policy requirements contained in DOE regulations, policies, and requirements as invoked in their respective contracts. The DOE requires that work be planned and authorized, with appropriate consideration for the hazards involved; performed safely by trained and qualified personnel with established controls; and include verification that the work was properly accomplished with effective feedback to improve the work process.

\subsection{RISK MANAGEMENT}

Programmatic risk management is an integral part of project management. The RPP has established a standardized, structured process for identifying, assessing, and handling risks. This process manages risk proactively from project initiation to completion. This results in decreased likelihood and extent of potential cost overruns, schedule delays, and compromises in system quality.

Two types of risks are identified, and processes to manage each are established. Project baseline risks are uncertainties in the cost, ability to perform scope, and schedule of specific activities in the integrated project baseline. These risks are analyzed quantitatively (particularly for potential cost and schedule impacts), and managed by project managers responsible for the specific workscope activities. Organizational risks are typically more qualitative and broad, and are not directly tied to impacts on specific project baseline activities. Organizational risks may include stakeholder concerns, Tribal Nation issues, political concerns, and funding or labor problems.

As shown in Figure 5-11, the ORP has established ORP-6126, RPP Programmatic Risk Management Policy, which establishes the top-level requirements for risk management. The RPP Programmatic Risk Management Plan (ORP-6127) defines the implementation of this policy. Individual contractors are responsible for their own risk management procedures, consistent with the Policy and the Plan. 
DOE/ORP-2000-06

Rev. 0

Figure 5-11. Risk Management Document Hierarchy and Process.

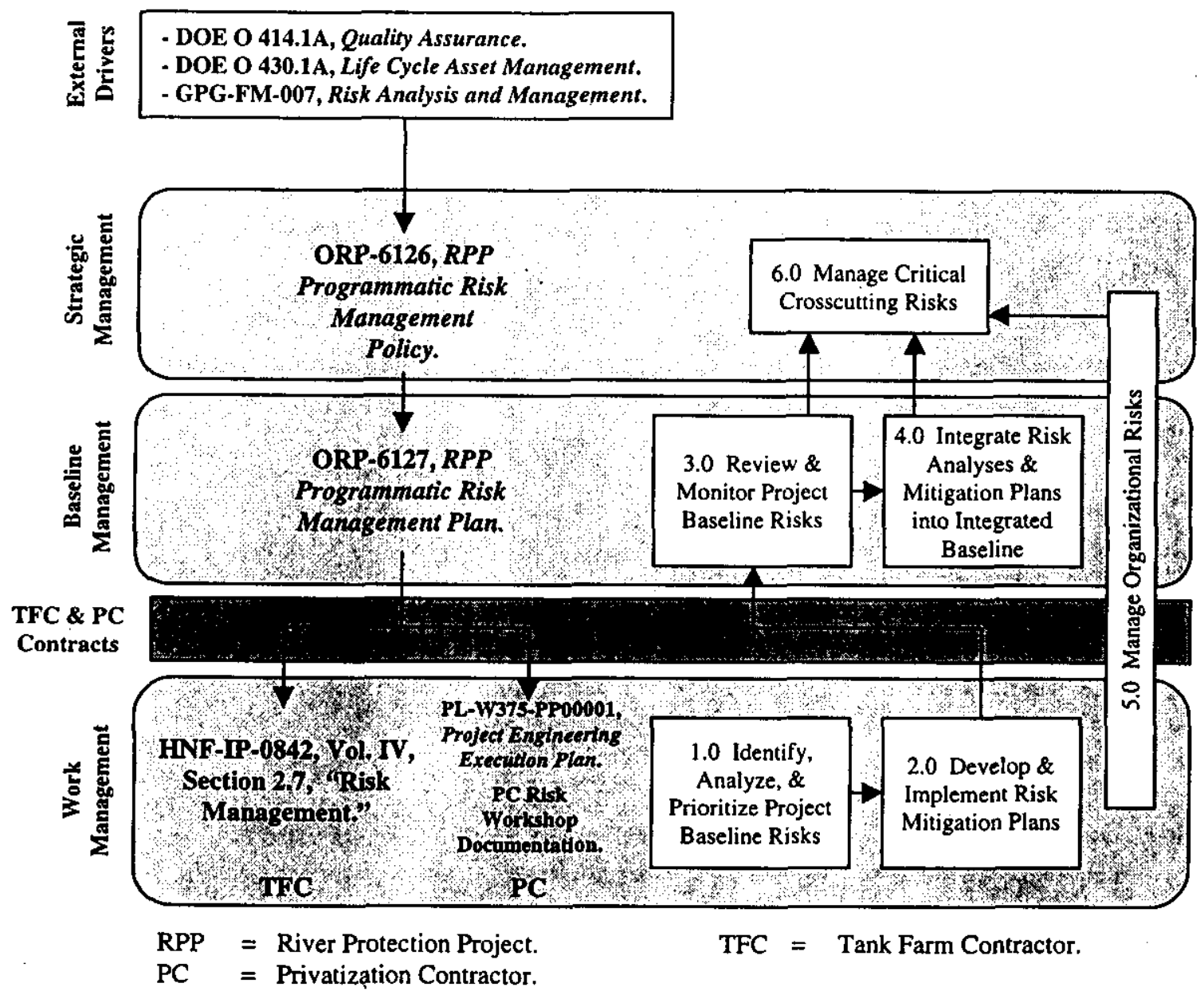

General Process - The general process is shown in Figure 5-11 and described as follows:

1.0 Identify, Analyze, and Prioritize Project Baseline Risks. Cost and schedule risks for baseline activities are identified, analyzed, and prioritized as described in ORP-6127, RPP Programmatic Risk Management Plan. The approach is built on a structured and proven process for systematically developing probabilistic estimates of uncertainty in project baseline cost and schedule estimates. These estimates are used in Monte Carlo simulations to produce descriptions of overall project cost and schedule uncertainty. The probabilistic assessments for the cost and schedule of baseline activities are determined by specific consideration of the technological uncertainty; the uncertainty in workscope definition; and the uncertainty in dependency on other sites, organizations, and companies. The underlying principles for the approach are the need for high-quality inputs into the analysis, and the use of the analysis results to diagnose and prioritize the most significant contributors to uncertainty for further risk management actions. 
2.0 Develop and Implement Risk Mitigation Plans. Risk mitigation plans for highpriority risks are developed. These plans define the responsibility for scope, schedule, and cost of the mitigation actions. Required actions are incorporated into the project baseline through change control.

3.0 Review and Monitor Project Baseline Risks. The risk analysis and status of risk mitigation plans are reviewed and monitored as part of the project control and reporting process.

4.0 Integrate Risk Analyses and Mitigation Plans into Integrated Baseline. As part of project integration, risk analyses and mitigation plans for the workscope of individual contractors are integrated to provide a comprehensive and consistent representation of RPP risk and mitigation plans. This integration may involve balancing risks across baseline activities.

5.0 Manage Organizational Risks. Organizational risks are assessed more qualitatively without assessments of direct impacts on specific baseline activities. They are managed using risk management lists that identify risks, management actions, responsibilities, and schedules; and are regularly monitored for progress.

6.0 Manage Critical Crosscutting Risks. Project baseline risks and organizational risks that must be managed across multiple line/contractor organizations, and that are critical in terms of impact, urgency, and need for senior management attention, are identified and elevated to the crosscutting critical risk management list. Regular meetings of ORP and contractor managers establish risk management plans and monitor progress on these risks.

\subsection{CONSTRUCTION PROJECT MANAGEMENT}

Construction projects within the scope of RPP consist of Major System Projects and Other Projects. In general, construction projects are a unique effort that has a defined start and end point, undertaken to develop a facility or system and contain interdependent activities that are planned to meet the RPP mission. The scope of these construction projects includes planning and execution of the non-privatized portion of the RPP construction and modification activities. Construction projects with a total project cost of $\$ 400$ million or greater, or as designated by the Deputy Secretary, are managed as a Major System Project. All construction projects with a total project cost of less than $\$ 400$ million and not designated as a Major System project, including line-item projects, general plant projects, and capital equipment, whether funded by capital or operating funds, are managed as an Other Project.

\subsubsection{Project Baseline and Contract Management}

A construction project management manual is the primary document used to manage the planning and execution of construction projects. The manual provides the basis for the implementation of requirements for the contract management and contract administration of the TFC construction projects. The manual supplements the PMP, is consistent with the basic 
principles of DOE O 430.1 A, and implements the additional guidance provided by the Joint Program Office Direction on Project Management. Construction project procedures also have been prepared to provide detail requirements for the consistent implementation of the manual. The manual and procedures are revised or updated as needed to support the efforts of the DOE-HQ Office of Engineering and Construction Management and the Assistant Secretary, Environmental Management to streamline and improve the management of DOE's engineering, construction, and environmental projects.

\subsubsection{Construction Project Work Management}

Construction project work management is implemented through RPP-6017, Draft Project Execution Plan for the Tank Farm Contractor. The Plan is contractor- and ORP-approved, construction-project-specific, and prepared as required for each construction project. The Plan is developed using DOE O 430.1 and the guidance contained in Good Practice Guide GPG-FM-010, Project Execution and Engineering Management Planning. Typically, the Plan:

- Provides the project scope, project objective, and method for performing the work and achieving objectives

- Establishes the work definitions, the cost goals, schedule constraints, and roles and responsibilities for project planning and execution

- Defines how the project will be controlled and documented

- Identifies procedures and detail plans for the planning and execution of the construction project.

\subsection{COMMUNICATIONS AND STAKEHOLDER/PUBLIC INVOLVEMENT}

Communication is an essential element to the success of the RPP. This project management function includes external activities associated with local, regional, and national contacts during interactions with the public, stakeholders, Tribal Nations, and the media.

The Office of Communications maintains an overall communication plan covering various aspects of the ORP's communications and outreach efforts. As progress is made on the RPP, aspects of the ORP's communication activities will be modified to meet çhanging needs, and those will be reflected in communication activities.

The Office of Communications coordinates communications efforts with the ORP and other DOE staff, the Hanford Advisory Board, Tribal Nations, Hanford communities, local media, and other local and regional interested parties. Ongoing activities involve essential audiences such as the Northwest Congressional delegation, regulators, Tribal Nations, state entities, Congressional and appropriation committees, labor organizations, DOE-HQ, and regional media. 
As a project control and interface management element of the ORP, the Office of Communications ensures that in addition to the minimum, legal requirements for stakeholder involvement activities, the RPP is doing as much as is appropriate to ensure successful communication with key stakeholders throughout the life of the RPP.

Specific activities of the Office of Communications include the following:

- Interacting with the Hanford Advisory Board and associated committees and members via regularly scheduled meetings and conducting discussions through presentations at meetings, public question and answer sessions, and one-on-one discussions

- Coordinating and implementing public involvement efforts with Ecology and the EPA for Tri-Party Agreement and permitting issues, and providing public opportunities to comment on key project decisions

- Maintaining a web site on the Internet, and seeking innovative techniques to effectively communicate with diverse stakeholder and Tribal Nation interest groups

- Coordinating with the media to issue timely information; developing and issuing press releases; arranging and conducting media events, such as editorial boards and press conferences; and responding to inquiries from the media

- Keeping DOE management and spokespersons apprised of issues of greatest concern to interested audiences by providing current, accurate information to enhance quality interaction and meaningful dialogue

- Integrating project public relations activities with RPP and RL and complying with ORP communication protocols and requirements.

Figure 5-12 shows the document hierarchy for ORP communications. 
DOE/ORP-2000-06

Rev. 0

Figure 5-12. Communications Hierarchy.
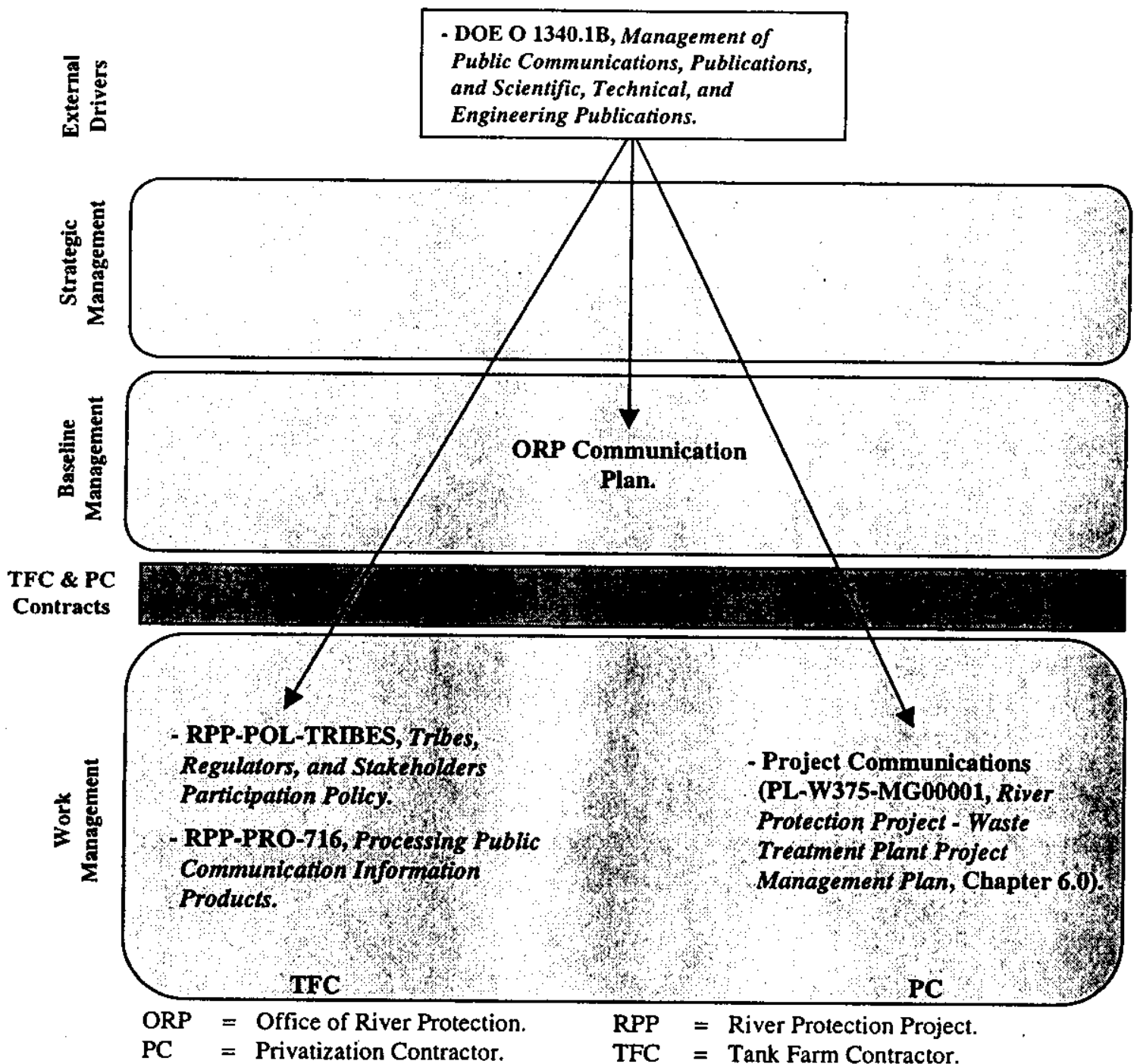


\subsection{COMPLIANCE}

The RPP is committed to conduct its business in compliance with requirements and to be responsive to the changing regulatory climate and practices. This section highlights selected areas of interest for discussion and does not attempt to cover every compliance topic that a project of this magnitude might encounter. The topics are discussed from an RPP perspective and describe the mechanisms and documents that demonstrate compliance for the ORP and its two Prime Contractors: the TFC and the PC. Compliance areas of utmost importance in the RPP include the following:

- ISM

- Environmental management

- Occupational safety and health

- Nuclear safety

- Radiological safety

- QA

- Emergency management

- SAS.

An essential element of the RPP compliance strategy of the DOE was to charter a dedicated Office of Safety Regulation (Regulatory Unit) for the RPP PC. The aim of the DOE is to establish a regulatory environment that will permit privatization to occur on a timely, predictable, and stable basis. In addition, attention to safety must be consistent with that which would result from regulation by external agencies. Because external regulation of DOE safety remains under consideration for some future date, regulations were developed that would permit a seamless transition to external regulatory agencies. The DOE is patterning its regulation of the PC to be consistent with that of the U.S. Nuclear Regulatory Commission for radiological and nuclear safety. For industrial hygiene and safety, regulation is consistent with that of the Occupational Safety and Health Administration.

The Manager, RL has responsibility and authority for safety regulation for the PC. The Manager, RL has assigned safety regulatory authority to the RL Director of the Regulatory Unit (the RPP privatized regulatory official). The regulatory authority of the regulatory official is exclusive to the regulation of the PC. The regulatory official is the formal point of execution for safety regulation of the $\mathrm{PC}$.

\subsection{INTEGRATÉD SAFETY MANAGEMENT}

Significant hazards and risks are associated with the RPP life-cycle workscope making it imperative to establish and implement a comprehensive ES\&H management system capable of managing complex hazards, risks, and issues. DOE P 450.4, Safety Management System,'

\footnotetext{
${ }^{1}$ Throughout this document, the term "safety" is used synonymously with the term "environment, safety, and health" to encompass protection of the public, the workers, and the environment.
} 
establishes the basis for just such an ISM System. The objective of the ISM System is to systematically incorporate ES\&H requirements into the management and work practices at all levels to DO WORK SAFELY using mechanisms that involve and result in continuous improvement. Safety will not be considered "in addition to" the work itself. The integration of safety management into daily work activities shifts the focus from incorporating safety as a support function to building safety into actual work processes to direct, plan, analyze, perform, assess, and improve the safe and efficient conduct of work at all levels of the project. This is accomplished by implementing the seven ISM principles:

- Line management responsibility for safety

- Clear roles and responsibilities

- Competence commensurate with responsibilities

- Balanced priorities

- Identification of safety standards and requirements

- Hazard controls tailored to work being performed

- Operations authorization.

Other DOE policies and guidance documents support DOE P 450.4 as illustrated in Figure 6-1.

ORPPD 450.1, River Protection Project Environment, Safety, and Health Policy, establishes the RPP policy on ISM and directs the implementation of ISM throughout the RPP workscope, lifecycle phases, and organizational function and through contracts to the RPP contractors. ORPPD 450.1 directs implementation of the ISM through the five core functions and seven principles established in DOE P 450.4. The five core functions, shown in Figure 6-1, are (1) define the scope of work, (2) analyze hazards, (3) develop and implement controls, (4) perform work, and (5) provide feedback. Figure 6-1 illustrates the ORP giving direction to the contractors and the feedback, which is a vital part of the ISM System. The ORP has also developed ORPM 450.1, RPP Integrated Environment, Safety and Health System Description. This Manual provides a description of ORP's approach to the integration of ES\&H requirements and controls into the process of directing, planning, and conducting work to effectively protect the workers, the public, and the environment. The Manual provides guidance and mechanisms concerning the implementation of the seven principles by the ORP and defines and clarifies integration and interface among organizational functions. The FRAM establishes the ORP functions, responsibilities, authorities, and clear lines of responsibilities for the project.

ISM development and implementation are required in the TFC contract through Department of Energy Acquisition Regulation (DEAR) Clause 970.5204-2, "Integration of Environment, Safety, and Health into Work Planning and Execution" (see 48 CFR). The DEAR Clause requires the contractor to develop an ISM System that is consistent with DOE P 450.4 and to complete a Phase 1 verification process on the contractor's ISM system description. The TFC completed the ISM Phase 1 verification in October 1998. The DEAR Clause also requires the contractor to complete Phase 2 verification on the implementation of the ISM system description, which the TFC completed in June 1999. The TFC's ISM System is documented in RPP-MP-003, Integrated Environment, Health, and Safety Management System Description for the Tank Farm Contractor. 
Figure 6-1. Integrated Safety Management Document Hierarchy.

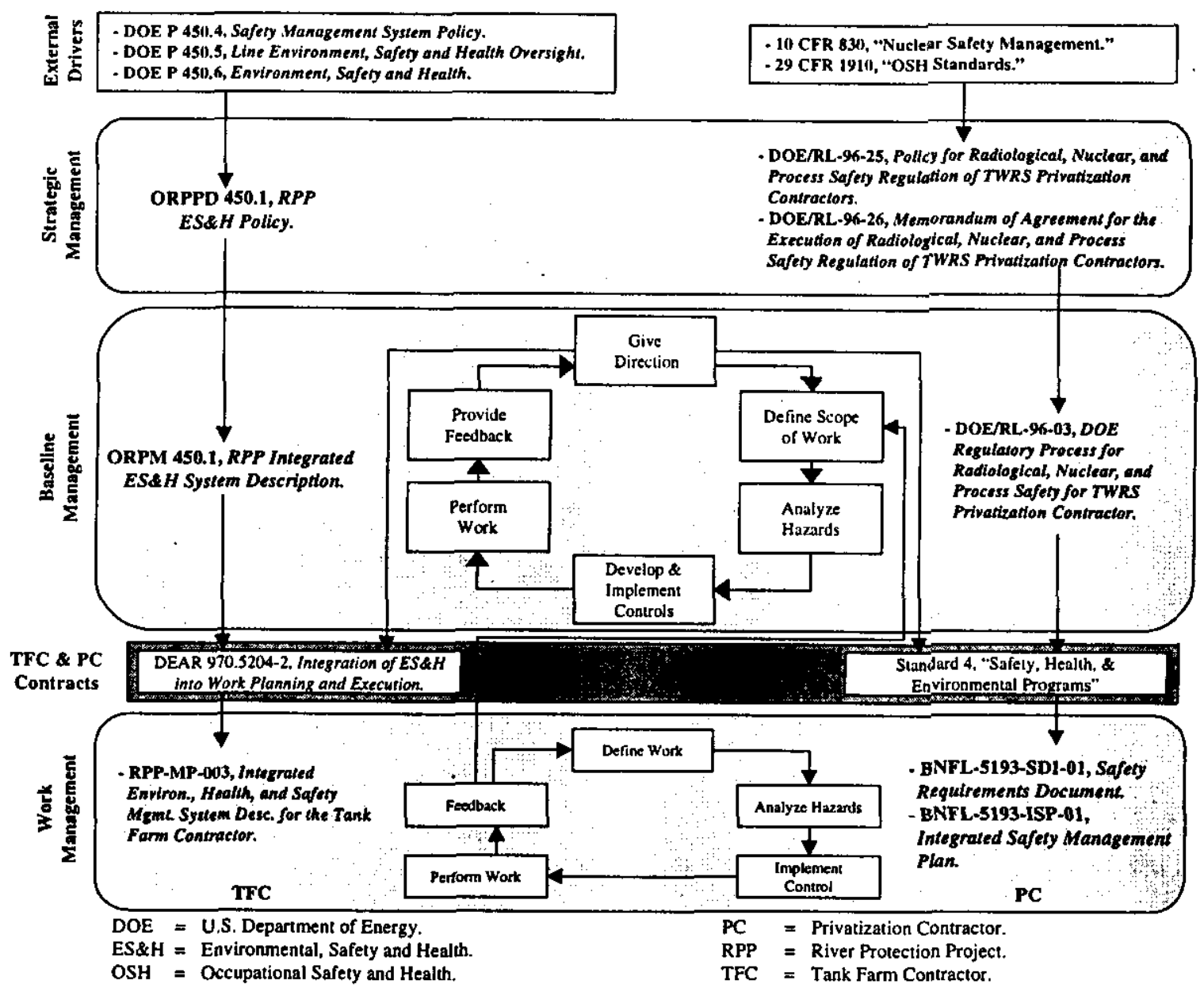

ISM is required in the PC contract through Part I, Section C, Standard 4, "Safety, Health, and Environmental Program." Standard 4 requires the PC to develop an Integrated Safety Management Plan (see BNFL-5193-ISP-01), which is a set of integrated activities directed toward the management or control of radiological, nuclear, and process hazards such that adequate protection is provided to workers, the public, and the environment. The Plan was developed to 29 CFR 1910, "Occupational Safety and Health Standards;" 10 CFR 830, "Nuclear Safety Management;" and DOE/RL-96-03, DOE Regulatory Process for Radiological, Nuclear, and Process Safety for TWRS Privatization Contractors. The RL Regulatory Unit reviewed and approved the Plan, and considers the Plan to be a part of the PC privatization Authorization ; Basis.

The Assistant Manager for Operations has line manager responsibility for operational safety, including ISM implementation. The effectiveness of ISM implementation is measured by tracking the following set of four project-wide performance indicators: (1) total recordable case rate, (2) occupational safety and health cost index, (3) worker radiation dose, and (4) reportable occurrences of releases to the environment. The Assistant Manager for ESH\&Q and staff provide support to the Assistant Manager for Operations and are advocates for ISM. 
DOE/ORP-2000-06

Rev. 0

\subsubsection{Environmental Management}

The RPP and ORP employees and contractors are stewards of the environment, as reflected in ORP policies and all actions the project undertakes. Protection of the environment includes protection of natural, archeological, cultural, and historical resources and public health. The RPP is committed to achieving environmental excellence by systematically integrating ES\&H principles into all aspects of the project work with RPP contractors, RL, and other Hanford Site Prime Contractors. To foster environmental stewardship, the ORP works together with its customer, contractors, regulators, Tribal Nations, stakeholders, and the public to perform the following:

- Consider the impacts of ORP activities on the environment.

- Comply with the Tri-Party Agreement, consent decrees, laws, regulations, permits, and directives.

- Integrate pollution prevention, resource conservation, waste minimization, and environmental impact considerations into planning, decision-making, designs, training, and daily work activities.

- Identify and mitigate existing adverse environmental conditions and anticipate, eliminate, or mitigate future environmental impacts before they pose a threat to the environment, using a risk-based graded approach.

- Promptly report and seek to correct environmental incidents and deficiencies.

- Continually assess performance and implement opportunities to achieve a common goal of environmental excellence.

- Communicate goals, requirements, and progress to employees.

Through the accomplishment of these seven items, the ORP management team and contractors demonstrate stewardship of the environment.

Identification of potential hazards and environmental impacts is a continual process because of the variety of work activities performed within the RPP. The ORP and its contractors identify the environmental impacts of RPP activities through several mechanisms such as National Environmental Policy Act of 1969 documentation, environmental monitoring, spill reporting, chemical-use tracking and reporting, pollution-prevention opportunity assessments, environmental permits, assessments, reports, and waste-generation tracking and reporting. The environmental document architecture that supports environmental management is presented in Figure 6-2, which traces the documents from external drivers to the work management level. 
Figure 6-2. Environmental Document Hierarchy.

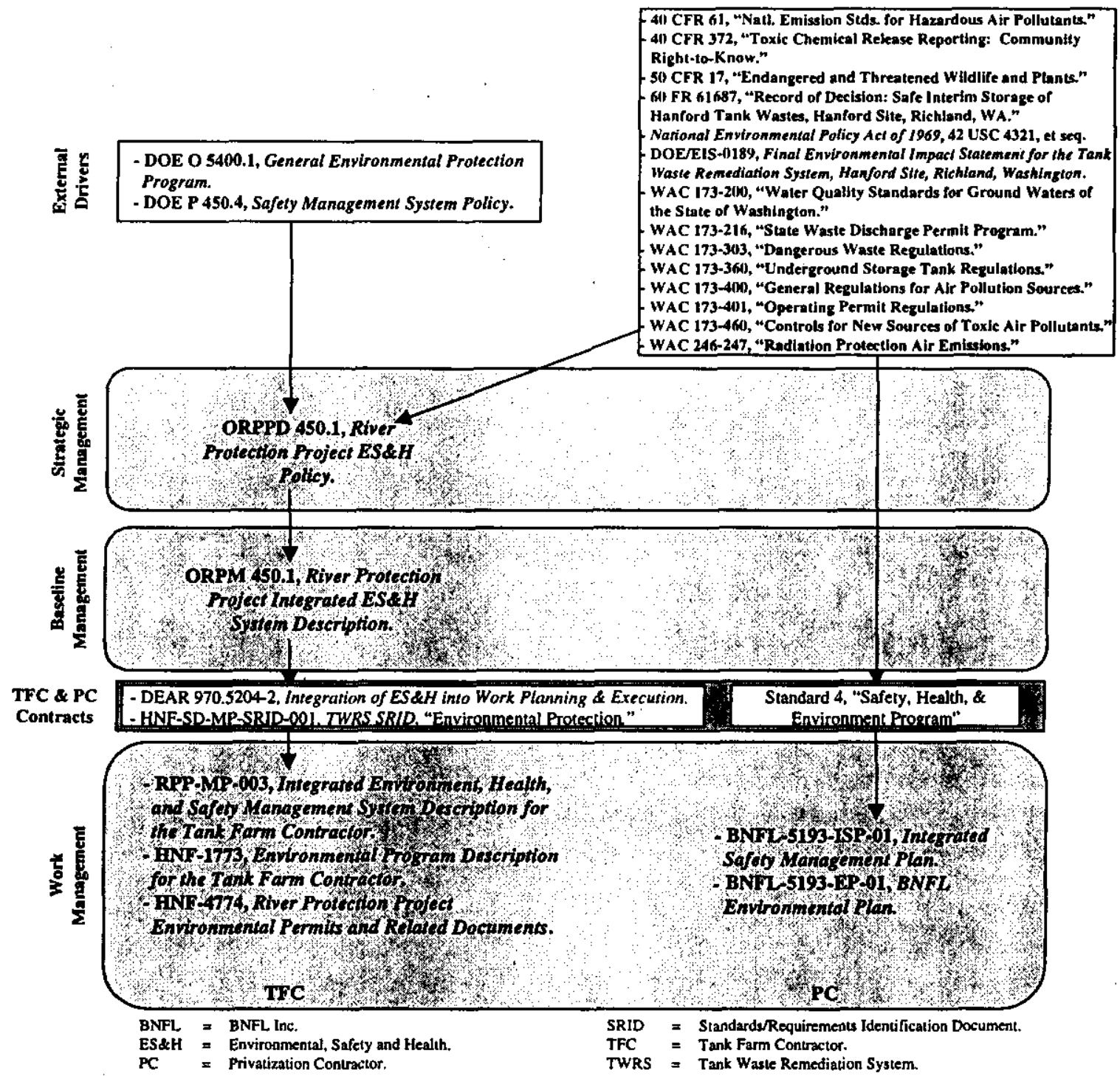

The overall strategy of environmental management is to comply with all applicable environmental laws and regulations during the life cycle of the RPP. Significant environmental drivers include, but are not limited to, the National Environmental Policy Act of 1969, the Tri-Party Agreement; RCRA; the Comprehensive Environmental Response, Compensation, and Liability Act of 1980; the National Historic Preservation Act of 1966; the Clean Air Act of 1955; and the Clean Water Act of 1977. The need to comply with these mandates is clearly stated in the TFC and PC contracts, and the mechanisms to achieve compliance are described in HNF-1773, Environmental Program Description for the Tank Farm Contractor and BNFL-5193-EP-01, Environmental Plan.

The Assistant Manager for ESH\&Q leads the RPP long-range environmental planning process and provides environmental permitting and compliance support. 


\subsubsection{Occupational Safety and Health}

The cornerstone of the RPP's ISM System is the occupational safety and health system. Through the establishment of a strong, systematic occupational safety and health culture, the other aspects of the ISM are implemented more effectively and more easily. The occupational safety and health document architecture is described in Figure 6-3.

Figure 6-3. Occupational Safety and Health Document Hierarchy.

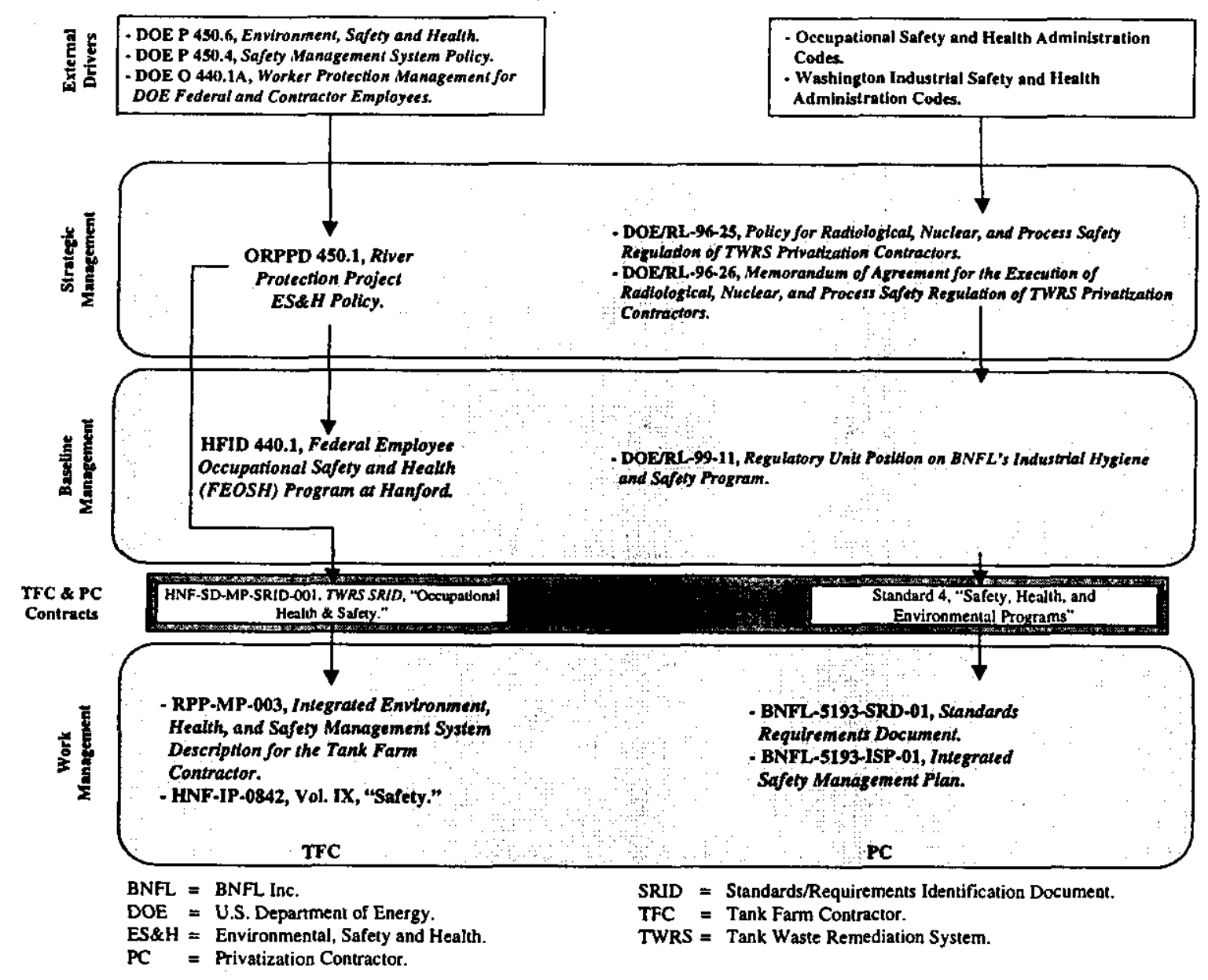

The major external requirement for occupational safety and health for the ORP and the TFC is DOE O 440.1A, Worker Protection Management for DOE Federal and Contractor Employees. This Order establishes the framework for an occupational protection program that will reduce or prevent injuries, illnesses, and accidental losses by providing DOE federal and contractor workers with a safe and healthy workplace. The occupational protection program for federal employees is implemented through HFID 440.1, Federal Employee Occupational Safety and Health (FEOSH) Program at Hanford. This document is applicable to federal employees at the $\mathrm{ORP}$ and RL and designed to ensure a safe and healthy working environment for employees through the establishment of an effective safety and health program. The Assistant Manager for ESH\&Q is responsible for program development, implementation, and oversight of the Federal Employee Occupational Safety and Health Program within the ORP. 
The TFC Worker Safety and Health Program is implemented through RPP-MP-003, Integrated Environment, Health, and Safety Management System Description for the Tank Farm Contractor and HNF-IP-0842, Volume IX, "Safety." These documents describe implementation of the occupational safety and health system in the TFC. One of the key mechanisms to an effective occupational safety and health program is the aspect of worker participation and contribution to the prevention of incidents. The RPP is committed to worker participation and is implementing this mechanism through the adoption of the DOE Voluntary Protection Program. The five tenets of the DOE Voluntary Protection Program are management commitment, employee involvement, hazard identification, hazard control, and safety and health training. The TFC has established an active and aggressive Voluntary Protection Program, which is encouraged by ORPPD 450.1. The Assistant Manager for ESH\&Q oversees the TFC Worker Safety and Health Program.

The PC implements its Occupational Safety and Health Program through BNFL-5193-ISP-01, Integrated Safety Management Plan, which takes a systematic approach to worker safety and health. The program complies with the Occupational Safety and Health Administration codes (29 CFR) and the Washington State codes (Washington Industrial Safety and Health Act of 1973). The system is established with the intent that the Occupational Safety and Health Administration will be the external regulator of occupational safety and health for the privatized Waste Treatment Plant. Currently, the RL Office of Radiological, Nuclear and Process Safety oversees the area of occupational safety and health. The PC is committed to achieving Occupational Safety and Health Act of 1970 Star program status in the Voluntary Protection Program. The PC plans to obtain Star status during construction and operation of the Waste Treatment Plant.

\subsubsection{Nuclear Safety}

The objective of the RPP Nuclear Safety Program is to ensure the nuclear facilities are sited, designed, constructed, operated, decommissioned, and disposed of to adequately protect the public, workers, and the environment from nuclear hazards. This will be accomplished through a systematic and stringent enforcement of nuclear safety and process requirements and an Authorization Basis for operations.

Figure 6-4 identifies nuclear safety documentation and illustrates the hierarchical relationships from the overall policy level to the contractors' internal implementing documents.

The Assistant Manager for ESH\&Q has responsibility for the Nuclear Safety Program within the RPP. Authorization Basis Development, Review, and Approval (ORPID 5480.22-23) establishes the implementing requirements and responsibilities for the ORP Nuclear Safety Program.

The TFC Authorization Basis is the composite of information developed in response to radiological, nuclear, and process safety requirements that are the basis on which the ORP grants permission to perform regulated activities in LMHC-9957211, Contract Number DE-AC06-99RL14047, Authorization Agreement Between U.S. Department of Energy, Office of River Protection and Lockheed Martin Hanford Corporation. The TFC maintains a Nuclear Safety Program that is implemented in the field through HNF-SD-MP-SRID-001, Tank Waste Remediation System Standards/Requirement Identification Document. The TFC's nuclear safety conduct of operation and process is subject to the ORP's independent review. The ORP also 
administers the Price-Anderson Amendments Act of 1988 and 10 CFR 820, "Procedural Rules for DOE Nuclear Facilities" for the TFC.

Figure 6-4. Nuclear Safety Document Hierarchy.

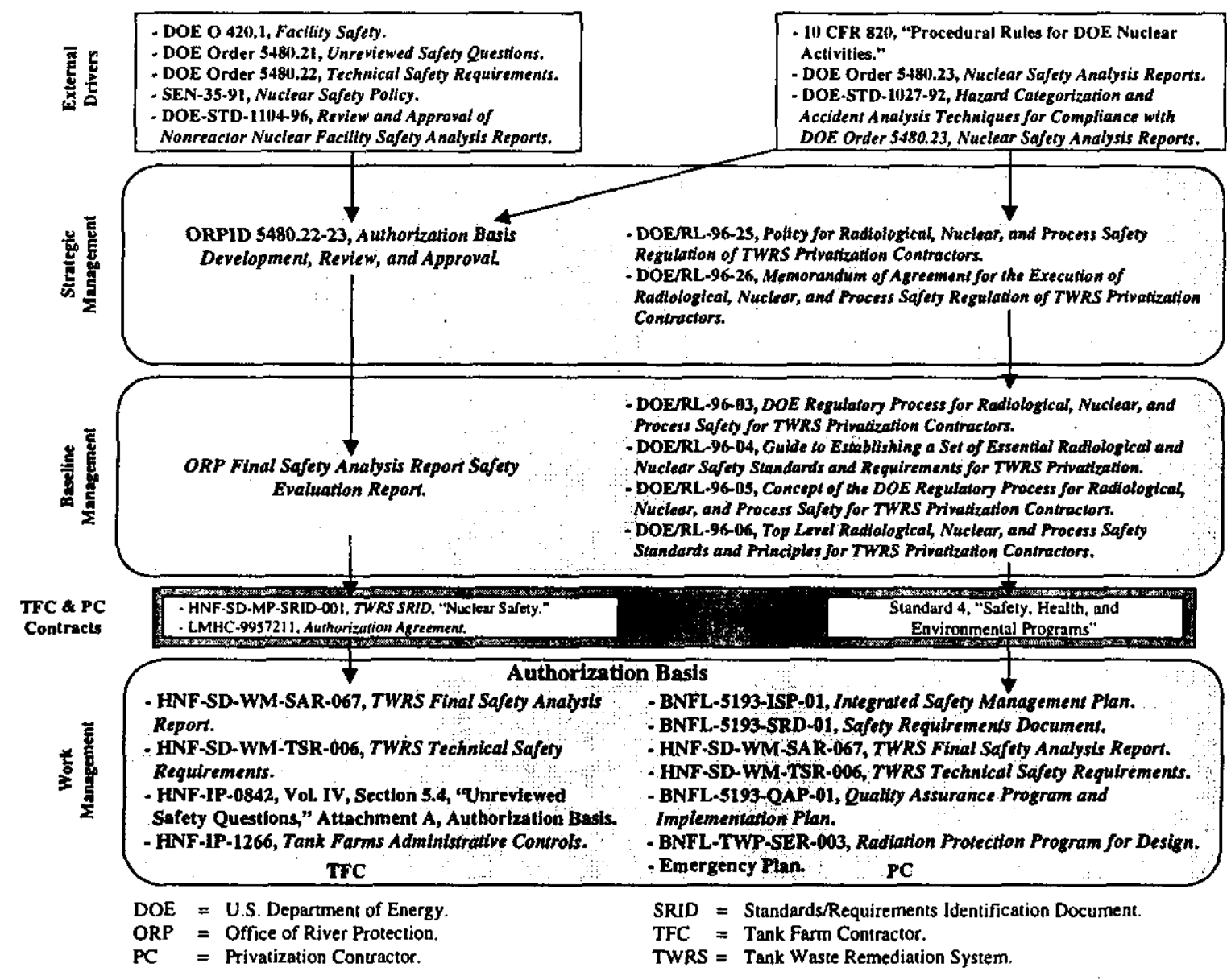

The PC is developing an Authorization Basis as required in its contract (see Standard 4, "Safety, Health, and Environmental Programs"). The Authorization Basis is the composite of information in response to radiological, nuclear, and process safety requirements that are the basis on which the Director of the Regulatory Unit grants permission to perform regulated activities. The Authorization Basis information listed in Figure 6-4 includes that information submitted in connection with a request for Standards Approval, a request for Construction Authorization, or a request for Ojerations Authorization as described in DOE/RL-96-03, DOE Regulatory Process for Radiological, Nuclear, and Process Safety for TWRS Privatization Contractors. The Authorization Basis begins at the Standards Approval regulatory action and continues throughout the design, construction, operation, and deactivation of the PC Waste Treatment Plant. In addition to granting permission to perform regulated activities, the Regulatory Unit also administers the Price-Anderson Amendments Act of 1988 and 10 CFR 820, "Procedural Rules for DOE Nuclear Facilities" for the PC. 
Rev. 0

\subsubsection{Radiological Safety}

The RPP conducts its radiological operations in a manner that ensures radiation exposures to its workers, the public, and the environment are maintained below regulatory limits. In addition, the RPP takes deliberate efforts to reduce exposures and releases to As Low As Reasonably Achievable.

The RPP conduct of operations for radiological safety includes the following:

- Establishment and maintenance of regulatory policy and guidance reflective of national and international radiation protection standards and recommendations

- Training and qualification of personnel who perform radiological work

- Technically competent personnel who implement and oversee the radiological safety programs

- Management involvement and accountability for safe radiological performance

- Accurate radiological measurements, surveys, analyses, worker dose monitoring, and estimates of public exposures are made and recorded

- A comprehensive radioactive materials identification, tracking, and storage system

- Performance of radiological operations to control the spread of radioactive materials

- An As Low As Reasonably Achievable Program and radiological health support operations

- Incorporation of dose reduction, contamination reduction, and waste minimization features into the design of new facilities and significant modifications to existing facilities in the earliest planning stages

- Oversight to ensure that personnel comply with radiological safety requirements and implement and maintain appropriate radiological work practices.

The Assistant Manager for ESH\&Q has responsibility for the Radiation Protection Program within the RPP. The ORP has adopted the RL radiological safety policies, procedures, and manuals where applicable to the RPP.

The applicable radiological requirements are invoked in the TFC and PC contracts and implemented by the respective contractors within their internal conduct of radiological operations processes. Figure 6-5 identifies the radiation safety documentation and illustrates the hierarchical relationships from the overall policy level to the contractors' internal implementing documents. 
DOE/ORP-2000-06

Rev. 0

Figure 6-5. Radiological Safety Document Hierarchy.

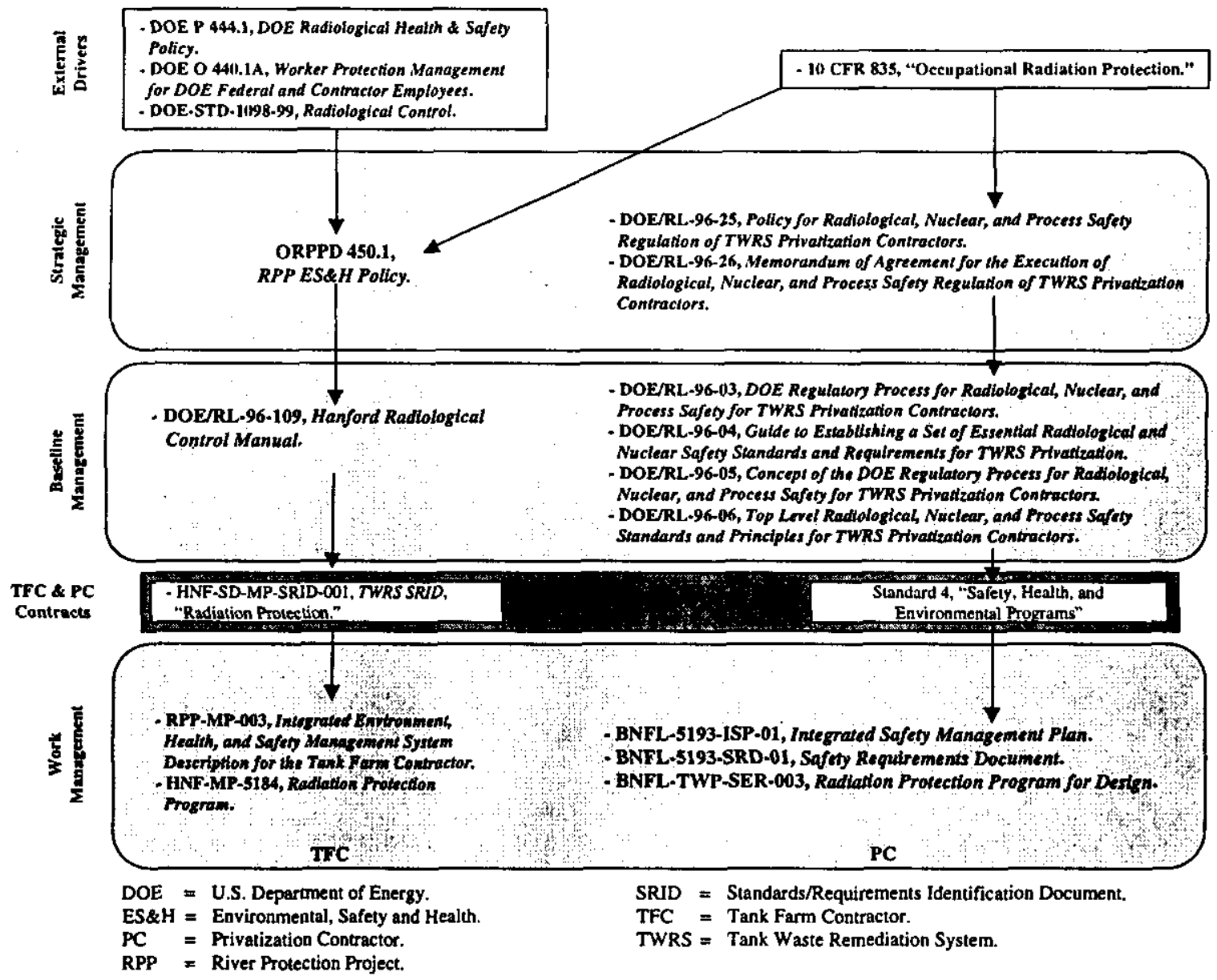

The TFC's radiological conduct of operations and processes are subject to independent safety reviews by the ORP. The TFC conducts self-assessments in accordance with program requirements and applicable $\mathrm{QA}$ policies and procedures.

The PC's radiological program receives oversight from the RL Office of Radiological, Nuclear and Process Safety Regulation. This Office has approved BNFL-TWP-SER-003, Radiation Protection Program for Design. As the PC program develops, the PC Radiation Protection Program for Operations will be developed and approved.

\subsection{QUALITY ASSURANCE}

QA requirements and procedures for the RPP are described in ORPPD 414-1, Quality Assurance Policy and DOE/ORP-2000-08, Quality Assurance Program Description. The Quality Assurance Program Description implements the requirements of DOE Order 414.1A, Quality Assurance; DOE/RW-0333P, Quality Assurance Requirements and Description (QARD); and 10 CFR 830.120, "Quality Assurance Requirements." The Quality Assurance Program Description provides a QA umbrella and process definition for all the RPP quality activities, including tank storage activities, retrieval activities, waste isolation, process design, facility 
design, construction, operations, the products' quality, intermediate products, and secondary waste returned to the DOE by the PC. The Quality Assurance Program Description defines the roles, responsibilities, and relationships of the ORP for quality. It describes the quality processes that flow to the two Prime Contractors and how quality will be managed through the contracts. The QA Program uses a graded approach to accomplish the needs of the RPP while meeting the rigorous requirements of the Quality Assurance Requirements and Description for acceptance of immobilized high-level waste. Figure 6-6 shows the QA hierarchy and relationships.

Figure 6-6. Quality Assurance Document Hierarchy.

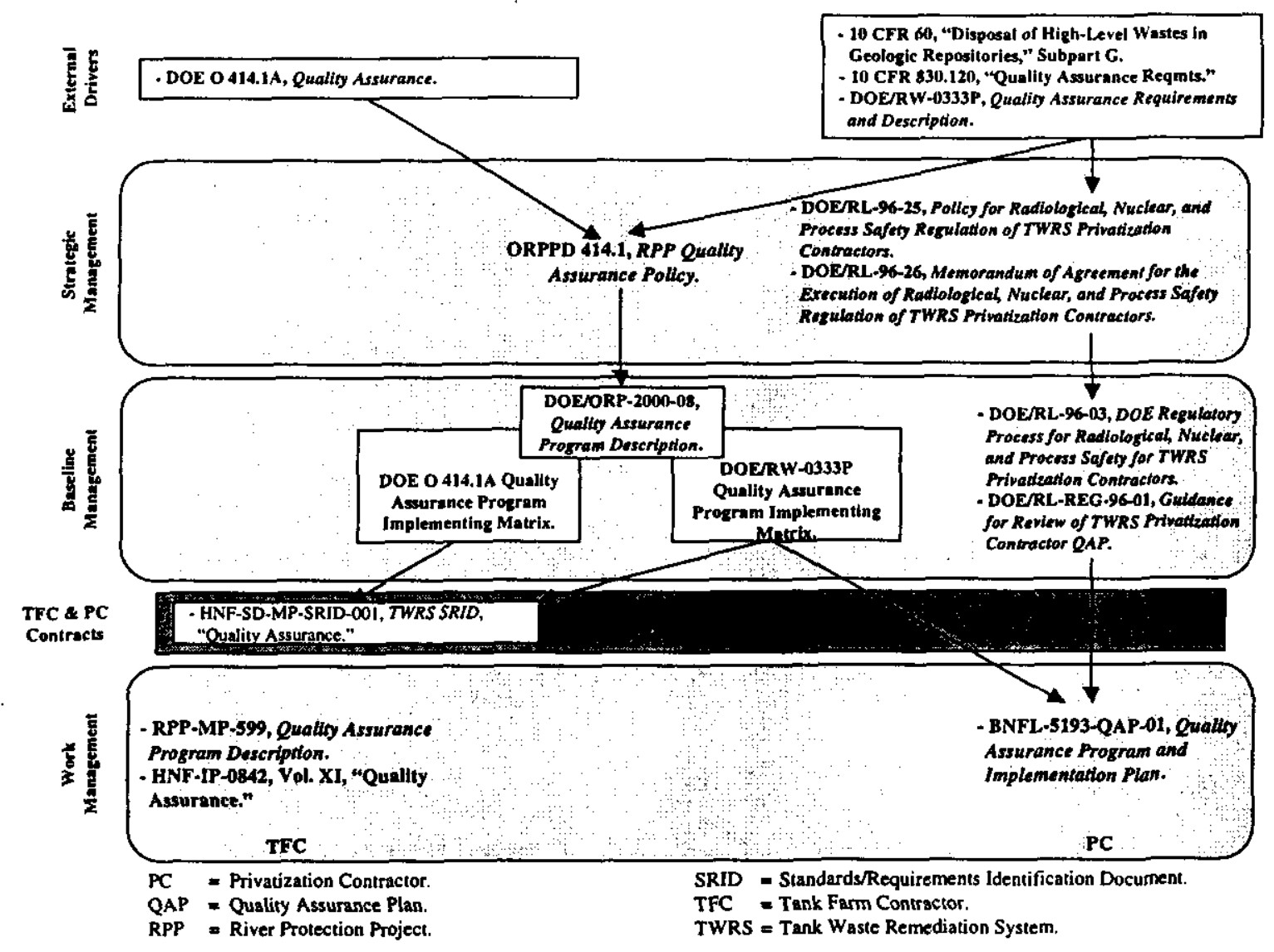

Project QA responsibilities are that of review and oversight of the Quality Assurance Plans (QAP) and activities of the ORP and the contractors. QA activities include the performing activity of achieving quality and the verification activity of ensuring quality. Activities include conducting assessments regarding the effectiveness of QAPs and programs against applicable quality criteria. Activities also include checking, auditing, and surveillance of DOE and contractor activities affecting quality achievement. Specific activities include the following:

- Reviewing contractor-produced technical and QAP documents

- Conducting an annual management assessment (under the direction of senior-level management) of the adequacy and effectiveness of the DOE portion of the QAPs, including planning, procedure adequacy, staffing and organizational structure, 
indoctrination and training, communications and information management, and the adequacy of corrective action

- Conducting annual audits, with participation of DOE-EM-30, of the immobilized high-level waste acceptance activities performed by the contractors under their QAPs

- Conducting periodic, at least annually, audits of the immobilized low-activity waste, intermediate waste, and secondary waste product acceptance activities performed by the contractors under their QAPs

- Performing periodic audits and surveillance of other contractor QAP activities

- Conducting internal audits and surveillance.

The Quality Assurance Program Description requirements are applied to nuclear and non-nuclear facilities and related activities using a graded approach. A graded approach permits application of controls for specific items and activities commensurate with the level of associated risk. That is, application of the graded QA methodology is based on the safety risk, i.e., safety class, safety significant, and general services and project risk (i.e., financial risk, security risk, and legal ramifications of project delay). The graded approach identifies the relevant QA requirement for safety-related structures, systems, and components, and influences the degree and rigor with which the QA requirements are applied.

RPP personnel and activities are required to comply with the Quality Assurance Program Description to the extent the graded approach dictates. Additional facility or project QA program plans can be prepared to cover specific activities that may not be adequately covered by the Quality Assurance Program Description.

The QA requirements and activities applicable to the contractors are established in their contracts and are implemented through the contractors' QAPs. Contractor QAPs are subject to review and concurrence by ORP QA personnel. The Quality Assurance Program Description is reviewed and revised periodically to accommodate changes in requirements, activities, organization changes, or continuous improvement recommendations.

\subsection{EMERGENCY MANAGEMENT}

The RPP emergency management system is designed to function within the Hanford Site emergency management community. Hanford Site community planning partners are RL; DOE contractors; Energy Northwest; U.S. Ecology; the State of Washington; and Benton, Franklin, and Grant Counties. The Hanford Emergency Management Plan (DOE/RL-94-02) defines the Hanford Site plan. The RPP uses DOE/RL-94-02, as illustrated in Figure 6-7. The Hanford Site plan is based on the requirements of 40 CFR 68, "Chemical Accident Prevention Provisions;" 40 CFR 355, "Emergency Planning and Notification;" 29 CFR 1910.38, "Employee Emergency Plans and Fire Prevention Plans" 29 CFR 1910.119, "Process Safety Management of Highly Hazardous Chemicals" WAC 173-303-350, "Contingency Plan and Emergency Procedures" and DOE O 151.1, Comprehensive Emergency Management System. 
Figure 6-7. Emergency Management Document Hierarchy.

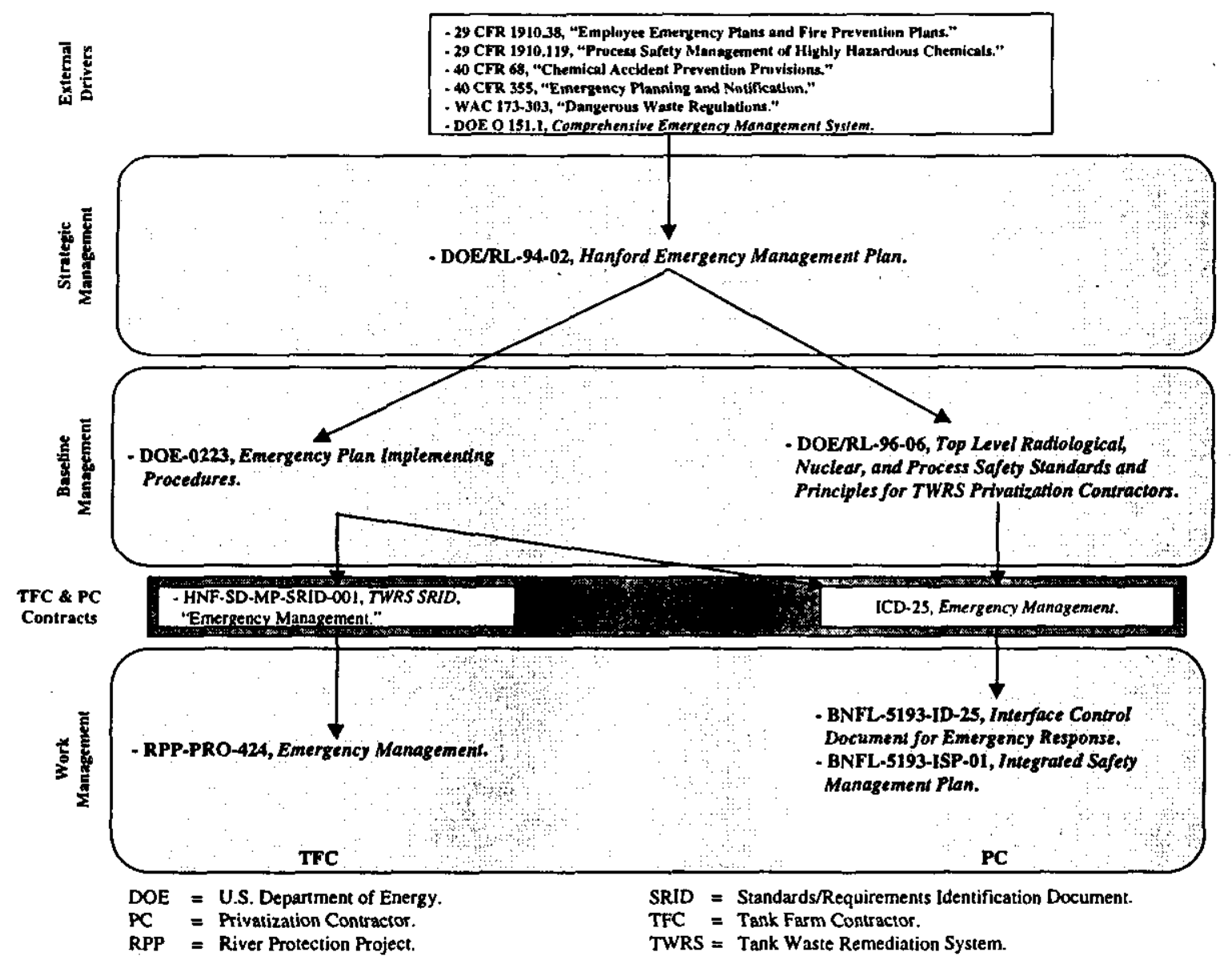

The ORP requires both its Prime Contractors to comply with DOE/RL-94-02, Hanford Emergency Management Plan. The PC also must comply with DOE/RL-96-06, Top Level Radiological, Nuclear, and Process Safety Standards and Principles for TWRS Privatization Contractors. The PC contract also provides for the development of ICD-25, Emergency Management, which is fulfilled by BNFL-5193-ID-25, Interface Control Document for Emergency Response. The document establishes roles and responsibilities between the PC and the DOE on emergency response. The Safety Review Official from the RL Office of Radiological, Nuclear and Process Safety assigns appropriate Regulatory Unit staff to confirm the safety adequacy of the arrangements in the ICD.

The TFC complies with DOE/RL-94-02, Hanford Emergency Management Plan, and conducts Emergency Planning in accordance with RPP-PRO-424, Emergency Management. The ORP oversees emergency management for the TFC.

The Assistant Manager for ESH\&Q coordinates the emergency management and response effort in RPP. Coordination is with the RL Office of Security Emergency Services and the Regulatory Unit. 
Rev. 0

\subsection{SAFEGUARDS AND SECURITY}

Several objectives of the DOE SAS Program are applicable to the RPP. The objectives of the DOE SAS Program are delineated in DOE O 470.1, Safeguards and Security Program. Applicable objectives extracted from this Order are as follows:

- Ensure appropriate levels of protection against unauthorized access, loss or theft of classified matter or government property, and other hostile acts that may cause unacceptable adverse impacts on national security or on the health and safety of DOE and contractor employees, the public, or the environment.

- Provide an integrated system of activities, systems, programs, facilities, and policies for the protection of classified information, nuclear materials, and DOE and certain DOE contractor property and personnel as required by the Atomic Energy Act of 1954, other federal statutes, Executive Orders, and other directives.

- Use RL-HQ-000683, Design Basis Threat for Department of Energy Programs and Facilities, issued by the Director of Security Affairs, in the design and implementation of protection programs.

- Provide levels of protection in a graded manner in accordance with the potential risks.

- Establish SAS programs comparable in effectiveness to other federally regulated programs with similar interests when such levels are consistent with DOE protective needs and national security interests.

- Ensure effective planning of graded protection levels and prudent application of resources.

- Ensure personnel receive training appropriate for their roles in support of the program and those persons given access authorization are aware of SAS Program requirements.

- Standardize SAS equipment and systems to achieve operational and financial benefits.

These objectives are implemented through several Orders, Directives, policies, manuals, and procedures that exist within the ORP and its contractors.

The ORP uses the existing RL SAS organizational and process infrastructure for serving the ORP and the TFC and applies the following for operating its SAS Program: RLID 473.1, Protection of Safeguards and Security Interests; RLID 470.1, Safeguards and Security Corrective Action Management Program; RLID 473.2, Hanford Site Access Eligibility; and RLID 471.2B, Information Security Program. The existing RL infrastructure provides access security, nuclear material tracking systems, information classification and control, and other standardized SAS processes and information systems for Hanford Site usage.

The PC implements the SAS requirements through DOE/RL-96-02, Top-Level Safeguards and Security Requirements for TWRS Privatization and Standard 5, "Safeguards and Security Program," from the PC contract. Additional contract requirements concerning SAS are imposed 
contractually through contract clauses DEAR 952.204-2, "Security Requirements" and FAR 52.237.2, "Protection of Government Buildings, Equipment and Vegetation" (see 48 CFR). Individual contractor policies, plans, and procedures implement the top-level requirements and control the SAS operations at the contractor level.

The point of contact for SAS within RPP is the Assistant Manager for ESH\&Q.

Figure 6-8 shows the SAS document hierarchy.

Figure 6-8. Safeguards and Security Document Hierarchy.

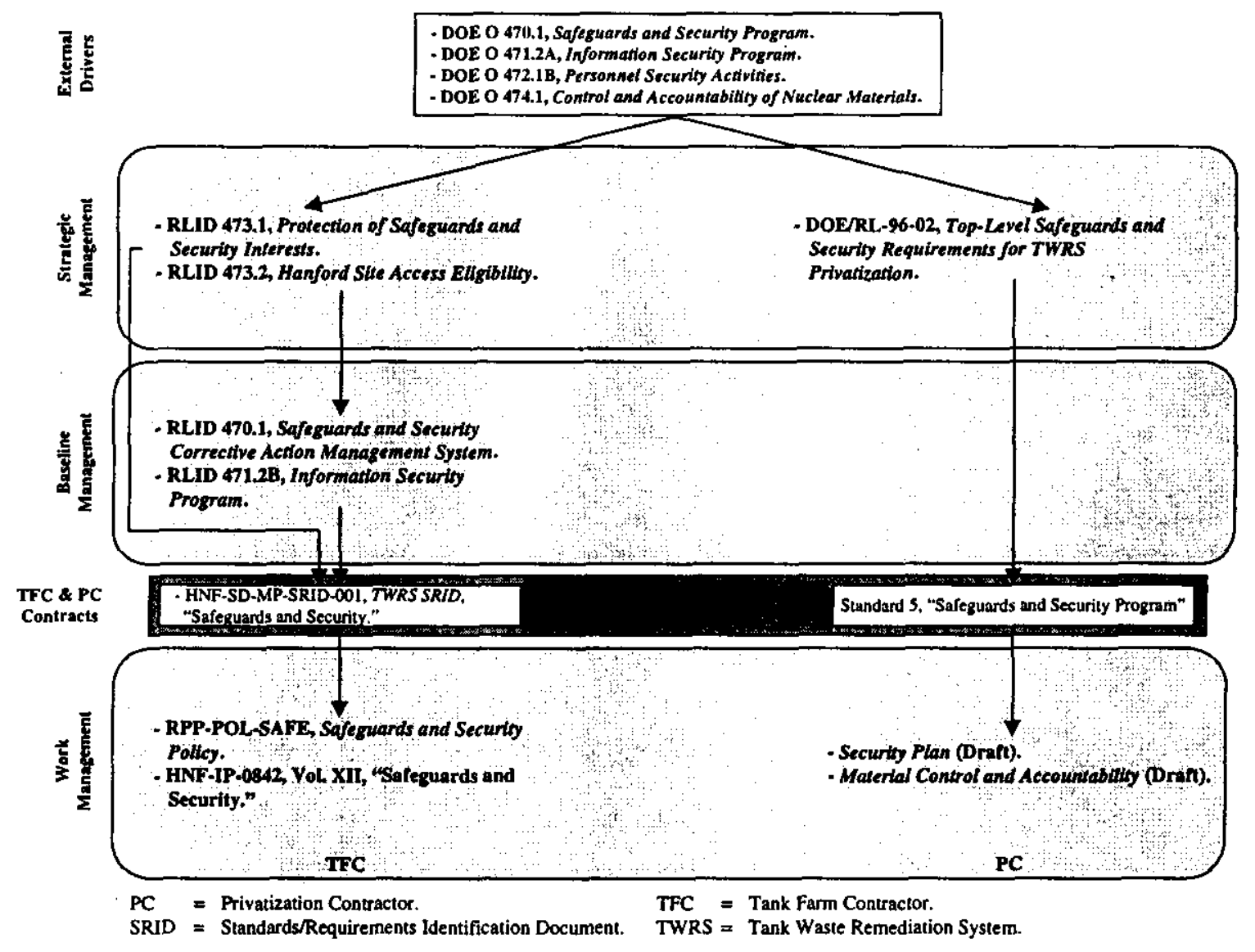


DOE/ORP-2000-06

Rev. 0

This page intentionally left blank. 
DOE/ORP-2000-06

Rev. 0

\subsection{REFERENCES}

Acts

Atomic Energy Act of 1954, as amended, 42 USC 2011 et seq.

Clean Air Act of 1955, as amended, 42 USC 7401 et seq.

Clean Water Act of 1977, as amended, 33 USC 1251 et seq.

Comprehensive Environmental Response, Compensation, and Liability Act of 1980, as amended, 42 USC 9601 et seq.

Government Performance and Results Act of 1993, as amended, Public Law 103-62.

National Environmental Policy Act of 1969, as amended, 42 USC 4321 et seq.

National Historic Preservation Act of 1966, as amended, 16 USC 470 et seq.

Nuclear Waste Policy Act of 1982, as amended, 42 USC 10101 et seq.

Occupational Safety and Health Act of 1970, as amended, 29 USC 651 et seq.

Price-Anderson Amendments Act of 1988, as amended, 42 USC 2010 et seq.

Resource Conservation and Recovery Act of 1976, as amended, 42 USC 6901 et seq.

Strom Thurmond National Defense Authorization Act for Fiscal Year 1999, as amended, Public Law 105-261.

Washington Industrial Safety and Health Act of 1973, as amended, RCW 49.17.

Washington State Hazardous Waste Management Act, as amended, RCW 70.105.

\section{Code of Federal Regulations}

10 CFR 60, "Disposal of High-Level Radioactive Wastes in Geologic Repositories," Code of Federal Regulations, as amended.

10 CFR 820, "Procedural Rules for DOE Nuclear Activities," Code of Fe deral Regulations, as amended.

10 CFR 830, "Nuclear Safety Management," Code of Federal Regulations, as amended.

10 CFR 830.120, "Quality Assurance Requirements," Code of Federal Regulations, as amended.

10 CFR 835, "Occupational Radiation Protection," Code of Federal Regulations, as amended. 
29 CFR 1910, "Occupational Safety and Health Standards," Code of Federal Regulations, as amended.

40 CFR 61, "National Emission Standards for Hazardous Air Pollutants," Code of Federal Regulations, as amended.

40 CFR 68, "Chemical Accident Prevention Provisions," Code of Federal Regulations, as amended.

40 CFR 355, "Emergency Planning and Notification," Code of Federal Regulations, as amended.

40 CFR 372, "Toxic Chemical Release Reporting: Community Right-to-Know," Code of Federal Regulations, as amended.

48 CFR 1-55, "Federal Acquisition Regulations," DEAR 952.204-2, "Security Requirements;" DEAR 970.5204-2, "Integration of Environment, Safety, and Health into Work Planning and Execution;" and FAR 52.237.2, 1984, "Protection of Government Buildings, Equipment and Vegetation," Code of Federal Regulations, as amended.

50 CFR 17, "Endangered and Threatened Wildlife and Plants," Code of Federal Regulations, as amended.

\section{Documents}

DOE/EIS-0189, 1996, 1996, Tank Waste Remediation System, Hanford Site, Richland, Washington, Final Environmental Impact Statement, DOE/EIS-0189, Washington State Department of Ecology, Olympia, Washington, and U.S. Department of Energy, Washington, D.C.

Hanford Federal Facility Agreement and Consent Order, 1996, 2 vols., Washington State Department of Ecology, Olympia, Washington; U.S. Environmental Protection Agency, Washington, D.C.; and U.S. Department of Energy, Washington, D.C.

\section{Federal Register}

60 FR 61687, 1995, "Record of Decision: Safe Interim Storage of Hanford Tank Wastes, Hanford Site, Richland, WA," Federal Register, Vol. 60, pp. 61687-61692 (December 1).

62 FR 8693, 1997, "Record of Decision for the Tank Waste Remediation System, Hanford Site, Richland, WA," Federal Register, Vol. 62, pp. 8'693-8704 (February 26).

\section{Hanford Site Drawings}

Drawing No. TWR-2086, Rev. 2, River Protection Project Level-O Logic (2000).

\section{Privatization Contractor}

BNFL-5193-EP-01, 1998, Environmental Plan, BNFL Inc., Richland, Washington. 
BNFL-5193-ID-01, 2000, Interface Control Document for Raw Water, Rev. 4, as amended, DRAFT, BNFL Inc., Richland, Washington.

BNFL-5193-ID-02, 2000, Interface Control Document for Potable Water, Rev. 4, as amended, DRAFT, BNFL Inc., Richland, Washington.

BNFL-5 193-ID-03, 2000, Interface Control Document for Radioactive Solid Waste, Rev. 5, as amended, DRAFT, BNFL Inc., Richland, Washington.

BNFL-5193-ID-04, 2000, Interface Control Document for Dangerous Waste, Rev. 3d, DRAFT, BNFL Inc., Richland, Washington.

BNFL-5193-ID-05, 2000, Interface Control Document for Nonradioactive, Nondangerous Liquid Effluents, Rev. 4, as amended, DRAFT, BNFL Inc., Richland, Washington.

BNFL-5193-ID-06, 2000, Interface Control Document for Radioactive, Dangerous Liquid Effluents, Rev. 4, as amended, DRAFT, BNFL Inc., Richland, Washington.

BNFL-5193-ID-07, 2000, Interface Control Document for Nondangerous Solid Wastes, Rev. 3d, DRAFT, BNFL Inc., Richland, Washington.

BNFL-5193-ID-08, 2000, Interface Control Document for Liquid Sanitary Wastes, Rev. 3d, DRAFT, BNFL Inc., Richland, Washington.

BNFL-5193-ID-09, 2000, Interface Control Document for Land for Siting, Rev. 4, as amended, Draft, BNFL Inc., Richland, Washington.

BNFL-5193-ID-10, 2000, Interface Control Document for Interfaces for Deactivated Facility and Site, Rev. 3, as amended, Draft, BNFL Inc., Richland, Washington.

BNFL-5193-ID-11, 2000, Interface Control Document for Electricity, Rev. 4, as amended, Draft, BNFL Inc., Richland, Washington.

BNFL-5193-ID-12, 2000, Interface Control Document for Roads, as amended, Rev. 3, Draft, BNFL Inc., Richland, Washington.

BNFL-5193-ID-14, 2000, Interface Control Document for Immobilized High-Level Waste, Rev. 4, as amended, Draft, BNFL Inc., Richland, Washington.

BNFL-5193-ID-15, 2000, Interface Cońtrol Document for Immobilized Low-Activity Waste, Rev. 4, as amended, Draft, BNFL Inc., Richland, Washington.

BNFL-5193-ID-16, 2000, Interface Control Document for Entrained Solids, Rev. 3, Draft, BNFL Inc., Richland, Washington.

BNFL-5193-ID-19, 2000, Interface Control Document for Low-Activity Waste Feed, Rev. 4, as amended, Draft, BNFL Inc., Richland, Washington. 
BNFL-5193-ID-20, 2000, Interface Control Document for High-Level Waste Feed, Rev. 4, as amended, Draft, BNFL Inc., Richland, Washington.

BNFL-5193-ID-21, 2000, Interface Control Document for Waste Feed Tanks, Rev. 3c, DRAFT, BNFL Inc., Richland, Washington.

BNFL-5193-ID-22, 2000, Interface Control Document for Air Emissions, Rev. 4, as amended, Draft, BNFL Inc., Richland, Washington.

BNFL-5193-ID-23, 2000, Interface Control Document for Waste Treatability Samples, Rev. 3, as amended, Draft, BNFL Inc., Richland, Washington.

BNFL-5 193-ID-24, 2000, Interface Control Document for Pretreated Low-Activity Waste, Rev. 3c, DRAFT, BNFL Inc., Richland, Washington.

BNFL-5193-ID-25, 2000, Interface Control Document for Emergency Response, Rev. 3, as amended, Draft, BNFL Inc., Richland, Washington.

BNFL-5193-ID-26, 2000, Interface Control Document for Permitting, Rev. 3, as amended, Draft, BNFL Inc., Richland, Washington.

BNFL-5193-ISP-01, 1998, Integrated Safety Management Plan, Rev. 4, BNFL Inc., Richland, Washington.

BNFL-5193-QAP-01, 1998, Quality Assurance Program and Implementation Plan, Rev. 4, BNFL Inc., Richland, Washington.

BNFL-5193-SDI-01, 1998, Safety Requirements Document, BNFL Inc., Richland, Washington.

BNFL-5193-SRD-01, 1998, Standards Requirements Document, Rev. 2, BNFL Inc., Richland, Washington.

BNFL-TWP-SER-003, 1999, Radiation Protection Program for Design, Rev. 3, BNFL Inc., Richland, Washington.

K60P016, 1999, Change Control, BNFL Inc., Richland, Washington.

K70P030, 2000, Design Change Control, BNFL Inc., Richland, Washington.

PL-W375-PP00001, 1998, Project Engineering Execution Plan, Rev. 0, BNFL Inc., Richland, Washington.

PL-W375-G00002, 1998, Integrated Master Plan, BNFL Inc., Richland, Washington.

PL-W375-MG00001, 1999, River Protection Project - Waste Treatment Plant Project Management Plan, Rev. 1, BNFL Inc., Richland, Washington. 


\section{Standards}

ANSI/EIA-632, 1999, Processes for Engineering a System, American National Standards Institute/Electronic Industries Alliance, Arlington, Virginia.

ANSI/EIA-649, 1998, National Consensus Standard for Configuration Management, American National Standards Institute/Electronic Industries Alliance, Arlington, Virginia.

\section{U.S. Department of Energy}

Department of Energy Acquisition Guide, 1998, September 30, U.S. Department of Energy, Washington, D.C.; www.pr.doe.gov/acqguide.html

DOE/EIS-0222-F, 1999, Final Comprehensive Land-Use Plan Environmental Impact Statement, U.S. Department of Energy, Washington, D.C.

DOE G 120.1-5, 1996, Guidelines for Performance Measurement, U.S. Department of Energy, Washington, D.C.

DOE O 151.1, 1995, Comprehensive Emergency Management System, U.S. Department of Energy, Washington, D.C.

DOE O 224.1, 1997, Contractor Performance-Based Business Management Process, U.S. Department of Energy, Washington, D.C.

DOE O 232.1A, 1997, Occurrence Reporting \& Processing of Operations Management Information, U.S. Department of Energy, Washington, D.C.

DOE O 412.1, 1999, Work Authorization System, U.S. Department of Energy, Washington, D.C.

DOE O 414.1A, 1999, Quality Assurance, U.S. Department of Energy, Washington, D.C.

DOE O 420.1, 1995, Facility Safety, U.S. Department of Energy, Washington, D.C.

DOE O 430.1A, 1998, Life Cycle Asset Management, U.S. Department of Energy, Washington, D.C.

DOE O 435.1, 1999, Radioactive Waste Management, U.S. Department of Energy, Washington, D.C.

DOE O 440.1A, 1998, Worker Protection Management for DOE Federal and Contractor Employees, U.S. Department of Energy, Washington, D.C.

DOE O 470.1, 1995, Safeguards and Security Program, U.S. Department of Energy, Washington, D.C.

DOE O 471.2A, 1997, Information Security Program, U.S. Department of Energy, Washington, D.C. 
DOE/ORP-2000-06

Rev. 0

DOE O 472.1B, 1997, Personnel Security Activities, U.S. Department of Energy, Washington, D.C.

DOE O 474.1, 1999, Control and Accountability of Nuclear Materials, U.S. Department of Energy, Washington, D.C.

DOE O 541.1, 1996, Appointment of Contracting Officers and Contracting Officer Representatives, U.S. Department of Energy, Washington, D.C.

DOE Order 1340.1B, 1993, Management of Public Communications, Publications, and Scientific, Technical, and Engineering Publications, U.S. Department of Energy, Washington, D.C.

DOE Order 5400.1, 1988, General Environmental Protection Program, U.S. Department of Energy, Washington, D.C.

DOE Order 5480.21, 1991, Unreviewed Safety Questions, U.S. Department of Energy, Washington, D.C.

DOE Order 5480.22, 1996, Technical Safety Requirements, U.S. Department of Energy, Washington, D.C.

DOE Order 5480.23, 1994, Nuclear Safety Analysis Reports, U.S. Department of Energy, Washington, D.C.

DOE M 140.1-1A, 1999, Interface with the Defense Nuclear Facilities Safety Board, U.S. Department of Energy, Washington, D.C.

DOE P 444.1, 1996, Department of Energy Radiological Health and Safety Policy, U.S. Department of Energy, Washington, D.C.

DOE P 450.4, 1996, Safety Management System Policy, U.S. Department of Energy, Washington, D.C.

DOE P 450.5, 1997, Line Environment, Safety and Health Oversight, U.S. Department of Energy, Washington, D.C.

DOE P 450.6, 1998, Environment, Safety and Health, U.S. Department of Energy, Washington, D.C.

DOE/PO-0053, 1997, U.S. Department of Energy Strategic Plan, U.S. Department of Energy, Washington, D.C.

DOE/RW-0333P, 1998, Quality Assurance Requirements and Description, U.S. Department of Energy, Washington, D.C.

DOE-STD-1027-92, 1992, Hazard Categorization and Accident Analysis Techniques for Compliance with DOE Order 5480.23, Nuclear Safety Analysis Reports, U.S. Department of Energy, Washington, D.C. 
DOE-STD-1098-99, 1999, Radiological Control, U.S. Department of Energy, Washington, D.C.

DOE-STD-1 104-96, 1996, Review and Approval of Nonreactor Nuclear Facility Safety Analysis Reports, U.S. Department of Energy, Washington, D.C.

EM Privatization Program Management Plan, 1997, U.S. Department of Energy, Washington, D.C.; www.em.doe.gov/private/pmpfin.html

GPG-FM-007, 1996, Risk Analysis and Management, Life Cycle Asset Management, Good Practice Guide, U.S. Department of Energy, Washington, D.C.

GPG-FM-009, 1996, Baseline Change Control, Life Cycle Asset Management, Good Practice Guide, U.S. Department of Energy, Washington, D.C.

GPG-FM-010, 1996, Project Execution and Engineering Management Planning, Life Cycle Asset Management, Good Practice Guide, U.S. Department of Energy, Washington, D.C.

GPG-FM-012, 1996, Configuration and Data Management, Life Cycle Asset Management, Good Practice Guide, U.S. Department of Energy, Washington, D.C.

GPG-FM-016, 1996, Baseline Development, Life Cycle Asset Management, Good Practice Guide, U.S. Department of Energy, Washington, D.C.

Integrated Planning, Accountability, and Budgeting System Handbook, 1999, U.S. Department of Energy, Washington, D.C.; www.em.doe.gov/ipabs/hand.html

Justification of Mission Need, Hanford Site Tank Waste Remediation System to the Energy System Acquisition Advisory Board, 1993, U.S. Department of Energy, Washington, D.C.

Memorandum of Agreement for Acceptance of Department of Energy Spent Nuclear Fuel and High-Level Radioactive Waste Between the Assistant Secretary for Environmental Management (EM), U.S. Department of Energy (DOE), Washington, D.C., and the Director, Office of Civilian Radioactive Waste Management (RW), 1999, Rev. 1, January, U.S. Department of Energy-Headquarters, Washington, D.C.

Memorandum of Agreement Among the Office of Environmental Management, the Richland Operations Office, and the Office of River Protection, 1999, C. Huntoon, K. A. Klein, and R. T. French, August, U.S. Department of Energy-Headquarters, Washington, D.C.

Review and Approval Guidance for Environmental Compliance and Cleanup Agréments for the Office of Environmental Management, 1997, Memorandum to Distribution, June 16, A. L. Alm, Assistant Secretary for Environmental Management, U.S. Department of Energy, Washington, D.C.; www.em.doe.gov/em75/ccamemo.html

RL-HQ-000683, 1996, Design Basis Threat for Department of Energy Programs and Facilities, U.S. Department of Energy, Washington, D.C.

SEN-35-91, 1991, Nuclear Safety Policy, U.S. Department of Energy, Washington, D.C. 
DOE/ORP-2000-06

Rev. 0

\section{U.S. Department of Energy, Office of River Protection}

DE-AC06-RL13308, 1998, Tank Waste Remediation System Privatization Contract,

U.S. Department of Energy, Office of River Protection, Richland, Washington.

DE-AC06-99RL14047, 1999, CH2M HILL Hanford Group, Inc., Contract, U.S. Department of Energy, Office of River Protection, Richland, Washington.

DOE/ORP-99-06, 1999, BNFL Contract Administration Plan, U.S. Department of Energy, Office of River Protection, Richland, Washington.

DOE/ORP-2000-08, 2000, Quality Assurance Program Description, U.S. Department of Energy, Office of River Protection, Richland, Washington.

DOE/ORP-2000-09, 2000, River Protection Project Strategic Plan, U.S. Department of Energy, Office of River Protection, Richland, Washington.

DOE/ORP-2000-10, 2000, River Protection Project Mission Analysis Report, Rev. 0, U.S. Department of Energy, Office of River Protection, Richland, Washington.

DOE/ORP-2000-12, 2000, Office of River Protection Life-Cycle Asset Management Policy, U.S. Department of Energy, Office of River Protection, Richland, Washington.

DOE/ORP-2000-13, 2000, Office of River Protection/Information Resource Management Policy, U.S. Department of Energy, Office of River Protection, Richland, Washington.

DOE/ORP M 411.1-1, 2000, Office of River Protection Functions, Responsibilities, and Authorities Manual (FRAM), U.S. Department of Energy, Office of River Protection, Richland, Washington.

ORP-6126, 2000, RPP Programmatic Risk Management Policy, U.S. Department of Energy, Office of River Protection, Richland, Washington.

ORP-6127, 2000, RPP Programmatic Risk Management Plan, U.S. Department of Energy, Office of River Protection, Richland, Washington.

ORPID 5480.22-23, 2000, Authorization Basis Development, Review, and Approval, U.S. Department of Energy, Office of River Protection, Richland, Washington.

ORPM 450.1, 2000, River Protection Project Integrated Environment, Safety and Health System Description, U.S. Department of Energy, Office of River Protection, Richland, Washington.

ORPPD 414.1, 2000, River Protection Project Quality Assurance Policy, U.S. Department of Energy, Office of River Protection, Richland, Washington.

ORPPD 450.1, 2000, River Protection Project Environment, Safety, and Health Policy, U.S. Department of Energy, Office of River Protection, Richland, Washington. 


\section{DOE/ORP-2000-06}

Rev. 0

RPP-5993, 2000, PIO Administration, U.S. Department of Energy, Office of River Protection, Richland, Washington.

\section{U.S. Department of Energy, Richland Operations Office}

DE-AC06-96RL13200, 1996, Project Hanford Management Contract, U.S. Department of Energy, Richland Operations Office, Richland, Washington.

DOE-0223, 1999, Emergency Plan Implementing Procedures, U.S. Department of Energy, Richland Operations Office, Richland, Washington.

DOE/RL-94-02, 1999, Hanford Emergency Management Plan, Rev. 2, U.S. Department of Energy, Richland Operations Office, Richland, Washington.

DOE/RL-96-02, 1996, Top-Level Safeguards and Security Requirements for TWRS Privatization, U.S. Department of Energy, Richland Operations Office, Richland, Washington.

DOE/RL-96-03, 1996, DOE Regulatory Process for Radiological, Nuclear, and Process Safety for TWRS Privatization Contractors, U.S. Department of Energy, Richland Operations Office, Richland, Washington.

DOE/RL-96-04, 1996, Guide to Establishing a Set of Essential Radiological and Nuclear Safety Standards and Requirements for TWRS Privatization, U.S. Department of Energy, Richland Operations Office, Richland, Washington.

DOE/RL-96-05, 1996, Concept of the DOE Regulatory Process for Radiological, Nuclear, and Process Safety for TWRS Privatization Contractors, U.S. Department of Energy, Richland Operations Office, Richland, Washington.

DOE/RL-96-06, 1996, Top Level Radiological, Nuclear, and Process Safety Standards and Principles for TWRS Privatization Contractors, U.S. Department of Energy, Richland Operations Office, Richland, Washington.

DOE/RL-96-25, 1996, Policy for Radiological, Nuclear, and Process Safety Regulation of TWRS Privatization Contractors, U.S. Department of Energy, Richland Operations Office, Richland, Washington.

DOE/RL-96-26, 1996, Memorandum of Agreement for the Execution of Radiological, Nuclear, and Process Safety Regulation of TWRS Privatization Contractors, U.S. Department of Energy, Richland Operations Office, Richland, Washington.

DOE/RL-96-92, 1996, Hanford Strategic Plan, Rev. 0, U.S. Department of Energy, Richland Operations Office, Richland, Washington.

DOE/RL-96-109, 1999, Hanford Radiological Control Manual, Rev. 2, U.S. Department of Energy, Richland Operations Office, Richland, Washington.

DOE/RL-97-55, 1999, Hanford Site Environmental Management Specification, U.S. Department of Energy, Richland Operations Office, Richland, Washington. 
DOE/ORP-2000-06

Rev. 0

DOE/RL-99-11, 1999, Regulatory. Unit Position on BNFL's Industrial Hygiene and Safety Program, U.S. Department of Energy, Richland Operations Office, Richland, Washington.

DOE/RL-REG-96-01, 1996, Guidance for Review of TWRS Privatization Contractor QAP, U.S. Department of Energy, Richland Operations Office, Richland, Washington.

HFII 440.1, 1999, Federal Employee Occupational Safety and Health (FEOSH) Program at Hanford, U.S. Department of Energy, Richland Operations Office, Richland, Washington.

RLID 470.1, 1997, Safeguards and Security Corrective Action Management System, U.S. Department of Energy, Richland Operations Office, Richland, Washington.

RLID 471.2B, 1999, Information Security Program, U.S. Department of Energy, Richland Operations Office, Richland, Washington.

RLID 473.1, 1996, Protection of Safeguards and Security Interests, U.S. Department of Energy, Richland Operations Office, Richland, Washington.

RLID 473.2, 1997, Hanford Site Access Eligibility, U.S. Department of Energy, Richland Operations Office, Richland, Washington.

RLID 5000.1, 1994, Baseline Execution and Management Process, U.S. Department of Energy, Richland Operations Office, Richland, Washington.

\section{Tank Farm Contractor}

HNF-1773, 2000, Environmental Program Description for the Tank Farm Contractor, Rev. 3, CH2M HILL Hanford Group, Inc., Richland, Washington.

HNF-4774, 2000, River Protection Project Environmental Permits and Related Documents, CH2M HILL Hanford Group, Inc., Richland, Washington.

HNF-EP-0182, 1999, Waste Tank Summary Report, Fluor Hanford, Richland, Washington.

HNF-IP-0842, 2000, RPP Administration, CH2M HLL Hanford Group, Inc., Richland, Washington.

- Volume IV, "Engineering."

- Volume VIII, "Program Administration."

- Volume IX, "Safety."

- Volume XI, "Quality Assurance."

- Volume XII, "Safeguards and Security."

HNF-IP-1266, 1998, Tank Farms Administrative Controls, Fluor Hanford, Richland, Washington. 
HNF-MP-5184, 2000, Radiation Protection Program, Rev. 2, CH2M HILL Hanford Group, Inc., Richland, Washington.

HNF-SD-MP-SRID-001, 1999, Tank Waste Remediation System Standards/Requirements Identification Document, Rev. 2, Lockheed Martin Hanford Corporation, Richland, Washington.

HNF-SD-WM-SAR-067, 2000, Tank Waste Remediation System Final Safety Analysis Report, Rev. 1, as amended, CH2M HILL Hanford Group, Inc., Richland, Washington.

HNF-SD-WM-SEMP-002, 2000, Systems Engineering Management Plan for the Tank Farm Contractor, Rev. 2, CH2M HILL Hanford Group, Inc., Richland, Washington.

HNF-SD-WM-TSR-006, 2000, Tank Waste Remediation System Technical Safety Requirements, Rev. 1, as amended, CH2M HILL Hanford Group, Inc., Richland, Washington.

LMHC-9957211, 1999, Contract Number DE-AC06-99RL14047, Authorization Agreement Between U.S. Department of Energy, Office of River Protection and Lockheed Martin Hanford Corporation, Letter to R. T. French, U.S. Department of Energy, Office of River Protection, October 1, from M. P. DeLozier, Lockheed Martin Hanford Corporation, Richland, Washington.

RPP-5044, 1999, River Protection Project FY 2000 Multi-Year Work Plan, Lockheed Martin Hanford Corporation, Richland, Washington.

RPP-6017, 2000, Draft Project Execution Plan for the Tank Farm Contractor, Rev. 0, CH2M HILL Hanford Group, Inc., Richland, Washington

RPP-MP-003, 2000, Integrated Environment, Health, and Safety Management System Description for the Tank Farm Contractor, Rev. 1, CH2M HLL Hanford Group, Inc., Richland, Washington.

RPP-MP-599, 1999, Quality Assurance Program Description, Rev. 0, CH2M HILL Hanford Group, Inc., Richland, Washington.

RPP-POL-SAFE, 1999, Safeguards and Security Policy, CH2M HILL Hanford Group, Inc., Richland, Washington.

RPP-POL-TRIBES, 1999, Tribes, Regulators, and Stakeholders Participation Policy, CH2M HILL Hanford Group, Inc., Richland, Washington.

RPP-PRO-424, 1999, Emergency Management, CH2M HILL Hanford Group, Inc., Richland, Washington

RPP-PRO-716, 1999, Processing Public Communication Information Products, CH2M HILL Hanford Group, Inc., Richland, Washington 
DOE/ORP-2000-06

Rev. 0

\section{Washington Administrative Code}

WAC 173-200, "Water Quality Standards for Ground Waters of the State of Washington," Washington Administrative Code, as amended.

WAC 173-216, "State Waste Discharge Permit Program," Washington Administrative Code, as amended.

WAC 173-303, "Dangerous Waste Regulations," Washington Administrative Code, as amended.

WAC 173-360, "Underground Storage Tank Regulations," Washington Administrative Code, as amended.

WAC 173-400, "General Regulations for Air Pollution Sources," Washington Administrative Code, as amended.

WAC 173-401, "Operating Permit Regulations," Washington Administrative Code, as amended.

WAC 173-460, "Controls for New Sources of Toxic Air Pollutants," Washington Administrative Code, as amended.

WAC 246-247, "Radiation Protection Air Emissions," Washington Administrative Code, as amended. 
DOE/ORP-2000-06

Rev. 0

\section{DISTRIBUTION}

\section{Onsite}

5

U.S. Department of Energy, Office of Environmental Management

L. B. Fahy

EM-44

M. W. Frei

EM-40

C. L. Huntoon

EM-1 .

T. T. Konopnicki

EM-6

R. G. Lightner

EM-44

1

U.S. Department of Energy, Office of Environmental, Safety and Health

D. M. Michaels EH-1

1

U.S. Department of Energy, Contract Reform \& Privatization Project Office

N. T. Folta

PC-1

Onsite

136

U.S. Department of Energy, Office of River Protection

D. H. Alexander

H6-60

J. J. Bevelacqua

H6-60

N. R. Brown

H6-60

D. C. Bryson

H6-60

D. L. Clark

H6-60

J. M. Clark

H6-60

L. Erickson

H6-60 (6)

K. K. Fick

H6-60

R. T. French

H6-60

L. E. Love

H6-60

J. E. Navarro

H6-60 (112)

B. L. Nicoll ;

H6-60

T. E. Nulty

H6-60

J. A. Poppiti

H6-60

A. B. Sidpara

H6-60

S. D. Stubblebine

H6-60

W. S. Taylor

H6-60

J. D. Voice

H6-60

S. A. Wiegman

H6-60

D. D. Wodrich

H6-60

Distr.-1 
DOE/ORP-2000-06

Rev. 0

U.S. Department of Energy,

Richland Operations Office

H. L. Boston

A7-50

D. C. Gibbs

A4-70

K. A. Klein

A7-50

R. M. Rosselli

A7 -50

Public Reading Room

$\mathrm{H} 2-53$

Bechtel Hanford, Inc.

M. C. Hughes

H0-09

1

BNFL Inc.

S. M. Mackay

H6-60

CH2M HUL Hanford Group, Inc.

D. I. Allen

L. F. Burdge

R2-50

J. G. Cusack

H6-64

W. T. Dehn

R2-58

M. P. Delozier

H6-63

M. D. Ebben

H6-08

A. C. Etheridge

H6-11

J. E. Ferguson

H6-04

C. C. Haass

R2-36

J. O. Honeyman

H6-19

C. R. Hutchins

H6-18

E. E. Mayer

H6-63

M. A. Payne

R2-50

R. E. Raymond

H6-63

W. B. Ross

S7-70

S. E. Seeman

R2-50

T. D. Taylor

H6-18 (10)

D. J. Washenfelder

H6-64

R. D. Wojtasek

H6-18

R2-53

Fluor Hanford

R. D. Hanson

H5-20

Lockheed Martin Services, Inc.

S. R. Nelson

G3-36

Central Files

B1-07

Document Processing Center

A3-94

Distr.-2 
DOE/ORP-2000-06

Rev. 0

Pacific Northwest National Laboratory

H. N. Bowers

R. A. Brouns

K3-66 (10)

P. M. Daling

K9-02

J. H. Holbrook

K8-03

J. K. McClusky

H6-61

G. B. Mellinger

H6-61

T. L. Page

H6-61

J. L. Straalsund

K9-18

Hanford Technical Library

K9-02

P8-55

Distr.-3 
DOE/ORP-2000-06

Rev. 0

This page intentionally left blank.

Distr.-4 